

\section{Estimates of Gains and Losses from Unmeasured Sources and Sinks for Streamflow and Dissolved-Solids Load in Selected Reaches of the Arkansas River, Southeastern Colorado, 2009-2010}

By Roderick F. Ortiz

Prepared in cooperation with the City of Aurora, Colorado Springs Utilities,

Colorado Water Conservation Board, Lower Arkansas Valley Water Conservancy

District, Pueblo Board of Water Works, Southeastern Colorado Water

Conservancy District, and Upper Arkansas Water Conservancy District

Scientific Investigation Report 2012-5252 


\section{U.S. Department of the Interior \\ KEN SALAZAR, Secretary \\ U.S. Geological Survey \\ Marcia K. McNutt, Director}

U.S. Geological Survey, Reston, Virginia: 2013

For more information on the USGS - the Federal source for science about the Earth, its natural and living resources, natural hazards, and the environment, visit http://www.usgs.gov or call 1-888-ASK-USGS.

For an overview of USGS information products, including maps, imagery, and publications, visit http://www.usgs.gov/pubprod

To order this and other USGS information products, visit http://store.usgs.gov

Any use of trade, firm, or product names is for descriptive purposes only and does not imply endorsement by the U.S. Government.

Although this information product, for the most part, is in the public domain, it also may contain copyrighted materials as noted in the text. Permission to reproduce copyrighted items must be secured from the copyright owner.

Suggested citation:

Ortiz, R.F., 2013, Estimates of gains and losses from unmeasured sources and sinks for streamflow and dissolvedsolids load in selected reaches of the Arkansas River, southeastern Colorado, 2009-2010: U.S. Geological Survey Scientific Investigations Report 2012-5252, 53 p. 


\section{Contents}

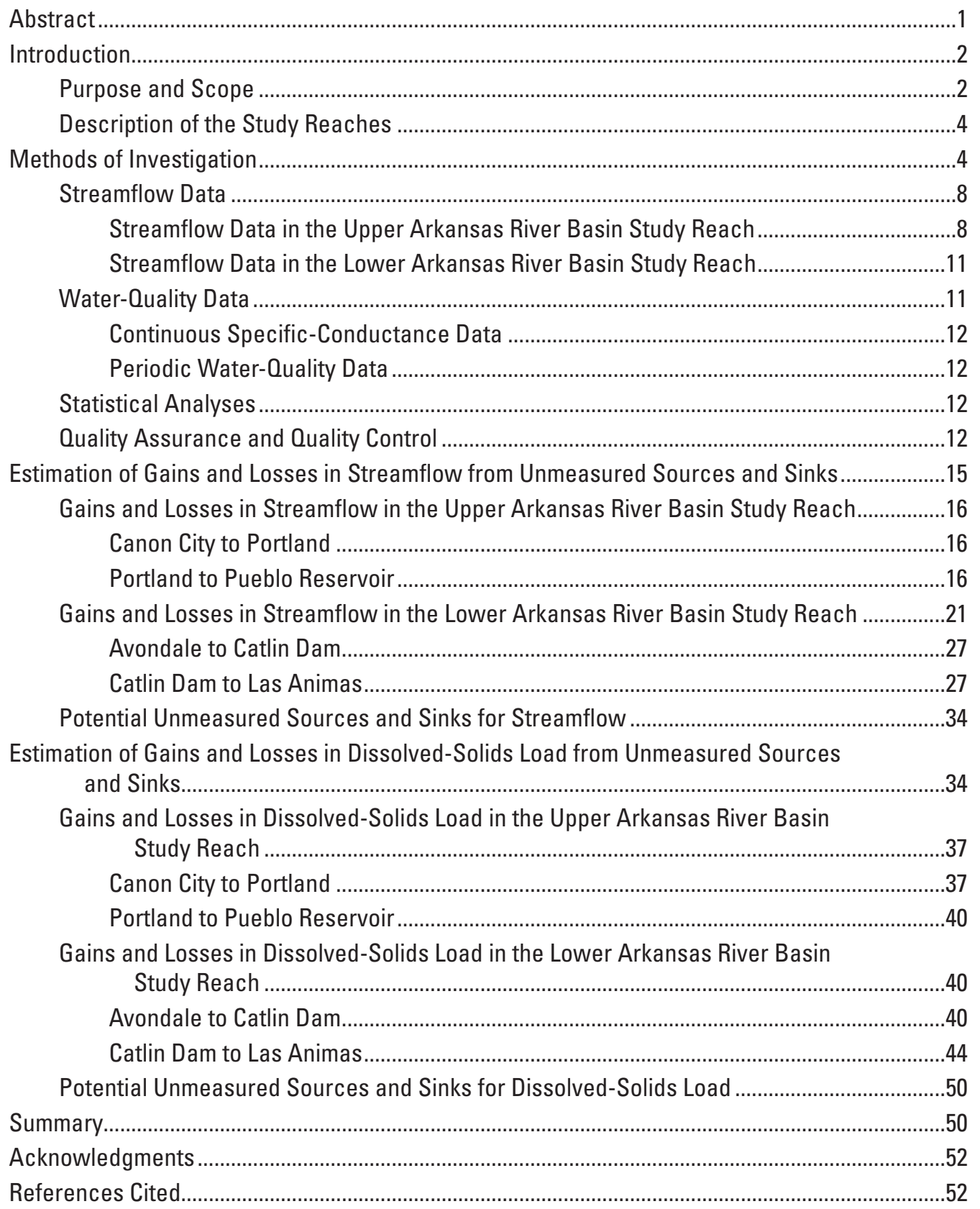




\section{Figures}

1. Location of the Arkansas River Basin in Colorado.

2. Delineation of the Upper Arkansas River study reach showing the location of streamflow and water-quality monitoring sites from Canon City to Pueblo Reservoir, Colorado

3. Delineation of the Lower Arkansas River study reach showing the location of streamflow and water-quality monitoring sites from Avondale to Las Animas, Colorado

4. Annual hydrographs for Arkansas River at Portland (U.S. Geological Survey (USGS) station number 07097000), Arkansas River near Avondale (USGS station number 07109500), and Arkansas River at Las Animas (USGS station number 07124000), Colorado, 2009-2010.

5. (A) Total monthly streamflow and (B) percentage change in total monthly streamflow between Arkansas River at Canon City to Arkansas River at Portland, Colorado, 2009-2010

6. Estimated daily gains and losses from unmeasured streamflow along a subreach of the Upper Arkansas River Basin from Arkansas River at Canon City downstream to Arkansas River near Canon City, Colorado, (A) 2009 and (B) 2010

7. Estimated daily gains and losses from unmeasured streamflow along a subreach of the Upper Arkansas River Basin from Arkansas River near Canon City downstream to Arkansas River at Portland, Colorado, (A) 2009 and (B) 2010

8. Estimated daily gains and losses from unmeasured streamflow along a subreach of the Upper Arkansas River Basin from Arkansas River at Portland downstream to Arkansas River near Portland, Colorado, (A) 2009 and (B) 2010

9. (A) Total monthly streamflow and (B) percentage change in total monthly streamflow from Arkansas River near Avondale to Arkansas River at Catlin Dam, Colorado, 2009-2010.

10. (A) Total monthly streamflow and (B) percentage change in total monthly streamflow from Arkansas River at Catlin Dam to Arkansas River at Las Animas, Colorado, 2009-2010

11. (A) Total monthly streamflow and (B) percentage change in total monthly streamflow from Arkansas River at Catlin Dam to Arkansas River near Rocky Ford, Colorado, 2009-2010

12. (A) Total monthly streamflow and (B) percentage change in total monthly streamflow from Arkansas River near Rocky Ford to Arkansas River at La Junta, Colorado, 2009-2010

13. (A) Total monthly streamflow and (B) percentage change in total monthly streamflow from Arkansas River at La Junta to Arkansas River at Las Animas, Colorado, 2009-2010

14. Estimated daily gains and losses from unmeasured streamflow along a subreach of the Lower Arkansas River Basin from Arkansas River near Avondale downstream to Arkansas River at Nepesta, Colorado, (A) 2009 and (B) 2010

15. Estimated daily gains and losses from unmeasured streamflow along a subreach of the Lower Arkansas River Basin from Arkansas River at Nepesta downstream to Arkansas River at Catlin Dam, Colorado, (A) 2009 and (B) 2010

16. Estimated daily gains and losses from unmeasured streamflow along a subreach of the Lower Arkansas River Basin from Arkansas River at Catlin Dam downstream to Arkansas River near Rocky Ford, Colorado, (A) 2009 and (B) 2010 
17. Estimated daily gains and losses from unmeasured streamflow along a subreach of the Lower Arkansas River Basin from Arkansas River near Rocky Ford downstream to Arkansas River at La Junta, Colorado, (A) 2009 and (B) 2010.

18. Estimated daily gains and losses from unmeasured streamflow along a subreach of the Lower Arkansas River Basin from Arkansas River near Rocky Ford downstream to Arkansas River at Swink, Colorado, (A) 2009 and (B) 2010

19. Estimated daily gains and losses from unmeasured streamflow along a subreach of the Lower Arkansas River Basin from Arkansas River at Swink downstream to Arkansas River at La Junta, Colorado, (A) 2009 and (B) 2010.

20. Estimated daily gains and losses from unmeasured streamflow along a subreach of the Lower Arkansas River Basin from Arkansas River at La Junta downstream to Arkansas River at Las Animas, Colorado, (A) 2009 and (B) 2010.

21. Estimated daily gains and losses in dissolved-solids load along a subreach of the Upper Arkansas River Basin from Arkansas River at Canon City downstream to Arkansas River at Portland, Colorado, (A) 2009 and (B) 2010.

22. Estimated daily gains and losses in dissolved-solids load along a subreach of the Upper Arkansas River Basin from Arkansas River at Canon City downstream to Arkansas River near Canon City, Colorado, (A) 2009 and (B) 2010

23. Estimated daily gains and losses in dissolved-solids load along a subreach of the Upper Arkansas River Basin from Arkansas River near Canon City downstream to Arkansas River at Portland, Colorado, (A) 2009 and (B) 2010.

24. Estimated daily gains and losses in dissolved-solids load along a subreach of the Upper Arkansas River Basin from Arkansas River at Portland downstream to Arkansas River near Portland, Colorado, (A) 2009 and (B) 2010

25. Estimated daily gains and losses in dissolved-solids load along a subreach of the Lower Arkansas River Basin from Arkansas River near Avondale downstream to Arkansas River at Nepesta, Colorado, (A) 2009 and (B) 2010

26. Estimated daily gains and losses in dissolved-solids load along a subreach of the Lower Arkansas River Basin from Arkansas River at Nepesta downstream to Arkansas River at Catlin Dam, Colorado, (A) 2009 and (B) 2010

27. Estimated daily gains and losses in dissolved-solids load along a subreach of the Lower Arkansas River Basin study area from Arkansas River at Catlin Dam downstream to Arkansas River near Rocky Ford, Colorado, (A) 2009 and (B) 2010

28. Estimated daily gains and losses in dissolved-solids load along a subreach of the Lower Arkansas River Basin from Arkansas River near Rocky Ford downstream to Arkansas River at Swink, Colorado, (A) 2009 and (B) 2010

29. Estimated daily gains and losses in dissolved-solids load along a subreach of the Lower Arkansas River Basin from Arkansas River at Swink downstream to Arkansas River at La Junta, Colorado, (A) 2009 and (B) 2010.

30. Estimated daily gains and losses in dissolved-solids load along a subreach of the Lower Arkansas River Basin from Arkansas River at La Junta downstream to Arkansas River at Las Animas, Colorado, (A) 2009 and (B) 2010 


\section{Tables}

1. Site names and station names for the Upper Arkansas River Basin and Lower Arkansas River Basin study reaches in Colorado with available monitoring equipment, 2009-2010

2. Number of specific-conductance measurements and dissolved-solids samples collected at sites in the Upper Arkansas River Basin and Lower Arkansas River Basin study reaches in Colorado, 2009-2010.

3. Estimation of daily specific conductance at selected diversion structures using linear regression equations relating specific conductance at main-stem sites in the Arkansas River Basin in Colorado with data for long-term continuous specificconductance monitors, 2009-2010.

\section{Conversion Factors}

\begin{tabular}{lll}
\hline \multicolumn{1}{c}{ Multiply } & \multicolumn{1}{c}{ By } & \multicolumn{1}{c}{ To obtain } \\
\hline mile $(\mathrm{mi})$ & 1.609 & kilometer $(\mathrm{km})$ \\
cubic foot per second $\left(\mathrm{ft}^{3} / \mathrm{s}\right)$ & 0.02832 & cubic meter per second $\left(\mathrm{m}^{3} / \mathrm{s}\right)$ \\
ton $(2,000 \mathrm{lb})$ & 0.9072 & megagram $(\mathrm{Mg})$ \\
milligram $(\mathrm{mg})$ & 0.00003527 & ounce $(\mathrm{oz})$ \\
liter $(\mathrm{L})$ & 61.02 & cubic inch $\left(\mathrm{in}^{3}\right)$ \\
\hline
\end{tabular}

Temperature in degrees Celsius $\left({ }^{\circ} \mathrm{C}\right)$ may be converted to degrees Fahrenheit $\left({ }^{\circ} \mathrm{F}\right)$ as follows: ${ }^{\circ} \mathrm{F}=\left(1.8 x^{\circ} \mathrm{C}\right)+32$

Temperature in degrees Fahrenheit $\left({ }^{\circ} \mathrm{F}\right)$ may be converted to degrees Celsius $\left({ }^{\circ} \mathrm{C}\right)$ as follows: ${ }^{\circ} \mathrm{C}=\left({ }^{\circ} \mathrm{F}-32\right) / 1.8$

Vertical coordinate information is referenced to the insert datum name (and abbreviation) here, for instance, "North American Vertical Datum of 1988 (NAVD 88)"

Horizontal coordinate information is referenced to the insert datum name (and abbreviation) here, for instance, "North American Datum of 1983 (NAD 83)"

Altitude, as used in this report, refers to distance above the vertical datum.

*Transmissivity: The standard unit for transmissivity is cubic foot per day per square foot times foot of aquifer thickness $\left[\left(\mathrm{ft}^{3} / \mathrm{d}\right) / \mathrm{ft}^{2}\right] \mathrm{ft}$. In this report, the mathematically reduced form, foot squared per day $\left(\mathrm{ft}^{2} / \mathrm{d}\right)$, is used for convenience.

Specific conductance is given in microsiemens per centimeter at 25 degrees Celsius $(\mu \mathrm{S} / \mathrm{cm}$ at $25^{\circ} \mathrm{C}$ ). Concentrations of chemical constituents in water are given either in milligrams per liter $(\mathrm{mg} / \mathrm{L})$ or micrograms per liter $(\mu \mathrm{g} / \mathrm{L})$.

NOTE TO USGS USERS: Use of hectare (ha) as an alternative name for square hectometer $\left(\mathrm{hm}^{2}\right)$ is restricted to the measurement of small land or water areas. Use of liter (L) as a special name for cubic decimeter $\left(\mathrm{dm}^{3}\right)$ is restricted to the measurement of liquids and gases. No prefix other than milli should be used with liter. Metric ton (t) as a name for megagram (Mg) should be restricted to commercial usage, and no prefixes should be used with it. 


\section{Acronyms Used in this Report}

$\begin{array}{ll}\text { ADAPS } & \text { Automated Data Processing System } \\ \text { DS } & \text { Dissolved solids } \\ \text { DWR } & \text { Division of Water Resources } \\ \text { LARB } & \text { Lower Arkansas River Basin } \\ \text { LOWESS } & \text { Locally weighted scatterplot smoothing } \\ \text { NWIS } & \text { National Water Information System } \\ \text { RRPG } & \text { Regional Resource Planning Group } \\ \text { SC } & \text { Specific conductance } \\ \text { UARB } & \text { Upper Arkansas River Basin } \\ \text { USGS } & \text { U.S. Geological Survey }\end{array}$





\title{
Estimates of Gains and Losses from Unmeasured Sources and Sinks for Streamflow and Dissolved-Solids Load in Selected Reaches of the Arkansas River, Southeastern Colorado, 2009-2010
}

\author{
By Roderick F. Ortiz
}

\section{Abstract}

The Arkansas River is an important municipal water supply and is the primary supply for about 400,000 acres of irrigated land in southeastern Colorado. The suitability of this water for domestic, agricultural, and industrial use is affected by high salinity in parts of the Arkansas River. There is a need to quantify mass loading of dissolved solids (DS) in the Arkansas River. In 2009, the U.S. Geological Survey, in cooperation with the Arkansas River Basin Regional Resource Planning Group and the Colorado Water Conservation Board, began a study to estimate gains and losses from unmeasured sources and sinks for streamflow and DS load in selected reaches of the Arkansas River in southeastern Colorado. Two study reaches were selected for investigation - Canon City to just upstream from Pueblo Reservoir (UARB) and Avondale to Las Animas (LARB).

The results from the water-budget analyses indicated that potential areas of unmeasured sources and sinks of streamflow were identifiable in the two study reaches. In the UARB, a substantial volume of water in the subreach from Ark at Canon City to the seasonal gaging station 5 miles downstream (Ark nr Canon City) was unaccounted for by the methodology used in this analysis. The daily gain from unmeasured sources in this subreach was estimated to be about 100 cubic feet per second $\left(\mathrm{ft}^{3} / \mathrm{s}\right)$ or about $20 \mathrm{ft}^{3} / \mathrm{s}$ per river mile. Water-budget estimates for the remaining 18 miles of the UARB study reach indicated that gains or losses from unmeasured sources or sinks were within the measurement error as defined for this report.

In the LARB, gains and losses from unmeasured sources and sinks were identified in some of the subreaches but the magnitude of the flux generally was small. Unmeasured sources ranging from less than 2 to $3 \mathrm{ft}^{3} / \mathrm{s}$ per mile were identified in the river subreaches from Ark at Catlin Dam downstream to Ark at Swink. A streamflow loss was indicated along the subreach from Ark at Nepesta to Ark at Catlin Dam, particularly in 2010. The mechanism and spatial extent of this sink was not identified, and further investigation would be required to better quantify the loss.
The results from the analyses of unmeasured sources of DS load indicated that potential source areas were identifiable in the study areas. It might be expected that unmeasured DS load flux would be identified along the same reaches where unmeasured streamflow flux was identified. To that extent, some of the observed results from the analysis of daily DS loading did mirror the streamflow results. In some subreaches of the Arkansas River, however, unmeasured sources and sinks of DS load did not appear to be directly associated with unmeasured sources and sinks of streamflow.

In the UARB from Ark at Canon City to Ark nr Canon City, unmeasured gains in DS load were estimated to range from 11 to 22 tons per day per mile in 2009 and from about 8 to 13 tons per day per mile in 2010; streamflow from unmeasured sources was estimated to be about $20 \mathrm{ft}^{3} / \mathrm{s}$ per mile along this same reach. Downstream from this short reach, DS load to the river from unmeasured sources was estimated to range from 5.4 to 7.6 tons per day per mile in 2010 for Ark nr Canon City to Ark at Portland and from 11 to 16 tons per day per mile in 2009 for Ark at Portland to Ark nr Portland. Unmeasured gains in streamflow were not identified in either of these subreaches. Several small tributaries with DS concentrations ranging from $3,000 \mathrm{mg} / \mathrm{L}$ to as high as $6,000 \mathrm{mg} / \mathrm{L}$ enter the river along these subreaches. These inputs may indicate a potential source of groundwater that could affect DS loading in the river. Further investigation would be needed to identify the unmeasured source or sources of DS load to determine the nature and extent of unmeasured inputs.

In the LARB, gains in DS load from unmeasured sources were identified for the subreach from Ark nr Avondale to Ark at Nepesta, although no substantial amounts of streamflow from unmeasured sources were identified for this subreach. In 2009 , the estimated gain in DS load from unmeasured sources for this subreach was 4.7 tons per day per mile. An increase in DS load from unmeasured sources also was identified along the subreach of the river from Ark at Catlin to Swink; the DS load from unmeasured sources was estimated to range from 10 to 28 tons per day per mile. The only loss of DS load was 
identified for the subreach from Nepesta to Catlin Dam in 2010. The mechanism and spatial extent of the losses were not identified, and further investigation would be required to better understand the results.

\section{Introduction}

The Arkansas River is an important municipal water supply and is the primary supply for about 400,000 acres of irrigated land in southeastern Colorado. The suitability of this water for domestic, agricultural, and industrial use is affected by high salinity in parts of the Arkansas River. Specific conductance (a surrogate for salinity) in the river increases substantially along the 370 miles downstream from the headwaters to the Colorado-Kansas border (fig. 1). Miller and others (2010) reported that median specificconductance values increased more than 6,000 percent along this reach; much of the increase occurred along the heavily irrigated areas from Canon City to Las Animas. Miles (1977) attributed the increase in salinity to consumptive use of surface water and groundwater by agricultural irrigation. Numerous entities have expressed concerns about a wide range of water-quality issues in the Arkansas River Basin including salinity. Although numerous investigations have documented salinity in the Arkansas River Basin (Cain, 1985; Cain, 1987; Ortiz and others, 1998; Lewis and Brendle, 1998; Miller and others, 2010), few have attempted to quantify and identify potential source loading areas along any reach in the river.

The Arkansas River Basin Regional Resource Planning Group (RRPG) adopted a strategy to address multiple water-quality concerns in the basin (including salinity). To date (2012), the RRPG entities include the City of Aurora, Colorado Springs Utilities, Lower Arkansas Valley Water Conservancy District, Pueblo Board of Water Works, Southeastern Colorado Water Conservancy District, and the Upper Arkansas Water Conservancy District. The overall goals of the strategy include (1) synthesizing electronically available data and studies that could be integrated to help provide a basin-wide understanding of water-quality conditions, (2) identifying and prioritizing water-quality issues within the Arkansas River Basin based on concerns of stakeholders, and (3) identifying gaps in existing data. The U.S. Geological Survey (USGS) is working in cooperation with the RRPG to help address the goals of the strategy. As part of the first goal of the strategy, the USGS has developed, and is maintaining, a water-quality database for selected study areas in Colorado including the Arkansas River Basin. The database combines water-quality data from the USGS National Water Information System (NWIS) and the U.S. Environmental Protection Agency STORET databases; STORET databases include data from many other entities. The interactive repository for the Arkansas River Basin can be accessed online at http://rmgsc. cr.usgs.gov/cwqdr/Arkansas/index.shtml. To help address the second goal of the strategy, Miller and others (2010) described the occurrence and distribution of dissolved solids, selenium, and uranium in groundwater and surface water in the Arkansas River Basin from 1970 through 2009; dissolved solids, selenium, and uranium were identified as constituents of concern by the RRPG. As part of the third goal of the strategy, data-collection activities were conducted in 20092010 to quantify data gaps that were identified in the existing water-quality dataset for the Arkansas River Basin. Ivahnenko and others (2012) used these data to provide an updated characterization of the water quality in selected reaches of the Arkansas River.

Additional information, however, is needed to meet the goals of the strategy. One of the needs is to quantify mass loading of dissolved solids in the Arkansas River. This information would help identify stream reaches where streamaquifer interactions could have a pronounced effect on the water quality in the river, thus providing the RRPG with specific focus areas for further investigation and potential remediation. In 2009, the USGS, in cooperation with the RRPG and the Colorado Water Conservation Board, began a study to estimate gains and losses from unmeasured sources and sinks for streamflow and dissolved-solids load in selected reaches of the Arkansas River in southeastern Colorado. Data were collected during 2009-2010 to provide a basis for estimating the gains or losses for selected reaches from Canon City to Las Animas.

\section{Purpose and Scope}

The purpose of this report is to describe estimates of gains and losses from unmeasured sources and sinks for streamflow and dissolved-solids load in the Arkansas River along two main study reaches in order to help identify subreaches where gains or losses from unmeasured sources and sinks could have a pronounced effect on the water quality in the Arkansas River. Streamflow data collected from established or seasonal (2009-2010) streamflowgaging sites were analyzed to determine a reasonable water budget in selected reaches of the Arkansas River and to identify subreaches where gains or losses in streamflow from unmeasured sources and sinks may be occurring. Specificconductance (SC) and dissolved-solids (DS) data were analyzed to derive estimates of daily DS concentrations at main-stem, tributary, and diversion sites. The results of these two analysis components were combined to derive a massload analysis that was applied at a subreach scale to help identify potential source and sink areas of unmeasured DS loading in the river.

The types of water-quality data needed to assess the dominant physical and chemical processes that result in the existing water-quality conditions were generally unavailable for the study reaches. Data-collection activities by the USGS in 2009-2010 for this study were designed to address these data gaps, thus providing data for an analysis of water budgets and, subsequently, the analysis of mass loading in the Arkansas River. 


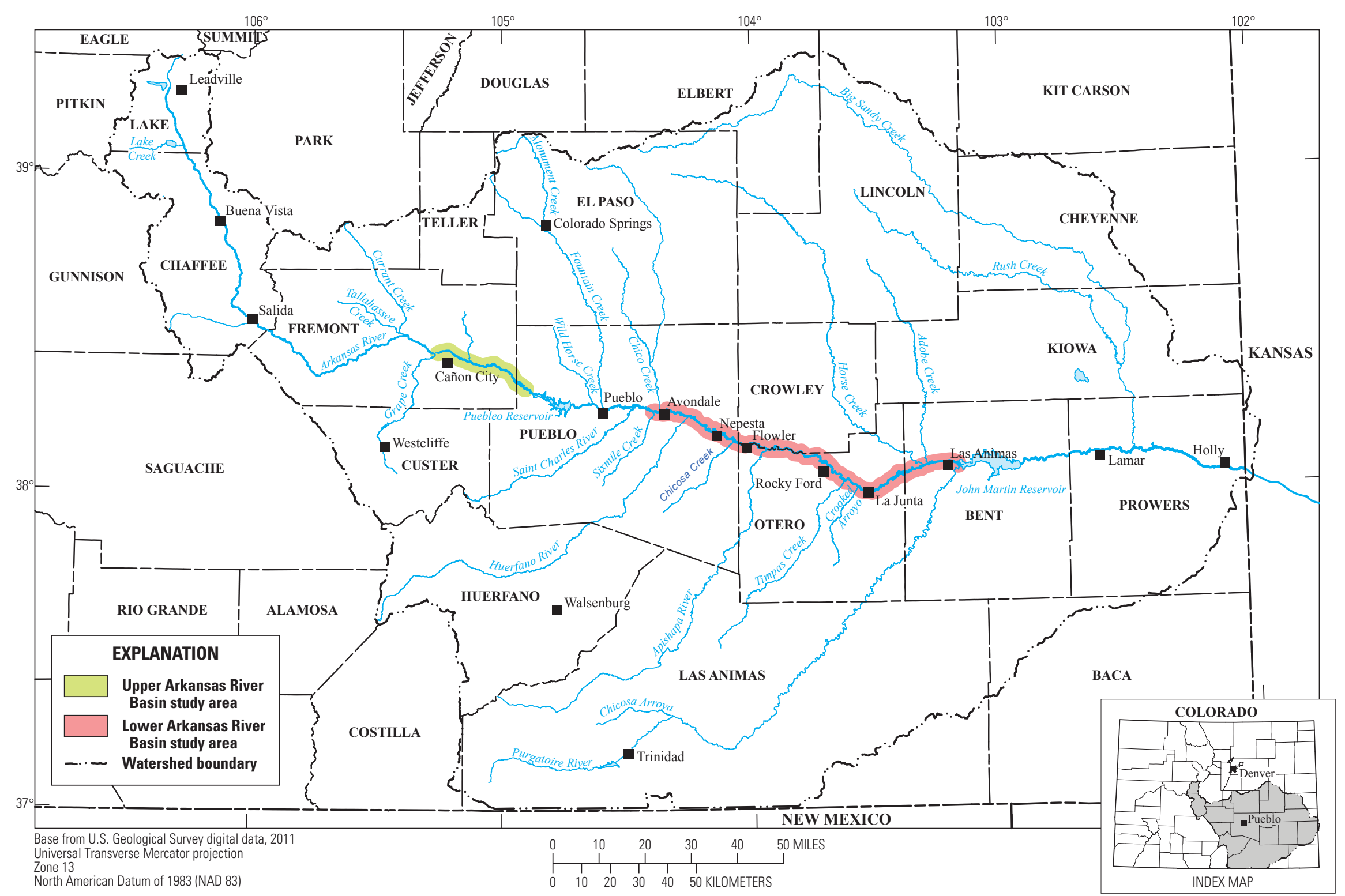

Figure 1. Location of the Arkansas River Basin in Colorado. 
Currently (2012), the existing streamflow network in the Arkansas River Basin provides a framework for the analysis of water budgets and mass loading. The USGS and the State of Colorado operate and maintain numerous streamflow gages on the Arkansas River, at the diversion points of major canals, and near the mouth of major tributaries. However, unmeasured tributary and return flows frequently result in poorly defined water budgets that are the basis for determining source contributions. As such, seasonally operated streamflow gages were installed at selected sites in the Arkansas River and at numerous tributary sites to augment the existing streamflowgaging network in the study reaches.

Periodic measurements of SC and sampling for DS concentrations occurred from May through December of 2009-2010 at numerous main-stem, tributary, and irrigation diversion sites. Existing data collected by other USGS programs also were used as part of this investigation to increase the sample size for regression analysis. Several continuous specific-conductance monitors were installed and operated seasonally at selected locations along the Arkansas River to support existing water-quality monitor sites.

For the purposes of this report, two main study reaches were selected for investigation. The first study reach includes the Arkansas River Basin from Canon City to just upstream from Pueblo Reservoir (fig. 2). This reach is identified as the Upper Arkansas River Basin (UARB) study reach. The second study reach is located downstream from Pueblo Reservoir and includes the Arkansas River Basin from Avondale to Las Animas (fig. 3). This reach is identified as the Lower Arkansas River Basin (LARB) study reach. The use of this naming convention is consistent with the water-quality characterization report by Ivahnenko and others (2012).

\section{Description of the Study Reaches}

The Arkansas River originates among some of the highest peaks in the continental United States and flows from the high-mountain basins onto the plains of southeastern Colorado. The river flows through the UARB and LARB study areas (fig. 1), which contain the UARB and LARB study reaches (figs. 2 and 3). Upstream from Canon City, the Arkansas River is characterized by steep-gradient, highvelocity flows that are confined to a relatively narrow rock and cobble stream channel. The river gradient decreases downstream from Canon City as the river flows generally eastward out of the mountains onto the plains. Pueblo Reservoir is the first main-stem reservoir on the Arkansas River (fig. 1) and controls the release of stored water to the predominantly agricultural river valley from Pueblo downstream to the Colorado-Kansas State line. Water is stored in Pueblo Reservoir as a part of several Federal, State, and municipal programs for a variety of reasons including flood control, irrigation, and public water supply. One program, the Winter-Water Storage Program, allows downstream irrigation-canal companies to store their directflow water in the reservoir for release in the spring or late summer when natural streamflow in the river may not be sufficient for irrigation needs. Under the guidelines of the Winter-Water Storage Program, water is stored in Pueblo Reservoir from November 15 of each year to March 15 of the next year (Southeastern Colorado Water Conservancy District, 2011).

Fountain Creek is a major tributary in the basin and flows into the Arkansas River within the city limits of Pueblo. Fountain Creek is used to convey transmountain return flows from Colorado Springs to the Arkansas River. Expected growth by the City of Colorado Springs could result in larger volumes of wastewater effluent entering Fountain Creek and, ultimately, the Arkansas River (Ortiz, 2004).

Downstream from Fountain Creek, the river channel is a shifting sand channel that meanders along the alluvial flood plain (Miller and others, 2010). For nearly 120 miles downstream from Pueblo Reservoir, water from the river is diverted through a network of irrigation canals and is applied and reapplied to grow crops in the valley. Ultimately, the river flows into John Martin Reservoir near Las Animas (fig. 1); John Martin Reservoir regulates the streamflow for more downstream uses. Storage decreases substantially in both reservoirs by the end of the growing season because of decreased inflow and large downstream demands for irrigation water.

Streamflow in the Arkansas River exhibits considerable seasonal variability (fig. 4). The majority of the total annual streamflow results from snowmelt runoff in the mountains in the western region of the basin. Streamflow is at an annual minimum from October through March and is maintained by natural base flow and main-stem and off-channel reservoir releases. Starting in April, streamflow begins to increase as snow at the lower elevations begins to melt. Maximum streamflow runoff occurs during May and June when the deep snowpack melts at the highest elevations. During July through September, streamflow in the Arkansas River includes decreasing amounts of snowmelt and increased augmentation of stored water from reservoirs. During this period, runoff from intense thunderstorms can substantially increase streamflow in the river for short periods.

\section{Methods of Investigation}

In general, the data collected for this study can be categorized as either streamflow or water quality. Various types of data-collection methods were associated with each of these two categories. The following sections of this report characterize the different types of available streamflow data and water-quality data used as part of the data analysis for this report. Additionally, data-analysis techniques used to characterize and describe the data are provided here. 


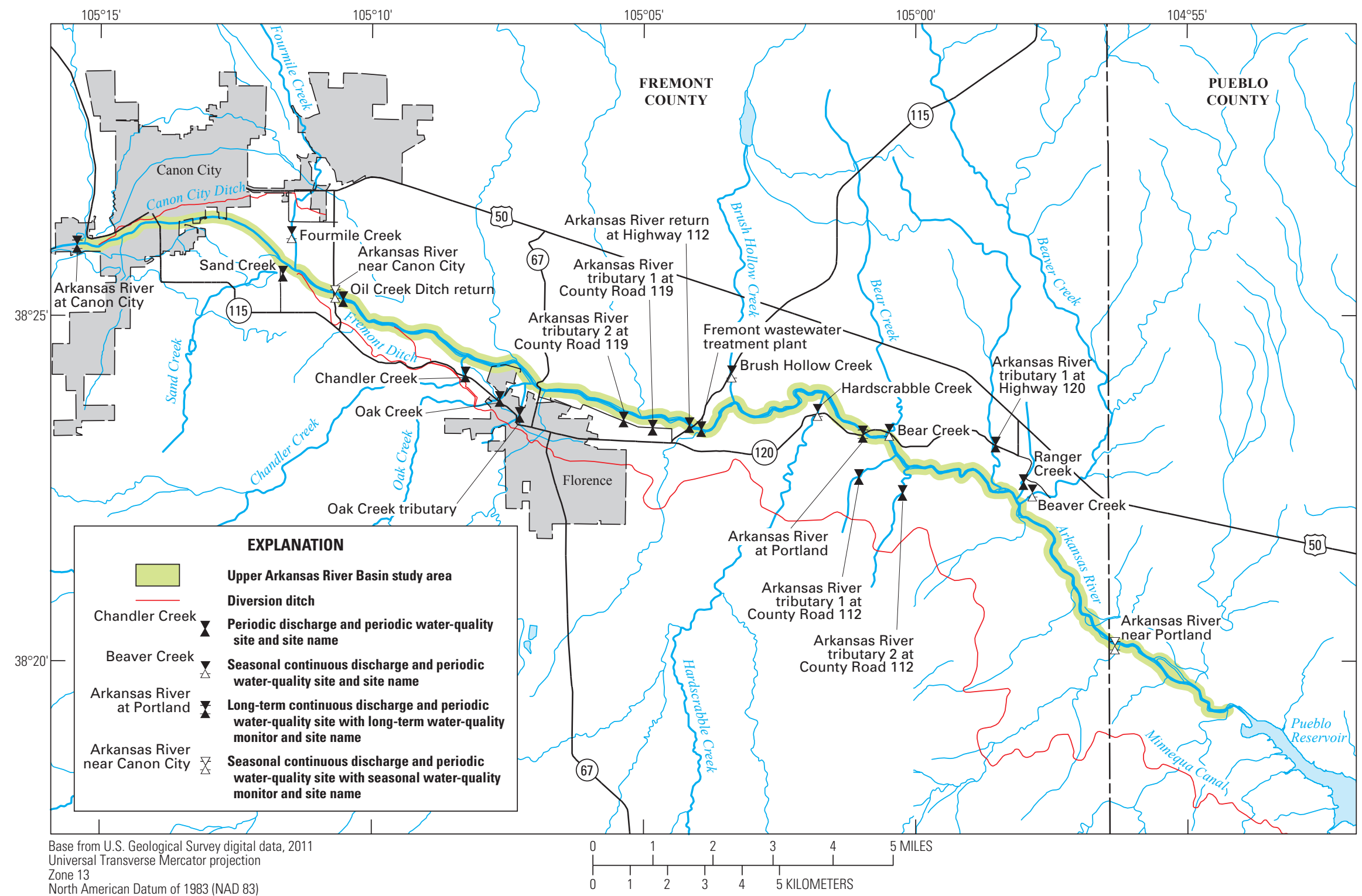

Figure 2. Delineation of the Upper Arkansas River study reach showing the location of streamflow and water-quality monitoring sites from Canon City to Pueblo Reservoir, Colorado. 


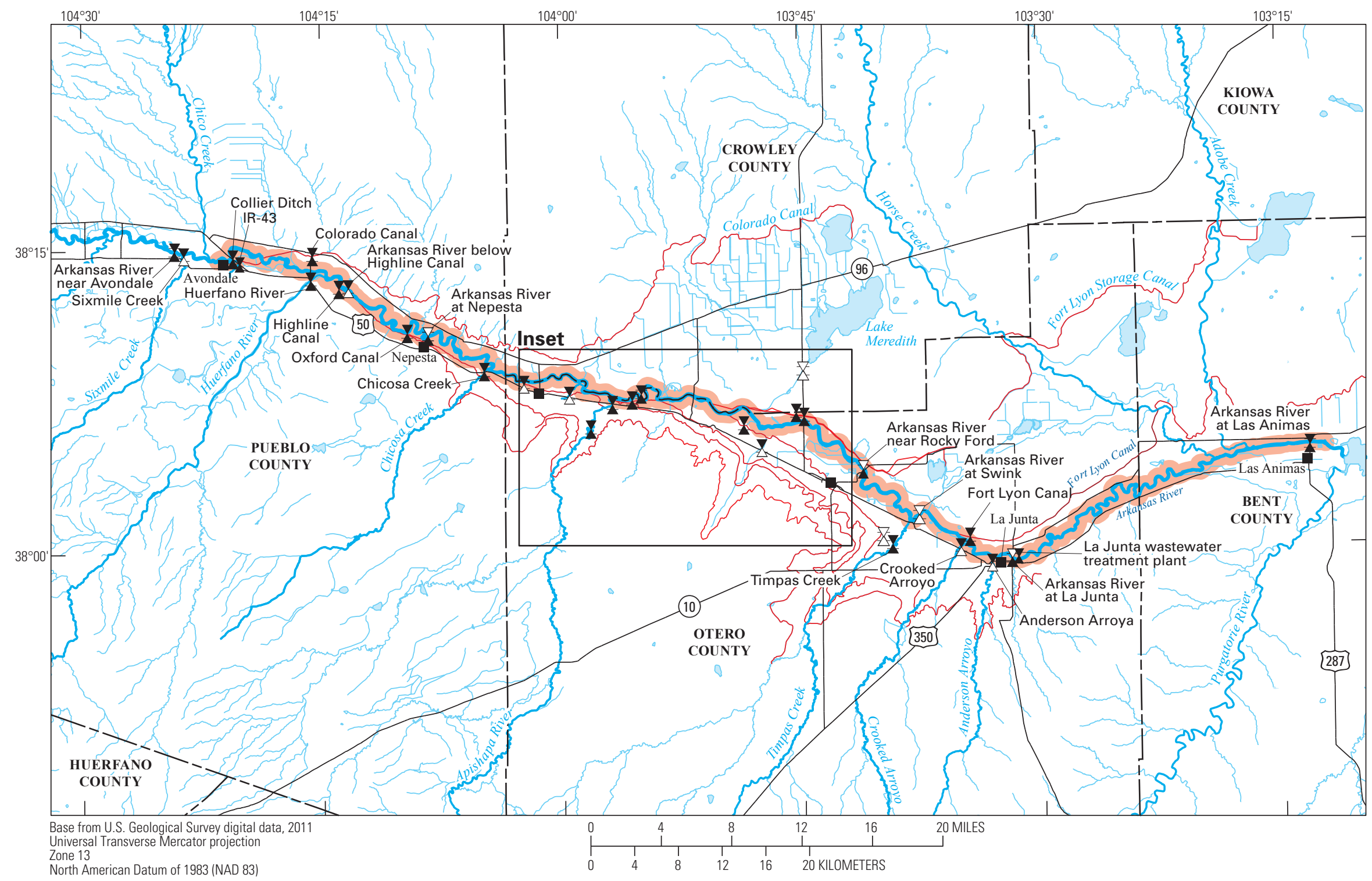

Figure 3 (Inset on following page). Delineation of the Lower Arkansas River study reach showing the location of streamflow and water-quality monitoring sites from Avondale to Las Animas, Colorado. 


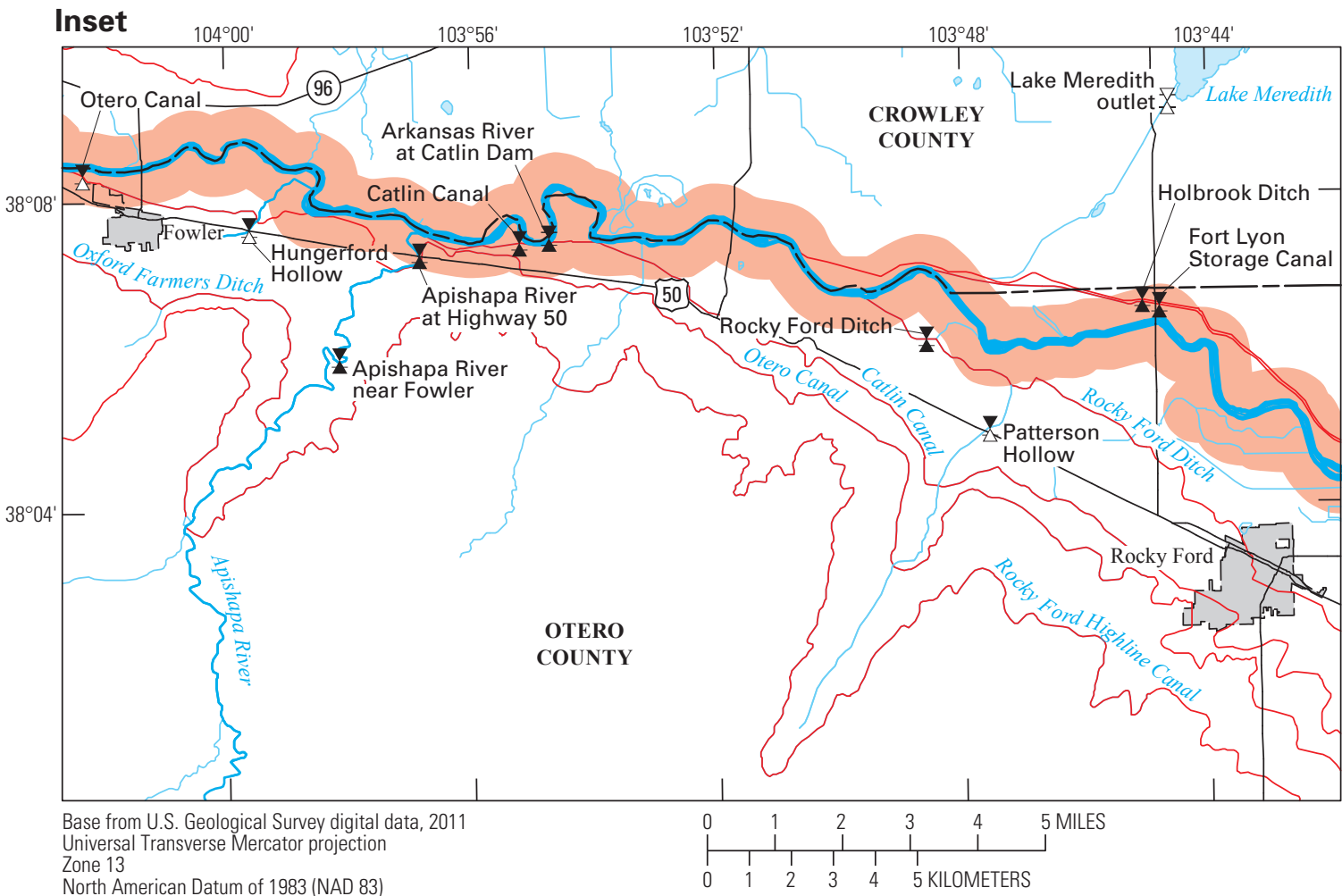

\begin{tabular}{|c|c|}
\hline & EXPLANATION \\
\hline & Lower Arkansas River Basin study area \\
\hline & Diversion ditch \\
\hline${ }^{\mathrm{IR}-43} \mathbf{X}$ & $\begin{array}{l}\text { Periodic discharge and periodic water-quality } \\
\text { site and site name }\end{array}$ \\
\hline Holbrook Ditch $\mathbf{X}$ & $\begin{array}{l}\text { Long-term continuous discharge and periodic } \\
\text { water-quality site and site name }\end{array}$ \\
\hline Paterson Hollow $\nexists$ & $\begin{array}{l}\text { Seasonal continuous discharge and periodic } \\
\text { water-quality site and site name }\end{array}$ \\
\hline $\begin{array}{l}\text { Arkansas River } \\
\text { at Las Animas }\end{array}$ & $\begin{array}{l}\text { Long-term continuous discharge and periodic } \\
\text { water-quality site with long-term water-quality } \\
\text { monitor and site name }\end{array}$ \\
\hline near Nepesta & $\begin{array}{l}\text { Long-term continuous discharge and periodic } \\
\text { water-quality site with seasonal water-quality } \\
\text { monitor and site name }\end{array}$ \\
\hline $\begin{array}{r}\text { Arkansas } \\
\text { at Swink }\end{array}$ & $\begin{array}{l}\text { Seasonal continuous discharge and periodic } \\
\text { water-quality site with seasonal water-quality } \\
\text { monitor and site name }\end{array}$ \\
\hline
\end{tabular}




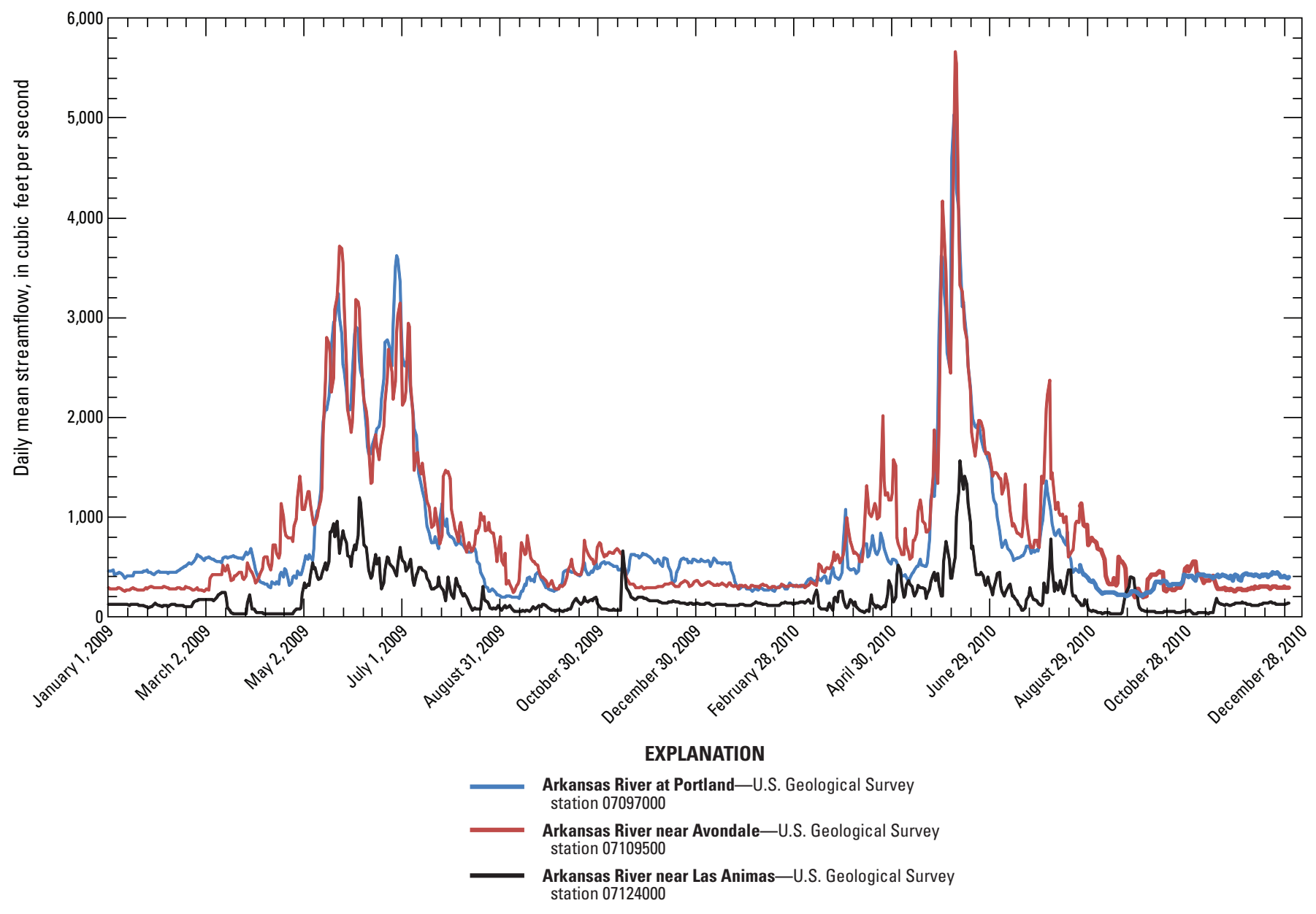

Figure 4. Annual hydrographs for Arkansas River at Portland (U.S. Geological Survey (USGS) station number 07097000), Arkansas River near Avondale (USGS station number 07109500), and Arkansas River at Las Animas (USGS station number 07124000), Colorado, 2009-2010.

\section{Streamflow Data}

Streamflow data analyzed for this report consisted primarily of daily streamflow records retrieved from established long-term streamflow gages or from seasonal gages installed and operated as part of this study. In some instances, where relatively small streamflows were observed, daily values were estimated from available periodic streamflow measurements. Streamflow data from selected wastewater-treatment facilities were provided to the USGS by the plant operators. Typically, daily streamflow data from established gages are published by either the USGS or the State of Colorado Division of Water Resources (DWR) at their individual web sites. The USGS Colorado Water Science Center Web site interface for annual water data reports can be accessed at http://wdr.water.usgs.gov/index. html. The Colorado DWR Web site interface for surfacewater conditions can be accessed at $h t t p: / / w w w . d w r$ state. co.us/SurfaceWater/default.aspx.

\section{Streamflow Data in the Upper Arkansas River Basin Study Reach}

The Colorado DWR operates and maintains two streamflow gages along the UARB study reach of the Arkansas River (table 1 and fig. 2). Monitoring site names herein are those used in table 1. At least 20 years of streamflow data are available for the two gaging sites-Ark at Canon City and Ark at Portland. Generally, daily-mean streamflow (herein referred to as daily streamflow) values were available for all dates during the study period. No established long-term USGS streamflow gages were operational in the UARB study reach; however, seasonal streamflow gages were installed at the monitoring sites Ark nr Canon City and Ark nr Portland (table 1 and fig. 2). Pressure-transducer equipment was installed at each of these sites, and daily streamflow values generally were computed from July-December 2009 and from May-November 2010. Suggested procedures for maintaining records for these seasonal sites are described in Rantz and others (1982a,b). 
Table 1. Site names and station names for the Upper Arkansas River Basin and Lower Arkansas River Basin study reaches in Colorado with available monitoring equipment, 2009-2010.

[USGS, U.S. Geological Survey; MS, main stem; TR, tributary; DV, diversion canal or ditch; WW, wastewater treatment facility; eQgs, existing USGS streamflow station; eQco, existing CODWR streamflow station; sQgs, seasonal USGS streamflow station; user; user supplied streamflow data; eQWgs, existing USGS water-quality station; sQWgs, seasonal USGS water-quality station; WWTP, wastewater treatment plant; --, none available; R, River; Cr, Creek; nr, near; trib, tributary; CR, County Road; BR, Business Road; blw, below; Rd, Road; Hwy, Highway; abv, above]

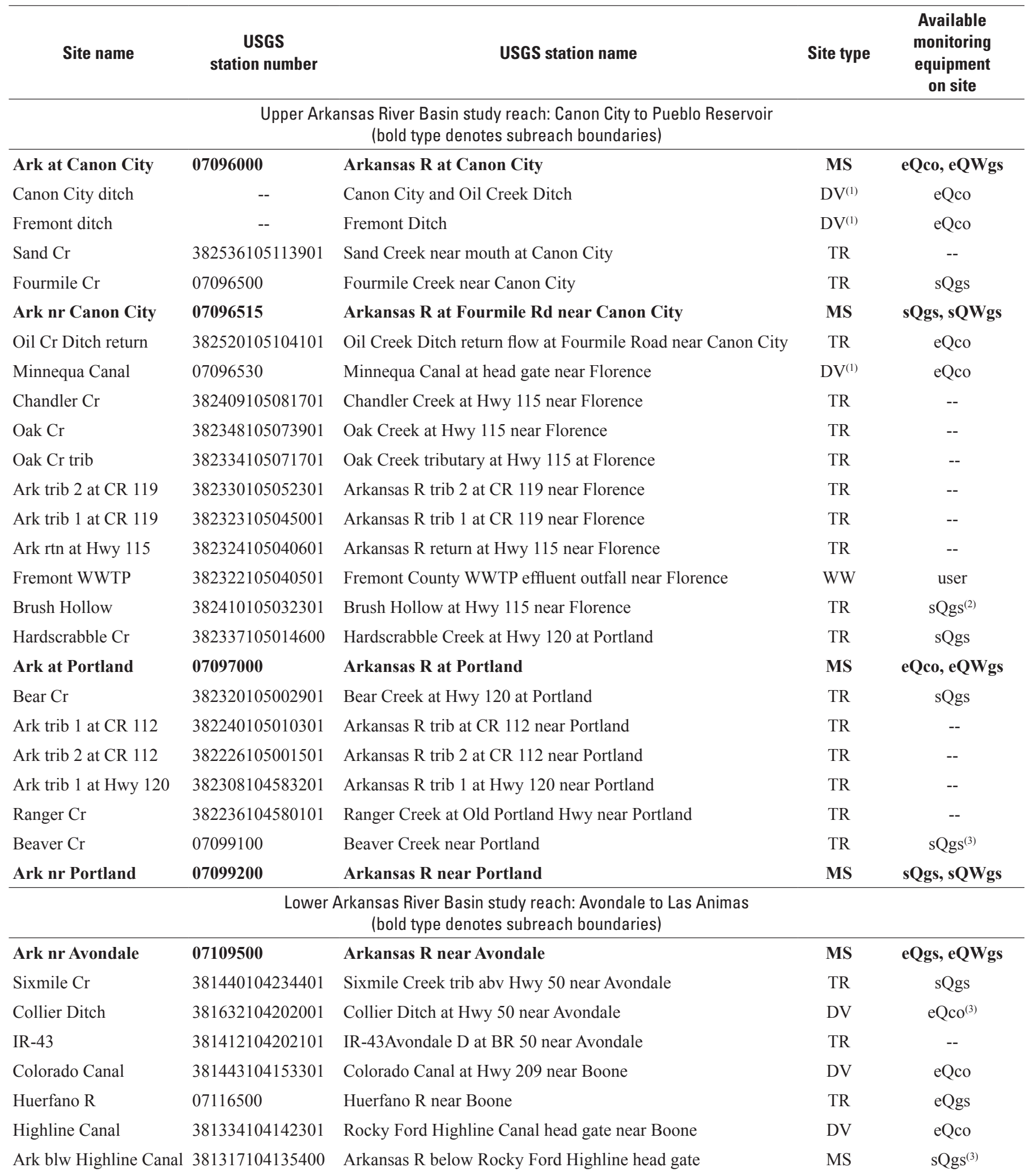


Table 1. Site names and station names for the Upper Arkansas River Basin and Lower Arkansas River Basin study reaches in Colorado with available monitoring equipment, 2009-2010.-Continued

[USGS, U.S. Geological Survey; MS, main stem; TR, tributary; DV, diversion canal or ditch; WW, wastewater treatment facility; eQgs, existing USGS streamflow station; eQco, existing CODWR streamflow station; sQgs, seasonal USGS streamflow station; user; user supplied streamflow data; eQWgs, existing USGS water-quality station; sQWgs, seasonal USGS water-quality station; WWTP, wastewater treatment plant; --, none available; R, River; Cr, Creek; nr, near; trib, tributary; CR, County Road; BR, Business Road; blw, below; Rd, Road; Hwy, Highway; abv, above]

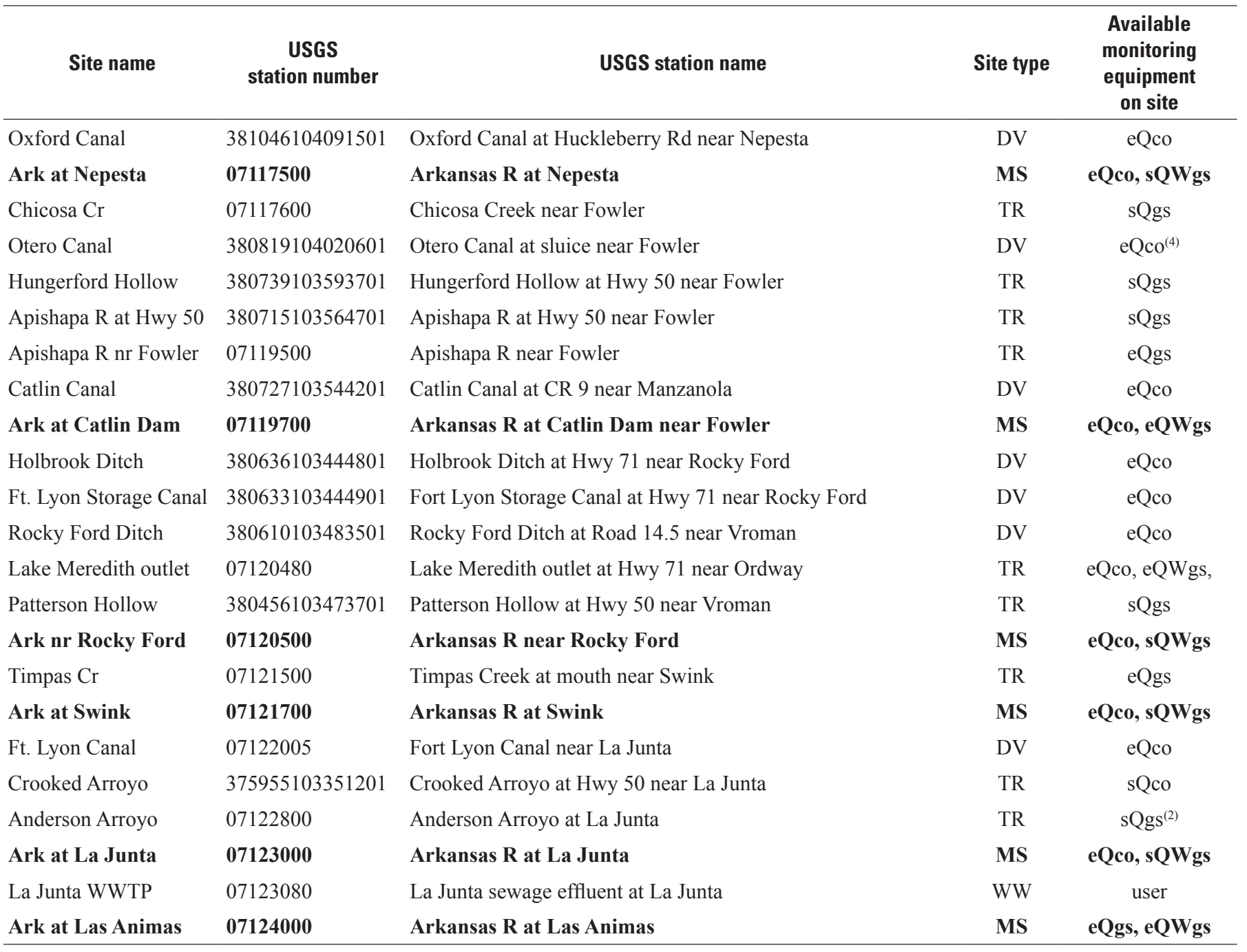

${ }^{1}$ No periodic sampling occurred at this diversion canal or ditch. Water-quality data were estimated from a main-stem site on the Arkansas River given the close proximity of the diversion head gate to a sampled location on the river.

${ }^{2}$ Seasonal streamflow only in 2010 .

${ }^{3}$ Seasonal streamflow only in 2009.

${ }^{4}$ Daily streamflow data provided by Colorado Division of Water Resources Division 2 Water Commissioner, written commun., Aug. 23, 2011). 
No established streamflow gages were operational on any tributary in the UARB during the study period. Historical data, however, were available for Fourmile $\mathrm{Cr}$ and Beaver Cr. Additionally, pressure transducers were installed and operated seasonally at five tributary sites in the UARB to aid in the quantification of inflows to the river during the study period (table 1 ). Seasonal streamflow data were available at Fourmile Cr, Brush Hollow, Hardscrabble Cr, Bear Cr, and Beaver Cr (fig. 2). Generally, daily streamflow for these seasonal sites was computed for a period of record similar to that of the two main-stem sites with two exceptions: Beaver $\mathrm{Cr}$ was only operational in 2009 and Brush Hollow was only operational in 2010. Several other tributaries to the Arkansas River were only measured periodically (table 1). Generally, streamflow from these tributaries was small compared to other tributaries in the study reach and (or) anticipated DS loading to the river was expected to be minimal.

Diversion data from three ditches were analyzed to quantify streamflow diverted from the river during the study period. The Canon City and Fremont ditches divert water near Canon City for irrigation purposes. The Minnequa Canal is a large diversion structure that diverts approximately 53,000 acre-feet of water annually from the Arkansas River for industrial use (fig. 2).

\section{Streamflow Data in the Lower Arkansas River Basin Study Reach}

Two established streamflow gages are operated by the USGS in the LARB study reach from Avondale to Las Animas (table 1 and fig. 3). At least 20 years of streamflow data were available for Ark nr Avondale and Ark at Las Animas. Unitvalue (15-minute record) and daily streamflow data were available for each of these two sites for the study period (2009-2010). One streamflow-gaging site (Ark at Swink) was operated seasonally on the main stem of the river during parts of the study period. A pressure transducer was installed and operated seasonally at Ark at Swink and, generally, daily streamflow at this site was computed for July-December 2009 and May-November 2010. Suggested procedures for maintaining records at the seasonal streamflow-gaging sites are described in Rantz and others (1982a,b).

The Colorado DWR maintains and operates three streamflow gages on the Arkansas River in the LARB (table 1 and fig. 3). The three sites are Ark at Nepesta, Ark nr Rocky Ford, and Ark at La Junta; at least 20 years of daily streamflow data were available for each site. Generally, daily streamflow values were available for all dates during the study period.

Three established streamflow gages on tributaries to the Arkansas River are operated by the USGS. Data from two of the sites, Huerfano R and Timpas Cr, were used directly in the computation of tributary flow to the Arkansas River. Data from the third site, Apishapa R nr Fowler, were used to supplement data at a downstream streamflow gage that was operated seasonally, Apishapa
River at Hwy 50. Seasonal streamflow data were obtained at seven tributary sites in the LARB by installing and operating pressure transducers at each site (table 1 and fig. 3). Seasonal streamflow data were available for Sixmile Cr, Chicosa Cr, Hungerford Hollow, Apishapa R at Hwy 50, Patterson Hollow, Crooked Arroyo, and Anderson Arroyo (fig. 3). Generally, daily streamflow was computed for a period of record similar to that of the main-stem site at Swink with the exception of Anderson Arroyo, which only was operational in 2009. A pressure transducer was not installed at site IR-43 because streamflow was small and anticipated DS loading to the river was minimal. Streamflow measurements were performed periodically at all these sites, as needed, to help determine seasonal streamflow characteristics.

In the LARB, streamflow data were collected by the State of Colorado at 10 diversion sites. Daily diversion streamflow data were available for Collier Ditch, Colorado Canal, Highline Canal, Oxford Canal, Otero Canal, Catlin Canal, Holbrook Ditch, Ft. Lyon Storage Canal, Rocky Ford Ditch, and Ft. Lyon Canal. With the exception of Collier Ditch and Otero Canal, data for all these sites were available from the "Current Streamflow Conditions" Web site maintained by the Colorado DWR at http://www.dwr.state.co.us/ SurfaceWater/default.aspx. Data for these sites were used to quantify diversion flows from the river during the study period (table 1). One reservoir outlet site (Lake Meredith outlet) is operated by the State. Generally, daily streamflow data were available for a period of record when water was being diverted at the head gates.

\section{Water-Quality Data}

The water-quality data used in this report consisted of (1) SC values from continuous-monitoring sites, (2) periodic SC measurements at selected sites, and (3) DS concentrations from water samples collected at numerous sites in the two study reaches. Daily-mean SC data (herein referred to as daily SC) were retrieved from the USGS NWIS database for continuous water-quality monitoring sites (established or seasonal) on the main stem of the Arkansas River. Periodic measurements of SC were available for all sites in both study reaches and were typically paired with DS concentrations. As such, linear regression analyses to estimate DS concentrations from $\mathrm{SC}$ could be performed. All these data were collected as part of a larger sampling effort to assess the water quality in the Arkansas River Basin as described in Ivahnenko and others (2012). Estimated DS concentrations combined with streamflow could then be used to determine DS mass-loading characteristics for the study reaches. The following sections of this report describe the continuous $\mathrm{SC}$ network on the main stem of the Arkansas River and the periodic collection of SC and DS data at main-stem, tributary, and diversion sites including the estimation of DS concentrations through regression techniques. 


\section{Continuous Specific-Conductance Data}

Two established water-quality monitoring sites on the Arkansas River are operated by the USGS in the UARB study reach (table 1 and fig. 2). At least 20 years of daily SC data were available for the sites Ark at Canon City and Ark at Portland. Additionally, two water-quality monitors were installed and operated seasonally on the main stem of the river. Monitors at Ark nr Canon City and Ark nr Portland (table 1 and fig. 2) were operational from July through December 2009 and May through November 2010. Generally, daily SC data for these two sites were available for these dates.

In the LARB, three established water-quality monitoring sites are operated by the USGS on the Arkansas River (fig. 3). At least 20 years of SC data are available for the sites Ark nr Avondale, Ark at Catlin Dam, and Ark at Las Animas. Additionally, one water-quality monitor was installed and operated seasonally on the main stem of the river at Ark at Swink (table 1 and fig. 3). This monitor was operational from July through December 2009 and May through November 2010; daily SC data generally were available for these dates. Continuous SC data also were collected by the USGS downstream from Lake Meredith (fig. 3).

\section{Periodic Water-Quality Data}

Data-collection activities were conducted for 2 years in the two study reaches. In general, water-quality samples were collected from July through December 2009 and May through October 2010. In each study reach, samples were collected periodically to characterize the water quality throughout the various hydrologic conditions observed in the Arkansas River Basin (Ivahnenko and others, 2012). Periodic sampling techniques used established protocols as described in USGS National Field Manual (U.S. Geological Survey, variously dated). Analysis of water samples for the quantification of DS concentrations was performed at the USGS National Water Quality Laboratory in Lakewood, Colo., using approved methods for the determination of DS using residue-onevaporation techniques (Fishman and Friedman, 1989). Data collected in the study area by other USGS water-quality monitoring programs during this time were obtained from the USGS NWIS database and used to supplement spatial and temporal gaps in the data-collection network. Additionally, historical data for selected sites (where available) were used to increase the number of paired SC and DS values used in the regression analyses.

Thirteen water-quality sampling events were conducted from July 2009-October 2010 in the UARB along a reach from Ark at Canon City downstream to Ark nr Portland and in the LARB along a reach from Ark nr Avondale to Ark at Las Animas (Ivahnenko and others, 2012). Sampling events included routine periodic sampling and synoptic sampling using time-of-travel (parcel tracking) techniques. Numerous miscellaneous SC measurements also were recorded at all tributary sites.
Table 2 summarizes the SC and DS data collected for 25 sites in the UARB and for 28 sites in the LARB during the study period.

\section{Statistical Analyses}

Specific conductance has been shown to be highly correlated with DS concentrations in the Arkansas River (Miller and others, 2010; Ortiz and others, 1998). Simple linear regression provides a best straight-line fit between two variables (one independent and one dependent variable) to obtain a predictive equation. Ivahnenko and others (2012) provided simple linear-regression relations between instantaneous SC (the independent variable) and DS (the dependent variable) values using paired data measured at selected surface-water sites in the two study reaches from July 2009 through November 2010. For this report, the regressions described by Ivahnenko and others (2012) were used to estimate daily DS concentrations from measured daily or instantaneous SC values at most main-stem and tributary sites; additional historical paired data were used in selected instances to increase the number of comparisons for regression (table 2).

Locally weighted scatterplot smoothing (LOWESS) techniques were used to evaluate gains or losses from unmeasured sources and sinks in daily streamflow and estimated daily DS load for selected sites in the Arkansas River. Originally developed by Cleveland (1979) and further developed by Cleveland and Devlin (1988), LOWESS specifically denotes a method that is more descriptively known as locally weighted polynomial regression. The smoothing technique describes the relation, in this instance, between streamflow and time or between DS and time without assuming linearity or normality of the residuals (Helsel and Hirsch, 1992). At each point in the dataset, a low-degree polynomial is fit to a subset of the data with explanatory variable values near the point whose response is being estimated. The polynomial is fit using weighted least-squares regression, giving more weight to points near the point whose response is being estimated and less weight to points further away. The value of the regression function for the point is then obtained by evaluating the local polynomial using the explanatory variable values for that data point. The LOWESS fit is complete after regression-function values have been computed for each of the data points in question.

\section{Quality Assurance and Quality Control}

Streamflow and water-quality data collected as part of this report were varied with respect to their quantity and quality. All of the data were reviewed using appropriate methodologies and (or) procedures as required by the USGS or the State of Colorado. In general, these data can be accessed through the World Wide Web as described previously in this report. 
Table 2. Number of specific-conductance measurements and dissolved-solids samples collected at sites in the Upper Arkansas River Basin and Lower Arkansas River Basin study reaches in Colorado, 2009-2010.

[SC, specific conductance; DS, dissolved solids; MS, main stem; DV, diversion canal or ditch; TR, tributary; WW, wastewater treatment plant; --, no data available]

\begin{tabular}{|c|c|c|c|c|c|}
\hline Site name & Site type & $\begin{array}{c}\text { Number of } \\
\text { periodic SC } \\
\text { values available } \\
2009-2010\end{array}$ & $\begin{array}{c}\text { Number of } \\
\text { periodic DS } \\
\text { values available } \\
2009-2010\end{array}$ & $\begin{array}{c}\text { Number of } \\
\text { paired } \\
\text { SC and DS } \\
\text { values used } \\
\text { in analysis }\end{array}$ & $\begin{array}{l}\text { Were historical } \\
\text { (1990-2008) } \\
\text { SC and DS data } \\
\text { used as part of } \\
\text { data analysis? }\end{array}$ \\
\hline
\end{tabular}

Upper Arkansas River Basin study reach: Canon City to Pueblo Reservoir (in downstream order)

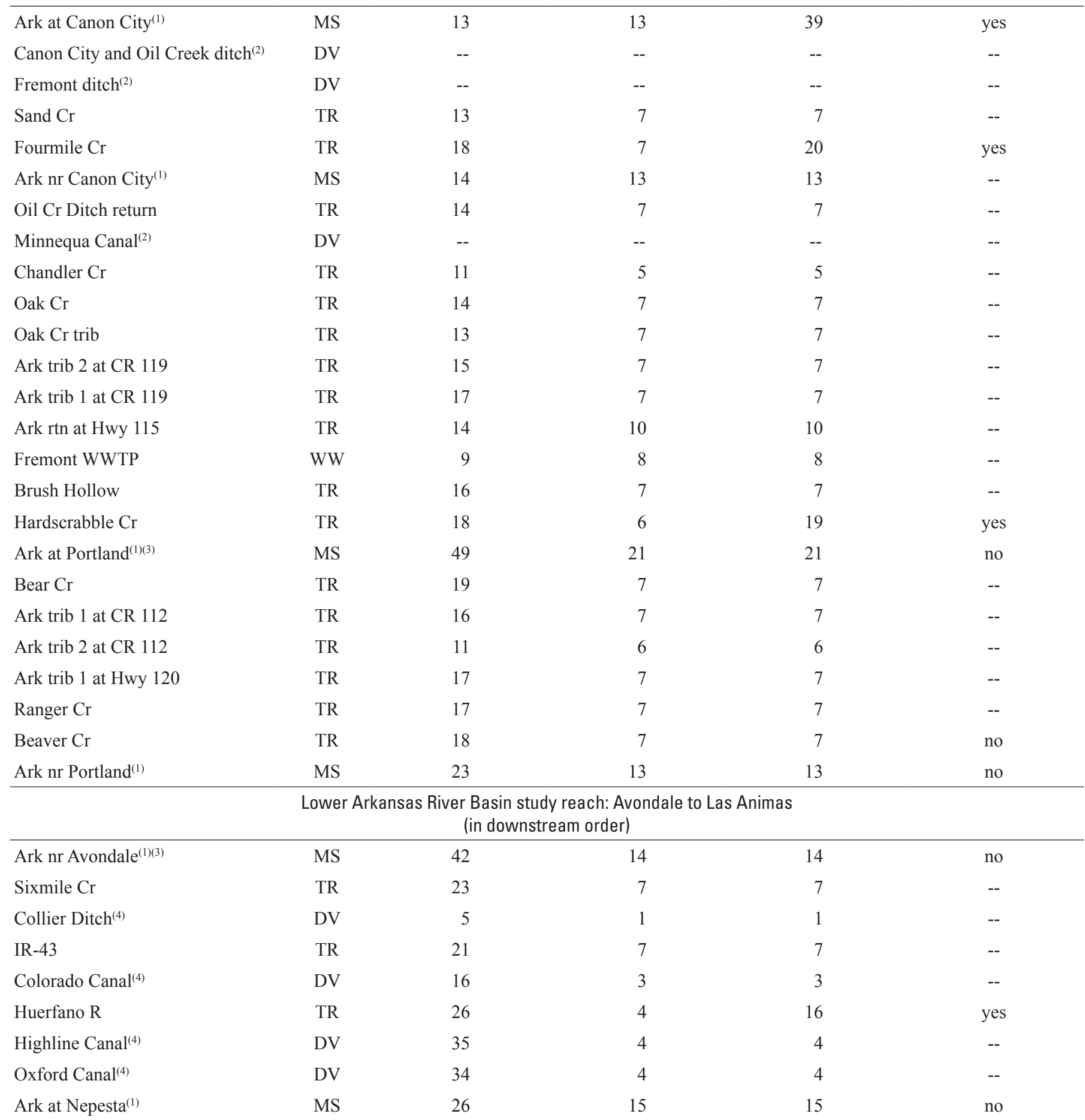


Table 2. Number of specific-conductance measurements and dissolved-solids samples collected at sites in the Upper Arkansas River Basin and Lower Arkansas River Basin study reaches in Colorado, 2009-2010.-Continued

[SC, specific conductance; DS, dissolved solids; MS, main stem; DV, diversion canal or ditch; TR, tributary; WW, wastewater treatment plant; --, no data available]

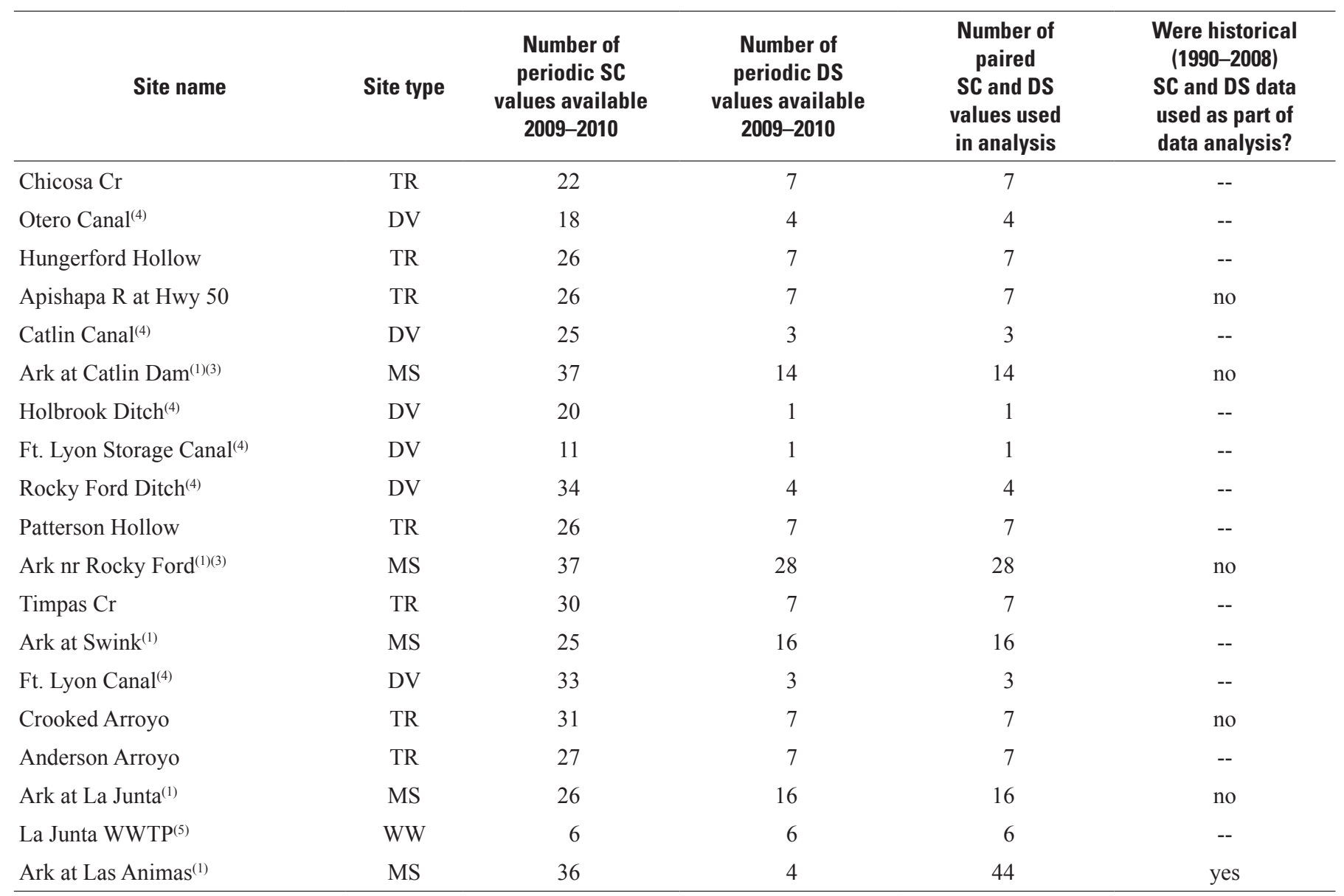

${ }^{1}$ Continuous water-quality monitor at this site.

${ }^{2}$ No dissolved-solids data collected; characteristics of nearest upstream main-stem site used in data analyses.

${ }^{3}$ Additional dissolved-solids data collected as part of other USGS water-quality sampling efforts included.

${ }^{4}$ Limited dissolved-solids data collected; characteristics of nearest upstream main-stem site used in data analyses.

${ }^{5}$ Samples only collected in 2009 at the La Junta wastewater treatment plant. 
Typically, daily streamflow data for established USGS gages are published in Annual Water Data Reports; streamflow data are published by water year (October 1 through September 30). Recent data (post-2005) can be accessed online at http://wdr.water.usgs.gov/index.html. Documentation describing the accuracy of the data and methodology used to collect and report these data also can be accessed at this web site. Seasonal streamflow data collected at numerous sites in the study reaches can be accessed through the USGS Automated Data Processing System (ADAPS) developed for the processing, storage, and retrieval of water data (U.S. Geological Survey, 2003). ADAPS is part of the NWIS developed by the USGS and is a distributed water database in which data can be processed over a network of computers at USGS offices throughout the United States.

The Colorado Division of Water Resources also publishes streamflow data for the Arkansas River Basin (Colorado Division of Water Resources, 2010). Hydrographic Program staff for the State of Colorado visit streamflow-gaging stations on a frequent basis to maintain equipment and ensure correct operation. They also perform discharge measurements for purposes of calibrating the stage-discharge relation for a gaging station, as well as take note of physical factors present at the station that may be affecting the stage-discharge relation.

Water-quality data collected as part of this report included continuous specific-conductance data collected at long-term or seasonally monitored sites and periodic water-quality data collected onsite. Daily SC data from established sites in the study area can be accessed through the NWIS web interface at http://waterdata.usgs.gov/nwis/ $q w$. Procedures for operation, computation, and reporting of continuous water-quality monitors are described in Wagner and others (2006). Continuous SC data collected at three seasonal sites in the study area can be accessed through ADAPS. Water-quality samples were collected on site and submitted to the USGS National Water Quality Laboratory in Lakewood, Colo., for chemical analysis. Quality-control and quality-assurance measures associated with these data are described by Ivahnenko and others (2012).

\section{Estimation of Gains and Losses in Streamflow from Unmeasured Sources and Sinks}

A common approach to investigating the flow of water from unmeasured sources or sinks is to measure streamflow at numerous points along a study reach to determine a water budget. These measurement points (sites) subdivide the stream into subreaches and account for inputs (such as tributaries and return flows) and outputs (such as diversions). The difference between inflows and outflows may be attributed to unmeasured sources or sinks, such as the interaction between the stream and the underlying aquifer. When applied to a defined reach, the quantity of flow attributable to unmeasured sources or sinks (the flux) can be estimated as

$$
\mathrm{Q}_{\text {flux }}=\mathrm{Q}_{\mathrm{ds}}-\mathrm{Q}_{\mathrm{us}}+\sum \mathrm{Q}_{\text {out }}-\sum \mathrm{Q}_{\mathrm{in}}
$$

where

$$
\begin{aligned}
& \mathrm{Q}_{\mathrm{ds}} \quad \begin{array}{l}
\text { is the streamflow at the downstream end of } \\
\text { the subreach, }
\end{array} \\
& \mathrm{Q}_{\mathrm{us}} \quad \begin{array}{c}
\text { is the streamflow at the upstream end of the } \\
\text { subreach, }
\end{array} \\
& \mathrm{Q}_{\text {out }} \quad \begin{array}{c}
\text { are outputs from the subreach such as } \\
\text { diversions, and }
\end{array} \\
& \mathrm{Q}_{\text {in }} \quad \begin{array}{c}
\text { are inputs to the reach such as tributaries or } \\
\text { sewage outfalls. }
\end{array}
\end{aligned}
$$

As such, a positive $Q_{\text {flux }}$ indicates a net gain of water to the subreach in the form of groundwater or unmeasured surface-water inflow. A negative $\mathrm{Q}_{\text {flux }}$ indicates a net loss of surface water to the groundwater system, evapotranspiration, unmeasured diversions, or other sinks. This loss is commonly termed a transmission loss.

The quantification of all fluxes to or from the river is a simple concept, but can be difficult to apply. The method requires an accurate measurement of streamflow as well as a complete accounting of all other gains and losses evident for the reach. The uncertainties associated with the streamflow measurements and estimates for water-balance components such as unmetered extraction, evapotranspiration, ungaged tributary flows, overbank flooding losses, and flood return flows can exceed the magnitude of the seepage flux being estimated (Commonwealth of Australia, 2006). Streamflow measurement errors can be +25 percent during high-flow conditions, and from -50 to +100 percent for flash floods in semiarid catchments (Lerner and others, 1990).

A water budget provides a reasonable accounting of the water in the system if all identified inflow and outflows have been quantified. However, inherent uncertainties are associated with the collection of the data needed to calculate a water budget for the Arkansas River. Typically, streamflow measurements performed by the USGS and the State of Colorado can be assumed to have an error of less than 10 percent (Rantz and others, 1982a). Given the other unmeasured components of error in this analysis, error bars of \pm 15 percent of the averaged daily streamflow of the upstream and downstream main-stem sites within a subreach were calculated to help evaluate the results. A value of \pm 15 percent was determined to be sufficiently conservative to allow for the identification of stream reaches where streamflow gains or losses exceeded the measurement error. Consistent exceedences of the error bars could potentially indicate stream reaches where surface-water inflows or groundwater inputs from unmeasured sources and sinks are a substantial part of the water budget. 


\section{Gains and Losses in Streamflow in the Upper Arkansas River Basin Study Reach}

The UARB study reach contains two long-term streamflow gages (fig. 2); both sites are managed by the State of Colorado. Comparisons of total annual streamflow for the upstream site, Ark at Canon City, and the downstream site, Ark at Portland, indicated that this generally was a gaining reach. In 2009 and 2010, total annual streamflow increased 3.7 percent and 4.0 percent, respectively, in the downstream direction.

Comparisons of monthly streamflow totals, however, indicated substantial variations in the percentage change in streamflow on a seasonal basis (fig. 5). Overall, changes in total monthly streamflow in 2009 and 2010 for the reach ranged from -4.7 percent (indicating a losing reach) to 36.2 percent (indicating a gaining reach). Typically, a loss of water occurred during the winter months (December-March) when base-flow conditions were prevalent. During this period, as much as 60 percent of the streamflow observed at the upstream gaged site (Ark at Canon City) was diverted into the Minnequa Canal. During the snowmelt runoff period (April-August), streamflow increased in the downstream direction as tributary and groundwater inputs exceeded the amount of water diverted from the river. Generally, diversion totals accounted for less than 10 percent of the streamflow in the river at these higher streamflow conditions. Overall, the increase in total monthly streamflow from Ark at Canon City to Ark at Portland during the snowmelt runoff period was between 1.5 and 12.2 percent. From September through November, groundwater return flows became more pronounced as streamflow in the river decreased. The increase in streamflow along the reach during this period ranged from 10.6 to 36.2 percent even as diversions continued to remove water from the river.

Data collected as part of this study were intended to fill data gaps associated with an analysis of water budgets along subreaches of the Arkansas River. In the UARB, the collection of additional streamflow data at previously ungaged tributary sites and two main-stem sites provided additional data needed to improve the estimates of streamflow from unmeasured sources during the study period. The results of these analyses for the subreaches are described in the following sections of this report. Statistical smoothing of the gains and losses from unmeasured streamflow using LOWESS techniques were used to help interpret the results of the overall water budget. Error bars of \pm 15 percent were used to indicate the potential error associated with the streamflow estimations. As such, it was assumed that inputs to the river from unmeasured sources of surface water or groundwater were evident when the LOWESS line consistently exceeded the upper 15-percent error bar. Conversely, a loss of water within a subreach (a sink) was evident when the LOWESS line consistently exceeded the lower 15-percent error bar. Subreaches of the UARB between main-stem gages are discussed to examine if gains or losses from unmeasured sources or sinks, such as ungaged surface flows or surface-water groundwater interactions, occurred along any particular subreach.

\section{Canon City to Portland}

Estimates of gains or losses from unmeasured streamflow along the 5-mile river subreach from Ark at Canon City downstream to Ark nr Canon City during 2009 and 2010 are shown in figure 6. Estimates were only made for periods when all the seasonal streamflow gages in this subreach were operational. Daily streamflow data from two tributary inputs and two diversion structures were used to estimate the daily water budget along this reach (table 1). In 2009, estimates of unmeasured streamflow exceeded the 15-percent error bar (an unmeasured gain) during August through October (fig. 6A). Similar results were observed the following year from August into November, when data collection was discontinued (fig. 6B). These results generally were consistent with the description of total monthly streamflow described previously in this report. The magnitude of the unmeasured streamflow flux to the Arkansas River along this subreach was relatively consistent between the 2 years and was estimated to be about 100 cubic feet per second $\left(\mathrm{ft}^{3} / \mathrm{s}\right)$ or $20 \mathrm{ft}^{3} / \mathrm{s}$ per river mile. The river mileage of this subreach of the Arkansas River is approximately one-third of the total river mileage between the Ark at Canon City and Ark at Portland gages.

Estimates of gains and losses from unmeasured streamflow along the 11-mile river subreach from Ark nr Canon City downstream to Ark at Portland during 2009-2010 are shown in figure 7. Estimates were only made for periods when all the seasonal streamflow gages in this subreach were operational. Daily streamflow data from nine tributary or ditch-return inputs, one wastewater input, and one diversion structure were used to estimate the daily water budget along this reach (table 1). Estimates of the daily water budget during the late summer and fall of 2009 indicated that the unmeasured streamflow flux to the river was within the potential error of measurement ( \pm 15 percent), as defined earlier in this report (fig. $7 A$ ). Similar results were observed for daily estimates in 2010 including the high-flow period from late May through July (fig. $7 B$ ). As such, there is no indication that gains or losses from unmeasured streamflow could be quantified in this subreach of the Arkansas River.

\section{Portland to Pueblo Reservoir}

Estimates of gains and losses from unmeasured streamflow along the 7-mile subreach from Ark at Portland downstream to Ark nr Portland during 2009-2010 are shown in figure 8. Estimates were only made for periods when all the seasonal streamflow gages in this reach were operational. Daily streamflow data from six tributary inputs were used to estimate the daily water budget along this subreach (table 1). During 2009, estimates of the daily water budget along this subreach of the river indicated that the unmeasured streamflow flux to the river was within the potential error of measurement, as defined for this analysis (fig. 8A). Similar results were observed for daily estimates in 2010 (fig. $8 B$ ) including the high-flow period from late May through July. As such, there is no indication that gains or losses from unmeasured streamflow could be quantified in this subreach of the Arkansas River. 

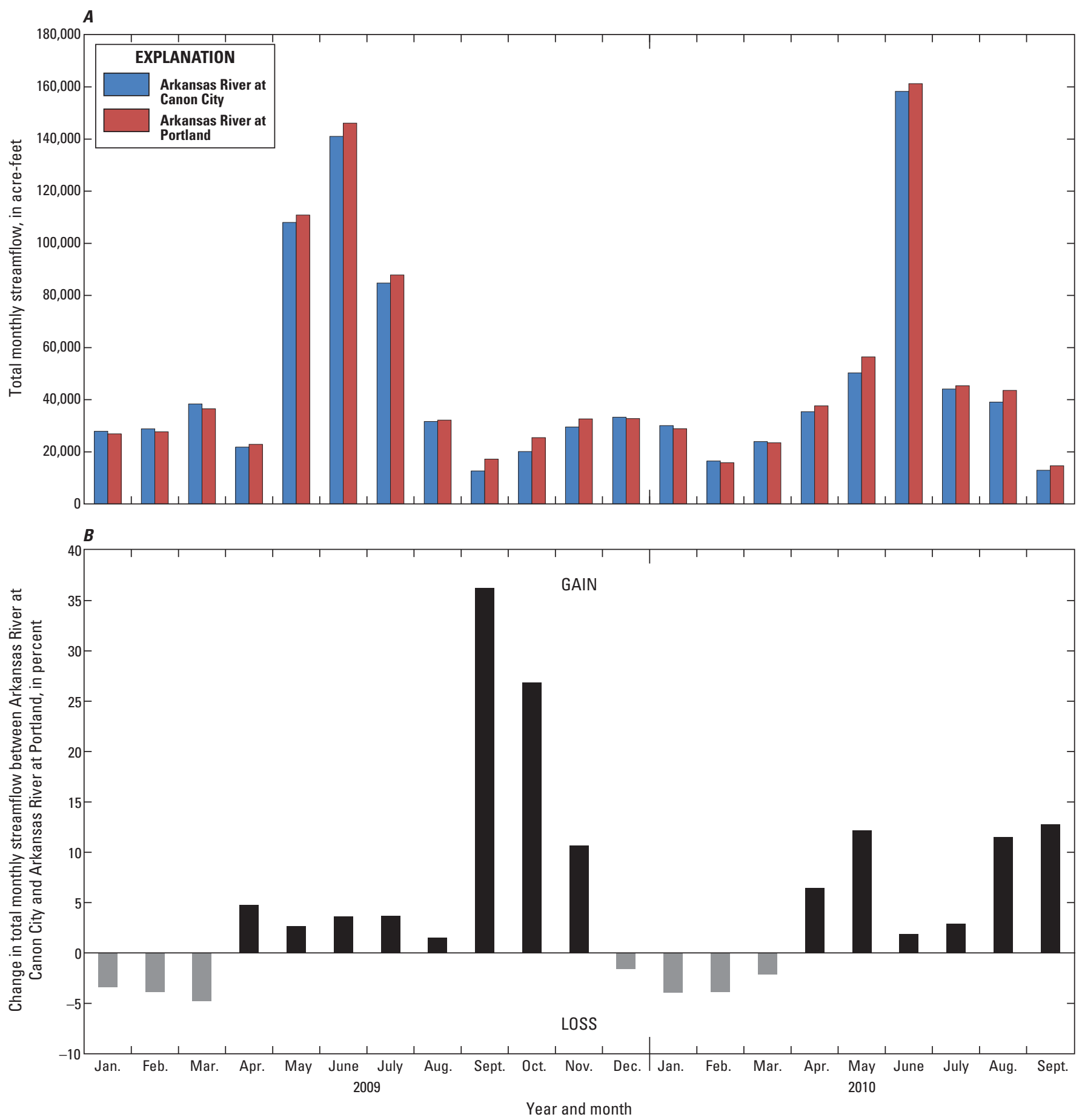

Figure 5. (A) Total monthly streamflow and $(B)$ percentage change in total monthly streamflow between Arkansas River at Canon City to Arkansas River at Portland, Colorado, 2009-2010. 

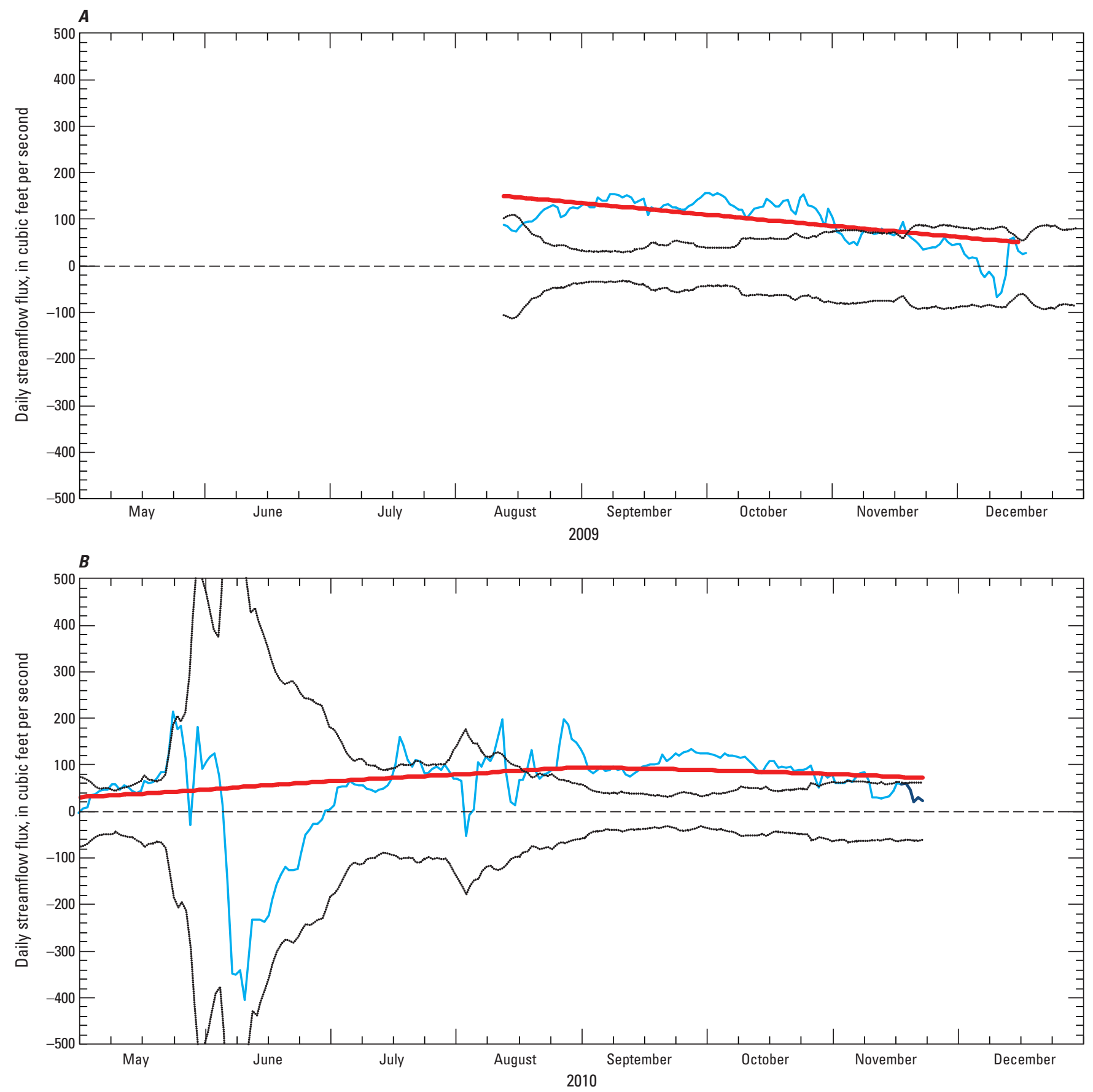

EXPLANATION

Unmeasured streamflow flux

15-percent error bar-The averaged estimated daily streamflow of the upstream and downstream main-stem sites in the subreach

LOWESS smoothing curve

Figure 6. Estimated daily gains and losses from unmeasured streamflow along a subreach of the Upper Arkansas River Basin from Arkansas River at Canon City downstream to Arkansas River near Canon City, Colorado, $(A) 2009$ and $(B) 2010$. 

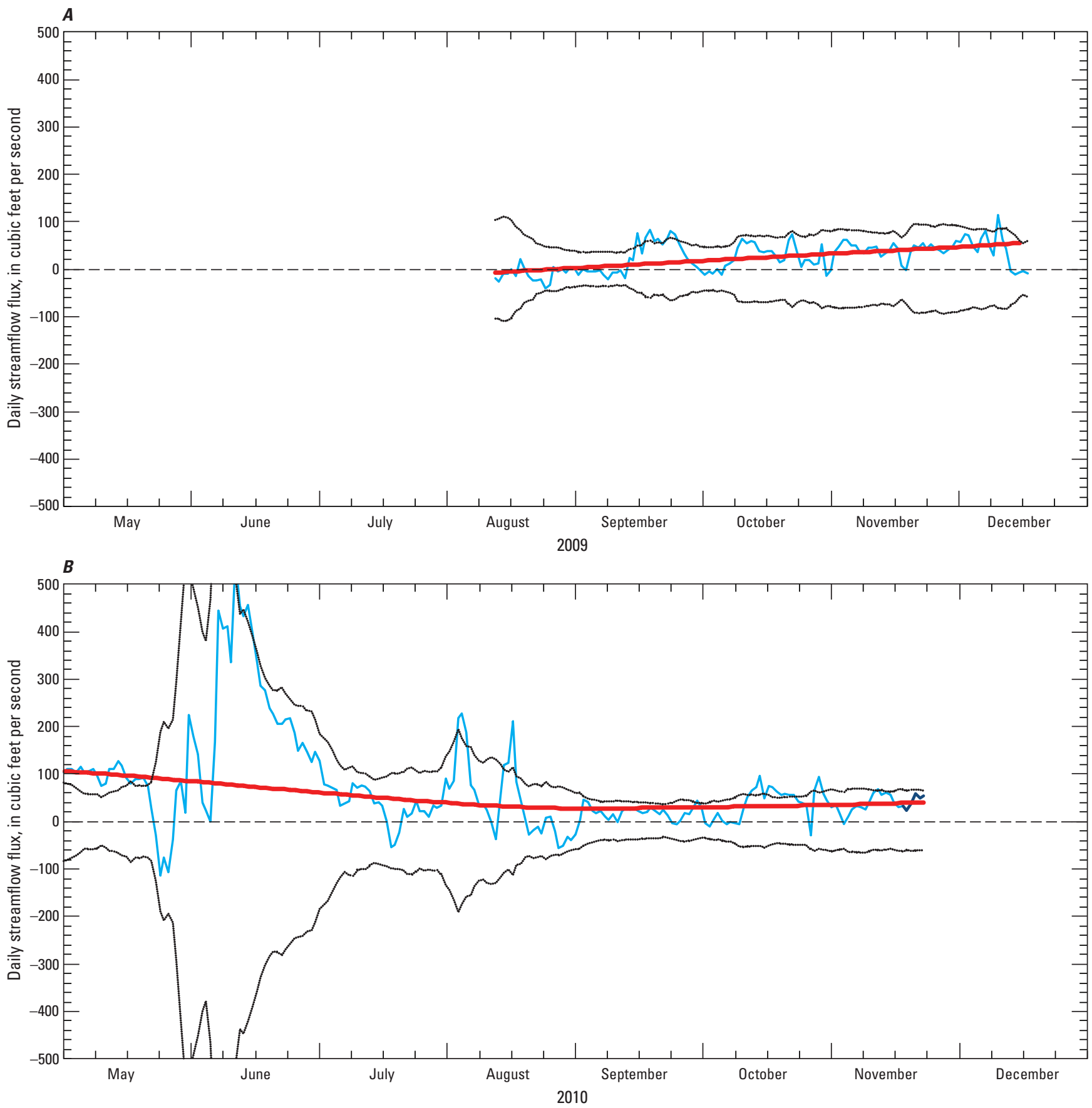

EXPLANATION

Unmeasured streamflow flux

15-percent error bar-The averaged estimated daily streamflow of the upstream and downstream main-stem sites in the subreach

LOWESS smoothing curve

Figure 7. Estimated daily gains and losses from unmeasured streamflow along a subreach of the Upper Arkansas River Basin from Arkansas River near Canon City downstream to Arkansas River at Portland, Colorado, $(A) 2009$ and $(B) 2010$. 

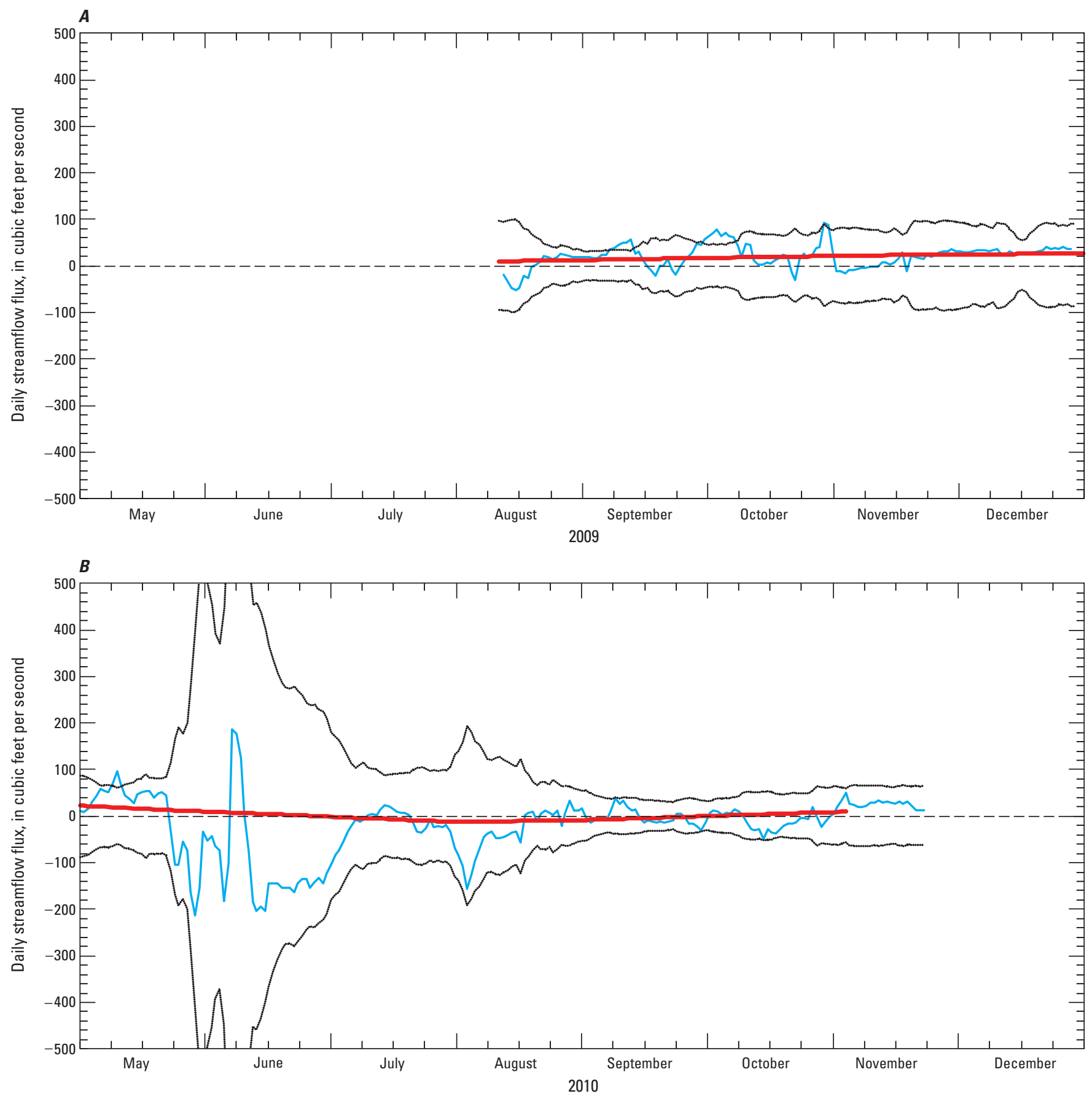

EXPLANATION

Unmeasured streamflow flux

15-percent error bar-The averaged estimated

daily streamflow of the upstream and downstream

main-stem sites in the subreach

LOWESS smoothing curve

Figure 8. Estimated daily gains and losses from unmeasured streamflow along a subreach of the Upper Arkansas River Basin from Arkansas River at Portland downstream to Arkansas River near Portland, Colorado, $(A) 2009$ and $(B) 2010$. 


\section{Gains and Losses in Streamflow in the Lower Arkansas River Basin Study Reach}

The LARB study reach contains several long-term streamflow gaging sites (table 1); the sites are operated and maintained either by the USGS or by the State of Colorado. Historical analyses of the total annual streamflow at streamflow gages in the LARB typically have focused on three main-stem sites (Ark nr Avondale, Ark at Catlin Dam, and Ark at Las Animas) where long-term streamflow data are coupled with continuous SC data collection (fig. 3). Miller and others (2010) compared average annual streamflow at these three sites and reported that a substantial decrease in streamflow was observed in the downstream direction for their analysis period of 2000-2006. The Arkansas River in the LARB study reach has been shown to exhibit decreased streamflow in the downstream direction by other investigators including Ortiz and others (1998), Lewis and Brendle (1998), and Cain (1985).

Comparisons of total annual streamflow (2009-2010) for the two upstream gages, Ark nr Avondale and Ark at Catlin Dam, indicated that substantial amounts of water were removed along this subreach of the river. Total annual streamflow decreased by 44 percent (2009) and 41 percent (2010) between the two gaging sites. Several large diversion ditches including the Rocky Ford Highline and the Colorado Canal are located between these two main-stem gages. Similarly, comparisons of total annual streamflow between Ark at Catlin Dam and Ark at Las Animas exhibited decreased flow in the downstream direction. In 2009 and 2010, streamflow decreased 54 percent and 58 percent, respectively, between the two gaging sites. Several large diversion ditches including the Catlin Canal and the Fort Lyon Canal remove water along this subreach.

Comparisons of total monthly streamflow from Ark nr Avondale to Ark at Catlin Dam indicated that streamflow generally decreased in this subreach (fig. 9). Decreases in total monthly streamflow from Avondale to Catlin Dam ranged from 15 percent to nearly 80 percent for most of the year. Some gains in streamflow occurred in the late fall just after the cessation of the irrigation season in the LARB. One intermediate main-stem site, Ark at Nepesta, is located along this subreach and is operated by the State of Colorado. Comparisons of total monthly streamflow along the subreaches from Avondale to Nepesta and from Nepesta to Catlin Dam generally were similar to the overall profile shown in figure 9 for the reach from Avondale to Catlin Dam.

Overall, comparisons of total monthly streamflow from Ark at Catlin Dam to Ark at Las Animas indicated decreased streamflow in this subreach (fig. 10). Decreases in total monthly streamflow during 2009-2010 ranged from about 8 percent to about 80 percent. A gain in streamflow was observed during a low-flow period in February 2009 when the total monthly streamflow increased downstream by 2,224 acre-ft, resulting in a 49-percent increase in streamflow.

Although streamflow generally decreased in 2009 and 2010 in the subreach from Ark at Catlin Dam to Ark at Las Animas, monthly streamflow comparisons at a smaller subreach level showed different seasonal patterns. The State of Colorado operates two intermediate long-term main-stem sites (Ark nr Rocky Ford and Ark at La Junta) within this reach (fig. 3). A third site, Ark at Swink, was located between Rocky Ford and La Junta. This site was operated seasonally by the USGS but limited data were available for monthly streamflow analysis.

Decreases in streamflow were prevalent during most months between Ark at Catlin Dam and Ark nr Rocky Ford, but there was a marked difference in the magnitude of the losses seasonally (fig. 11). In contrast to the losses in streamflow in the subreach upstream from Catlin Dam, streamflow losses along this subreach occurred during the late fall and winter after most irrigation companies had stopped diverting water. Water is diverted during this time, however, into the Fort Lyon Storage Canal for storage in two off-channel reservoirs. The Fort Lyon Storage Canal diverted nearly 60,000 acre-ft of water in 2009 with the vast majority of the diversions occurring from mid-November to April (Colorado Decision Support System, 2011).

Between Ark nr Rocky Ford and Ark at La Junta, losses were prevalent during most months when irrigation diversions were operating in the LARB (fig. 12). Of particular importance in this subreach is the Fort Lyon Canal. In 2010, nearly 190,000 acre-ft of water were diverted through the Fort Lyon Canal (Colorado Decision Support System, 2011). Located just west of La Junta, the Fort Lyon Canal is the largest diversion in the study area. Similar to other reaches of the river, streamflow increased downstream during the winter after the irrigation season had ended. It is important to note the magnitude of the streamflow gains during the nonirrigation season (low flows) and losses during the irrigation season (high flows) when evaluating the percentage changes on a seasonal basis (fig. 12A). A 56-percent gain in February 2009 resulted in an additional 1,500 acre-ft of water in the river, while a 56-percent loss in May 2010 resulted in the removal about 28,000 acre- $\mathrm{ft}$ of water from the river.

From Ark at La Junta downstream to Ark at Las Animas, losses were prevalent during the irrigation season but the decrease in total monthly streamflow generally was less than 20 percent (fig. 13). Similar to most other subreaches in the LARB, increased monthly streamflow in the river was observed during the winter after the irrigation season had ended. Increases of only a few percent to near 100 percent were observed in this subreach. It is important to note that streamflow in the Arkansas River is at its lowest at La Junta during the winter (fig. 13A), and relatively small increases in downstream flows can result in a relatively large increase in the overall percentage increase calculated for this analysis. 

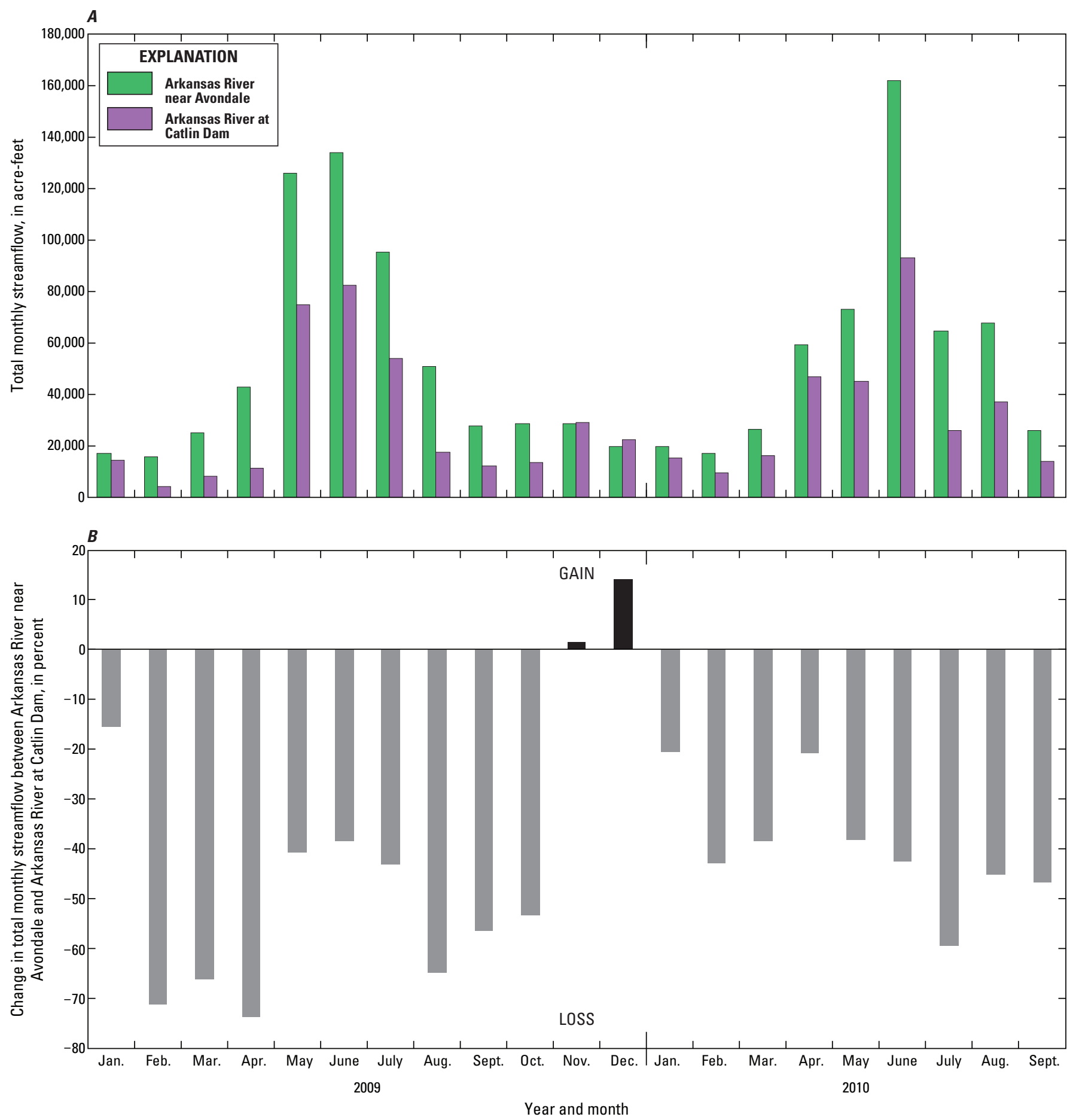

Figure 9. (A) Total monthly streamflow and $(B)$ percentage change in total monthly streamflow from Arkansas River near Avondale to Arkansas River at Catlin Dam, Colorado, 2009-2010. 

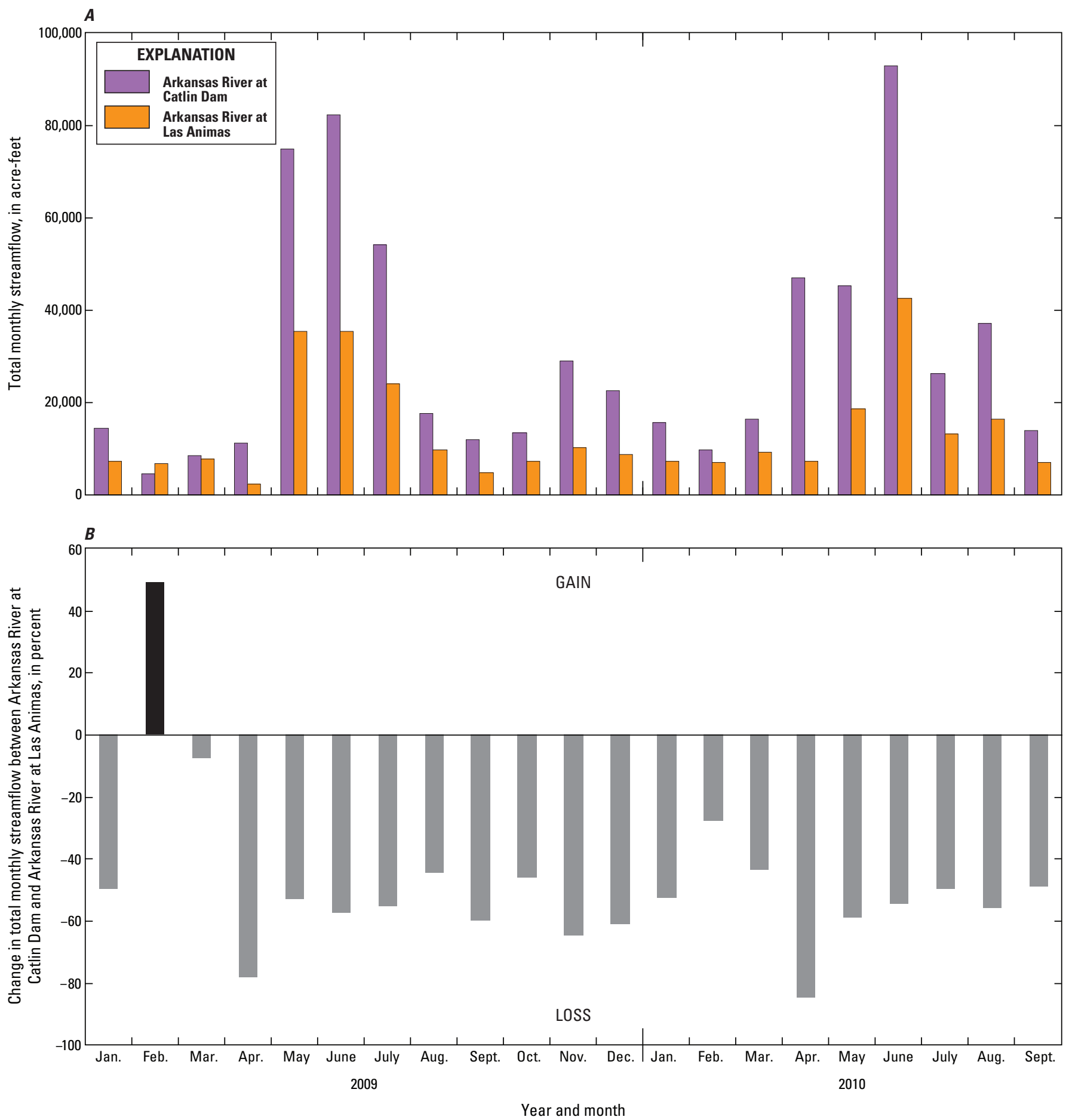

Figure 10. (A) Total monthly streamflow and $(B)$ percentage change in total monthly streamflow from Arkansas River at Catlin Dam to Arkansas River at Las Animas, Colorado, 2009-2010. 

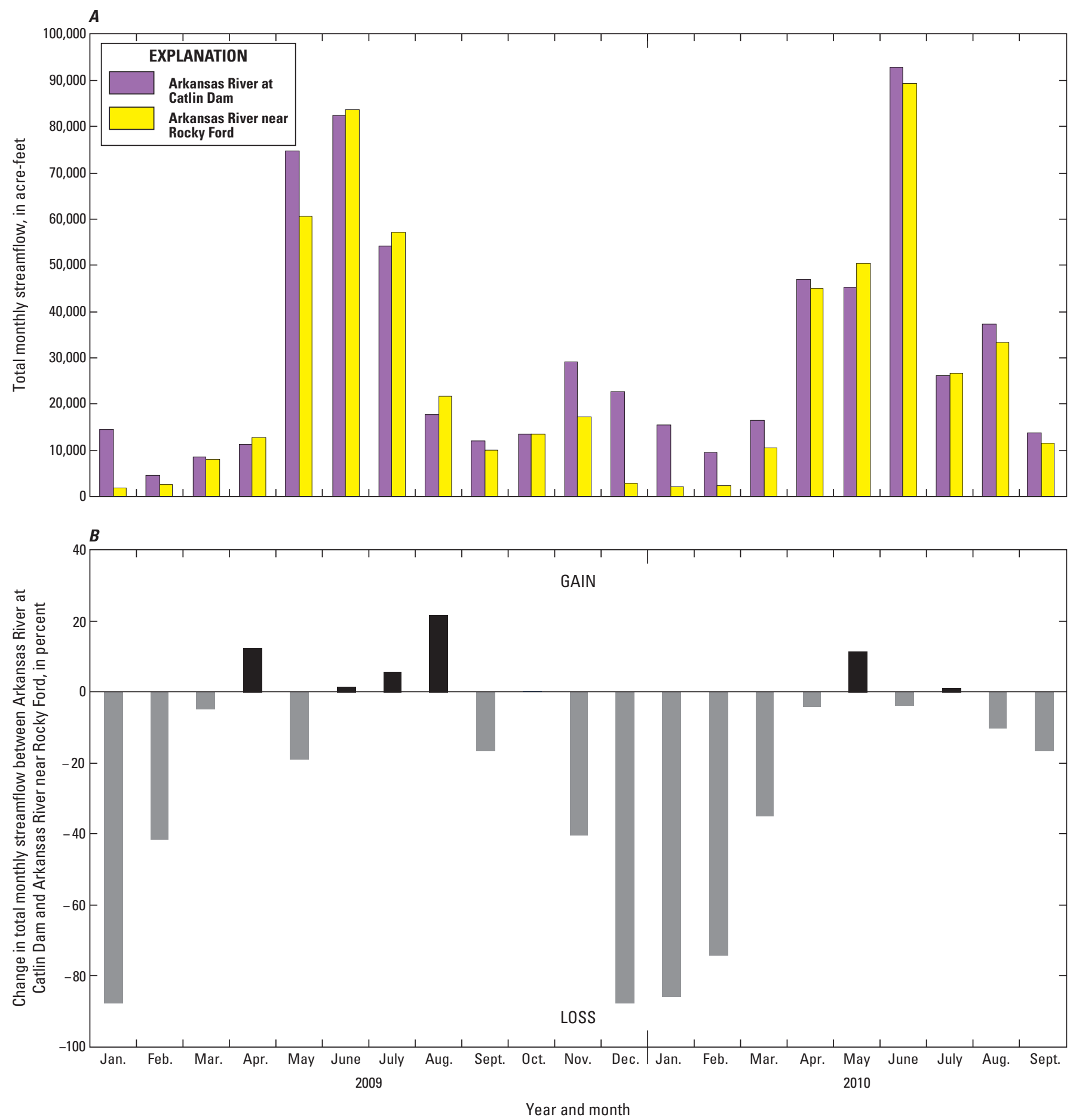

Figure 11. (A) Total monthly streamflow and $(B)$ percentage change in total monthly streamflow from Arkansas River at Catlin Dam to Arkansas River near Rocky Ford, Colorado, 2009-2010. 

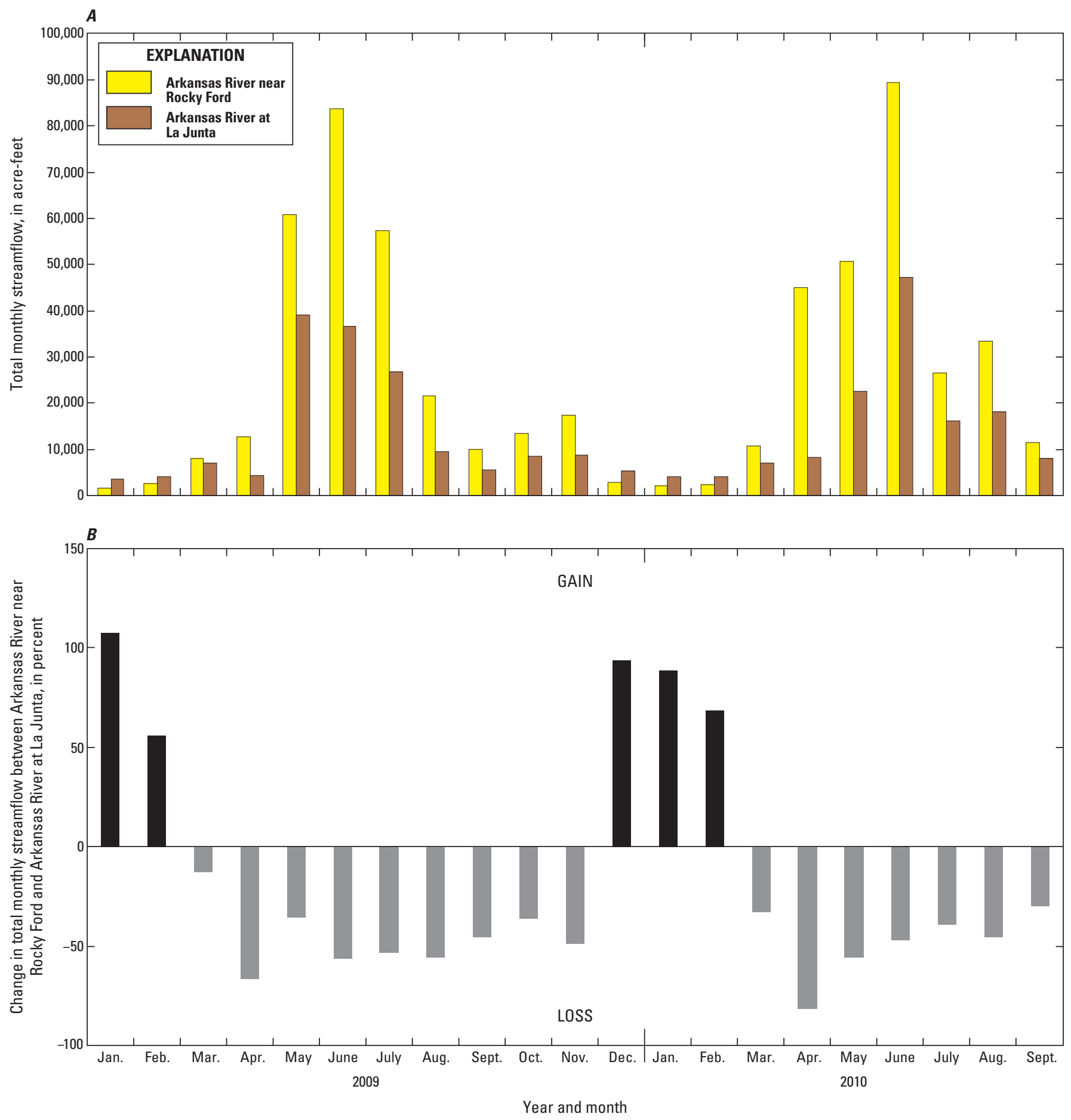

Figure 12. (A) Total monthly streamflow and $(B)$ percentage change in total monthly streamflow from Arkansas River near Rocky Ford to Arkansas River at La Junta, Colorado, 2009-2010. 

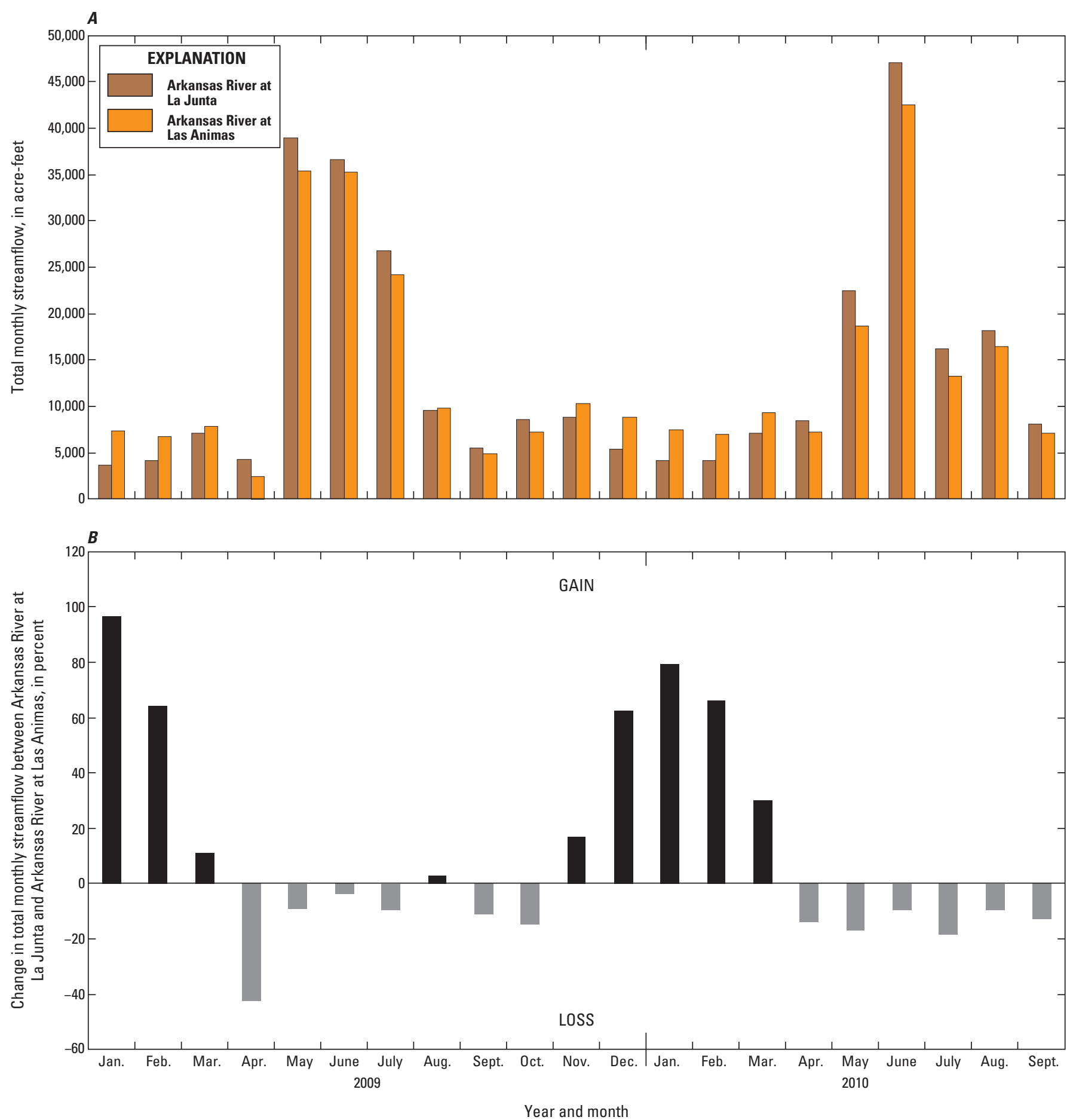

Figure 13. (A) Total monthly streamflow and $(B)$ percentage change in total monthly streamflow from Arkansas River at La Junta to Arkansas River at Las Animas, Colorado, 2009-2010. 


\section{Avondale to Catlin Dam}

Estimates of gains and losses from unmeasured streamflow along the 21-mile subreach from Ark nr Avondale downstream to Ark at Nepesta during 2009-2010 are shown in figure 14. Estimates were only made for periods when all the seasonal streamflow gages in this subreach were operational; long-term annual data were available for the main-stem sites, but data for many of the tributaries were seasonal. Daily streamflow data from three tributary inputs and four diversion structures were used to estimate the daily water budget along this subreach (table 1). In 2009, estimates of gains or losses from unmeasured streamflow did not exceed the \pm 15 -percent error bars, as illustrated by the LOWESS line in figure $14 A$. Recall that LOWESS estimates greater than the error bars were considered an indicator of unmeasured sources or sinks to the Arkansas River that were not accounted for in the water budget. Similar results were observed the following year in 2010 (fig. 14B).

Estimates of gains and losses from unmeasured streamflow for the 15-mile subreach from Ark at Nepesta downstream to Ark at Catlin Dam during 2009-2010 are shown in figure 15. Estimates were only made for periods when all the seasonal streamflow gages in this subreach were operational; long-term annual data were available for the main-stem sites, but data for many of the tributaries were seasonal. Daily streamflow data from three tributary inputs and two diversion structures were used to estimate the daily water budget along this subreach (table 1). In 2009, estimates of unmeasured streamflow exceeded the lower 15-percent error bar (unmeasured losses) for a brief time in September; otherwise, the estimates remained within the stated error bars until data collection ended in late December (fig. 15A). In 2010, estimated losses from unmeasured streamflow occurred for an extended period from September through November (fig. 15B). Estimated losses from unmeasured streamflow occurred at a rate of about $6 \mathrm{ft}^{3} / \mathrm{s}$ per river mile. The mechanism and spatial extent of the losses in this subreach of the Arkansas River were not identified, and further investigation would be required to better quantify the estimated losses.

\section{Catlin Dam to Las Animas}

Estimates of daily gains and losses from unmeasured streamflow for the 20-mile subreach from Ark at Catlin Dam downstream to Ark nr Rocky Ford during 2009-2010 are shown in figure 16. Estimates were only made for periods when seasonal streamflow gages in this subreach were operational. Long-term annual data were available for the main-stem sites, but data for the one tributary site were seasonal. Daily streamflow data from one tributary, one reservoir outlet site (Lake Meredith), and three diversion structures were used to estimate the daily water budget along this subreach (table 1). In 2009, estimates of unmeasured streamflow exceeded the 15-percent error bar (unmeasured gain) from early September through mid-October and from mid-November through December, when data collection ceased (fig. 16A). In 2009, there appeared to be a consistent positive shift to the LOWESS line, which suggested that gains from unmeasured flow sources were evident along the subreach. The estimated gain occurred at a rate of less than $2 \mathrm{ft}^{3} / \mathrm{s}$ per river mile. In 2010, there appeared to be no consistent exceedence of the 15-percent error bar (fig. 16B).

Estimates of daily gains and losses from unmeasured streamflow for the 13-mile subreach from Ark nr Rocky Ford downstream to Ark at La Junta during 2009-2010 are shown in figure 17. Estimates were only made for periods when all the seasonal streamflow gages in this subreach were operational; long-term annual data were available for the main-stem sites, but data for the tributary sites were seasonal. Daily streamflow data from three tributary inputs and one diversion structure were used to estimate the daily water budget along this subreach (table 1). In 2009, estimates of unmeasured streamflow exceeded the 15-percent error bar (unmeasured gains) from September through mid-October and from mid-November to mid-December (fig. 17A). Similar results were observed the following year in 2010 (fig. 17B). Overall, there appeared to be a consistent positive shift to the LOWESS line from September through December for both years, which suggested that gains from unmeasured flow sources were evident along the subreach. The estimated gains from unmeasured sources were about $26 \mathrm{ft}^{3} / \mathrm{s}$, which equated to a rate of about $2 \mathrm{ft}^{3} / \mathrm{s}$ per river mile.

Estimated daily gains and losses from unmeasured streamflow along the subreach from Rocky Ford to La Junta utilized two long-term streamflow gages operated by the State of Colorado (fig. 17). However, an intermediate streamflow gage at Swink was operated seasonally by the USGS during the study period. As such, data were available to calculate daily water budgets for two subreaches between Rocky Ford and La Junta. Estimations of daily gains and losses from unmeasured streamflow along the short subreach from Rocky Ford to Swink (fig. 18) and from Swink to La Junta (fig. 19) are discussed here.

Daily streamflow data from one tributary input was used to estimate the daily water budget along the 6.3-mile subreach from Ark nr Rocky Ford to Ark at Swink (table 1). In 2009, estimates of gains and losses from unmeasured streamflow exceeded the 15-percent error bar (unmeasured gains) in September and October; the LOWESS line mostly exceeded the 15-percent error bar during this period (fig. 18A). In 2010, the LOWESS line only exceeded the error bars in October and November (fig. 18B). The estimated gains from unmeasured sources were about $20 \mathrm{ft}^{3} / \mathrm{s}$, which equated to a rate of about $3 \mathrm{ft}^{3} / \mathrm{s}$ per river mile.

Daily streamflow data from two tributary inputs and one diversion structure were used to estimate the daily water budget along the 6.8-mile subreach from Ark at Swink to Ark at La Junta (table 1). In 2009, estimates of gains or losses from unmeasured streamflow did not exceed the \pm 15 -percent error bar, and there appeared to be little if any shift to the LOWESS line from the zero line during this time (fig. 19A). In 2010 , estimates of unmeasured streamflow only exceeded the 15-percent error bar (unmeasured gain) in late August through September and for a short time in October. Overall, there appeared to be no consistent positive shift to the LOWESS line in the later months of the analysis (fig. 19B). 

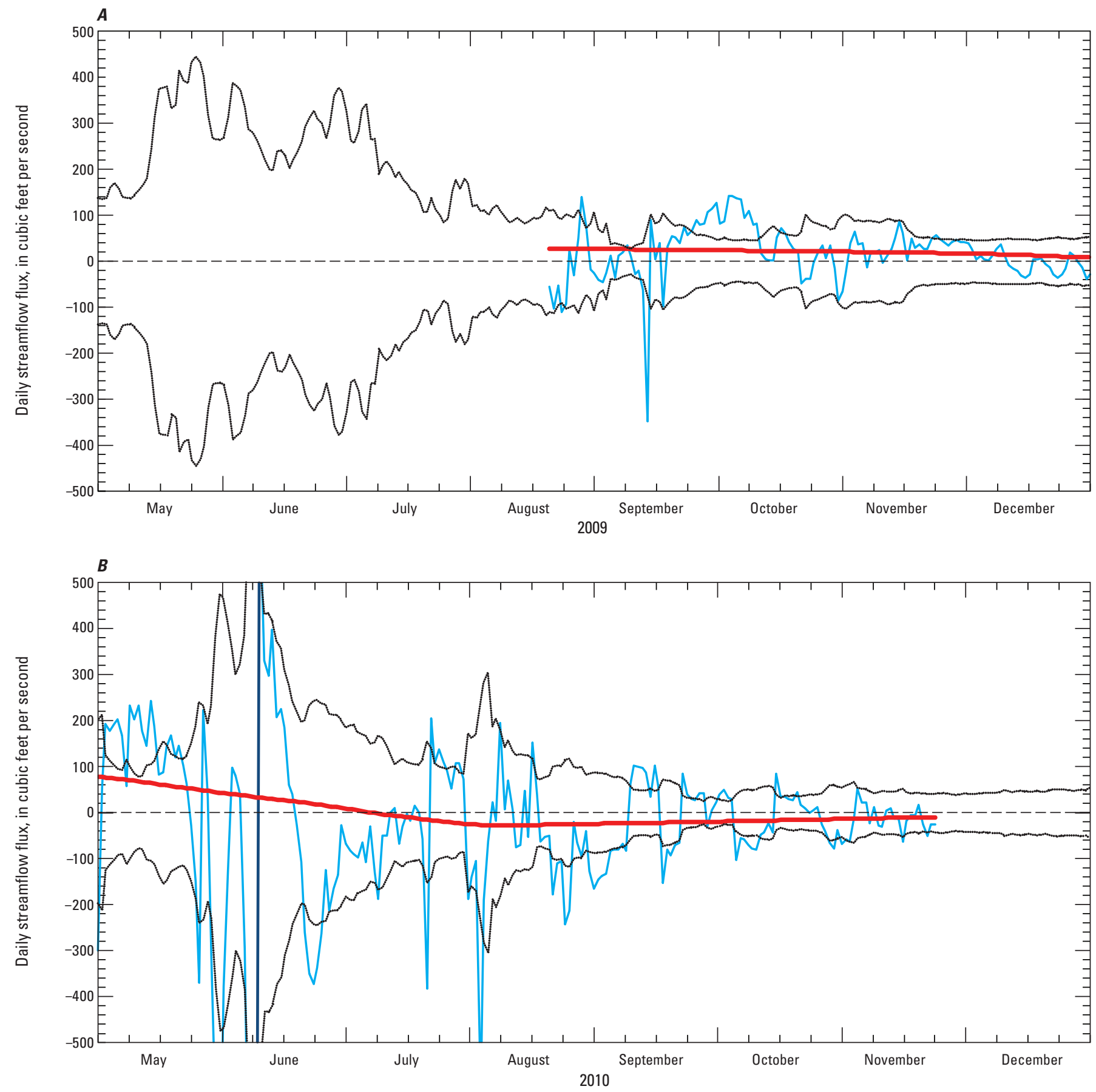

EXPLANATION

- Unmeasured streamflow flux

15-percent error bar-The averaged estimated daily streamflow of the upstream and downstream main-stem sites in the subreach

LOWESS smoothing curve

Figure 14. Estimated daily gains and losses from unmeasured streamflow along a subreach of the Lower Arkansas River Basin from Arkansas River near Avondale downstream to Arkansas River at Nepesta, Colorado, (A) 2009 and (B) 2010. 

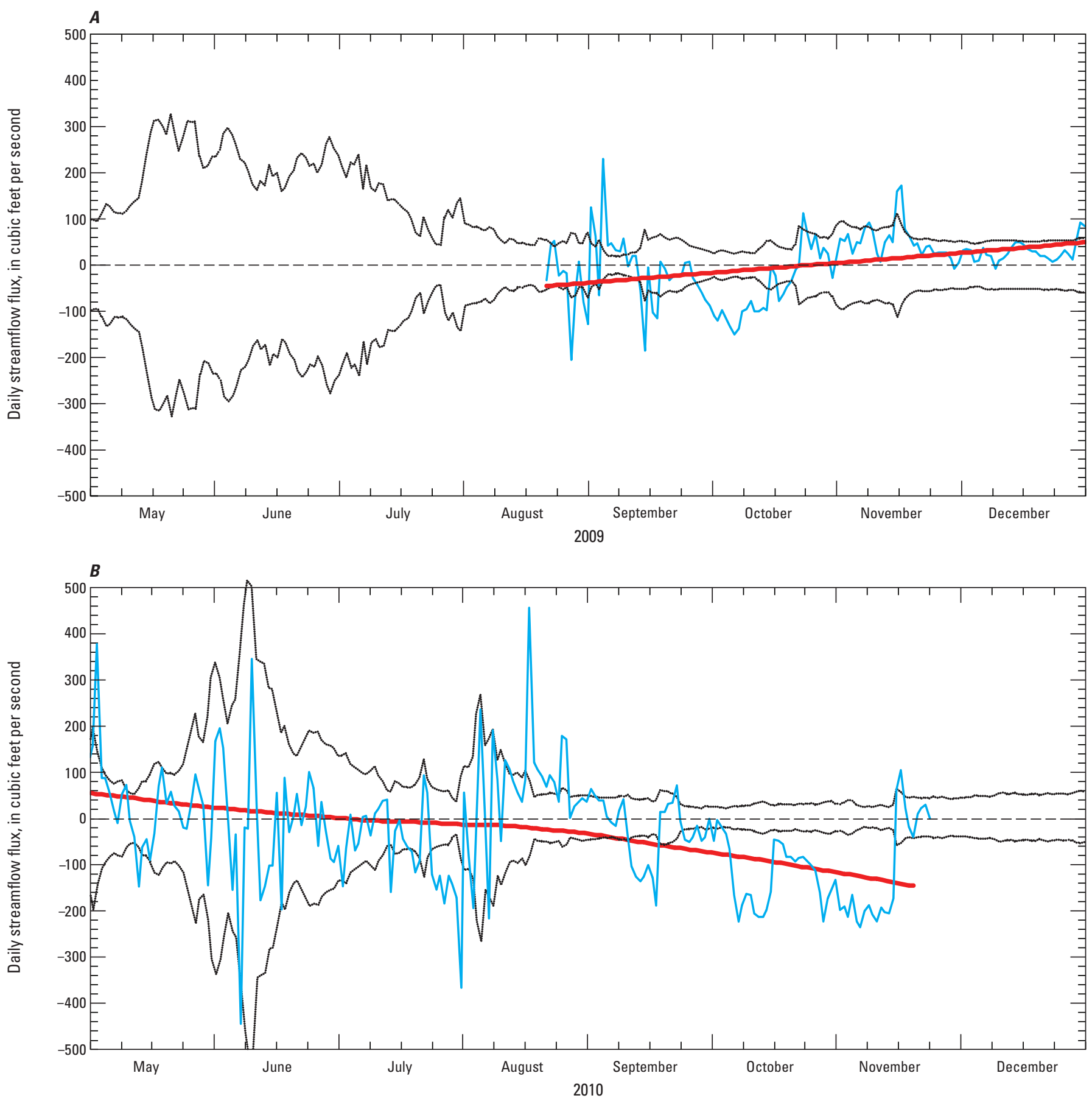

EXPLANATION

— Unmeasured streamflow flux

15-percent error bar-The averaged estimated daily streamflow of the upstream and downstream main-stem sites in the subreach

LOWESS smoothing curve

Figure 15. Estimated daily gains and losses from unmeasured streamflow along a subreach of the Lower Arkansas River Basin from Arkansas River at Nepesta downstream to Arkansas River at Catlin Dam, Colorado, (A) 2009 and $(B) 2010$. 

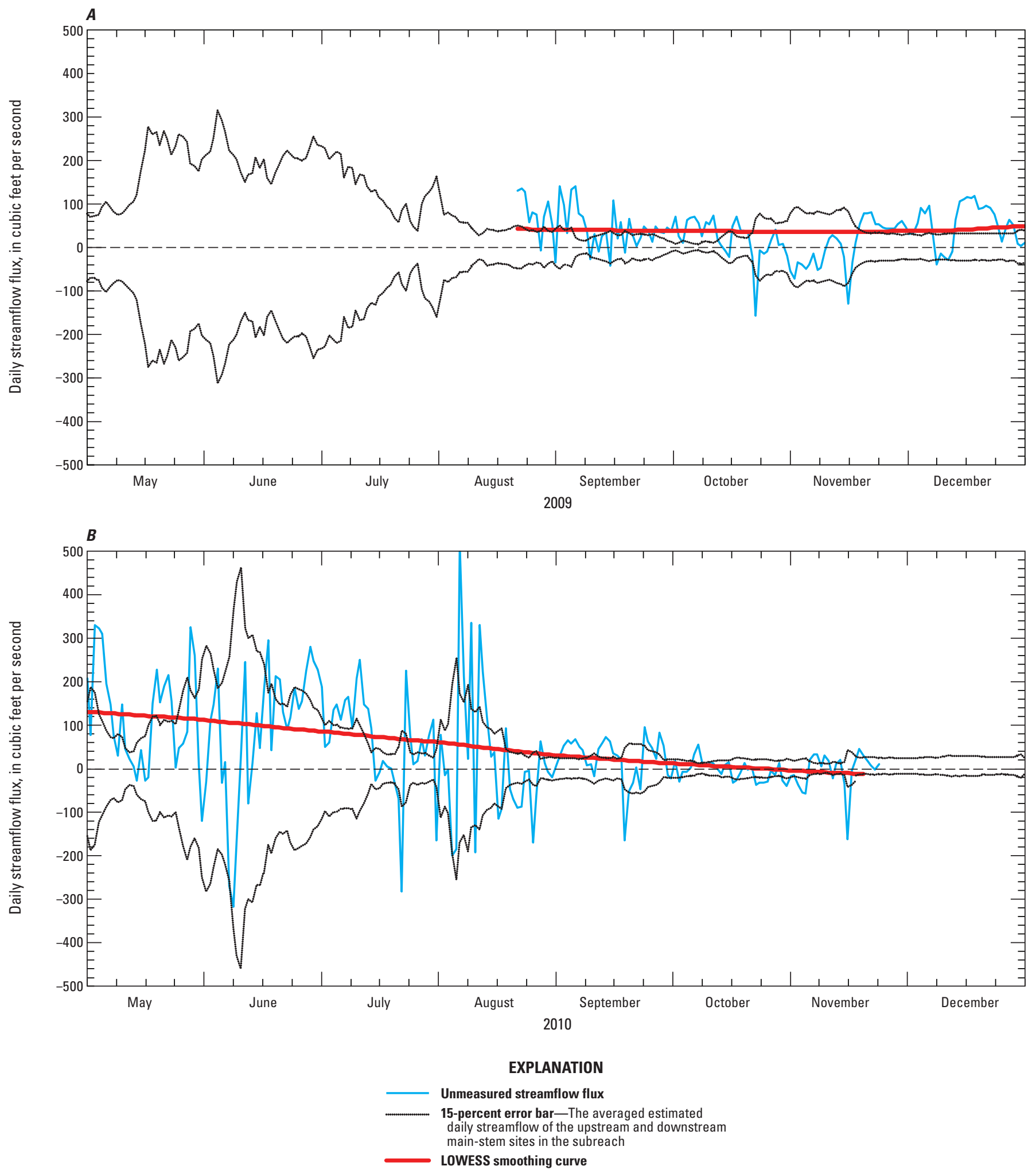

Figure 16. Estimated daily gains and losses from unmeasured streamflow along a subreach of the Lower Arkansas River Basin from Arkansas River at Catlin Dam downstream to Arkansas River near Rocky Ford, Colorado, (A) 2009 and $(B) 2010$. 

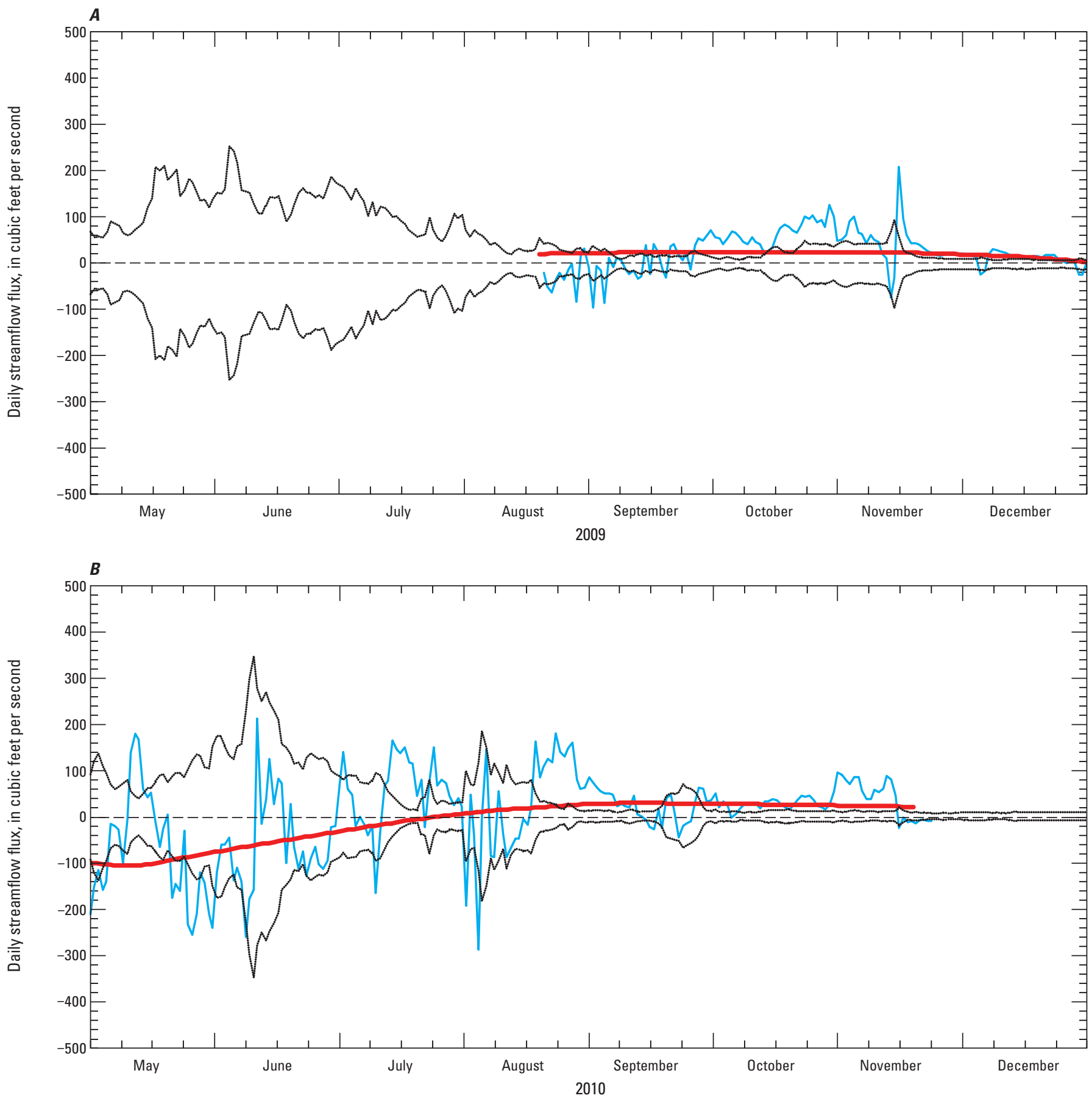

EXPLANATION

Unmeasured streamflow flux

15-percent error bar-The averaged estimated

daily streamflow of the upstream and downstream

main-stem sites in the subreach

LOWESS smoothing curve

Figure 17. Estimated daily gains and losses from unmeasured streamflow along a subreach of the Lower Arkansas River Basin from Arkansas River near Rocky Ford downstream to Arkansas River at La Junta, Colorado, (A) 2009 and (B) 2010. 

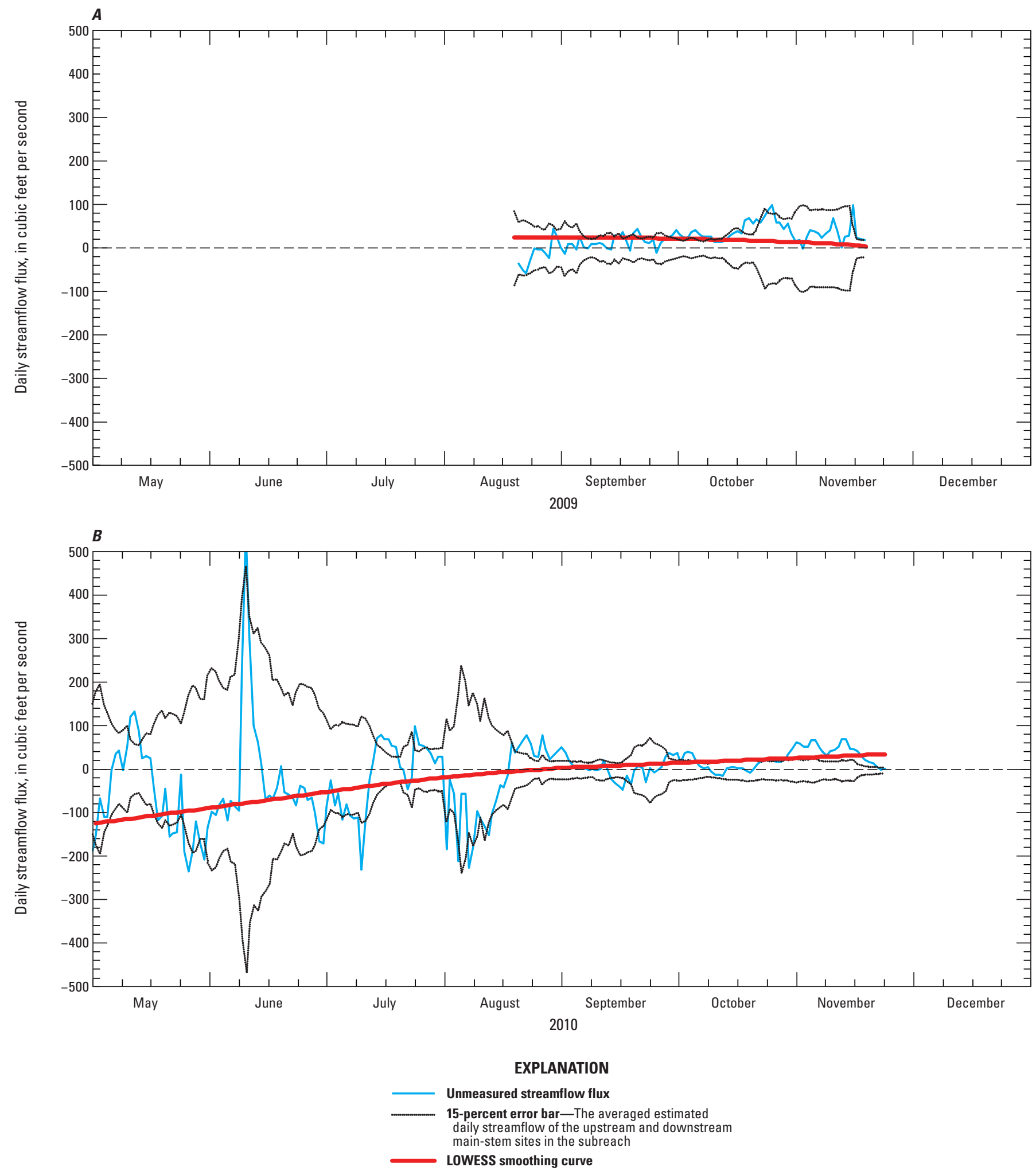

Figure 18. Estimated daily gains and losses from unmeasured streamflow along a subreach of the Lower Arkansas River Basin from Arkansas River near Rocky Ford downstream to Arkansas River at Swink, Colorado, $(A) 2009$ and $(B) 2010$. 

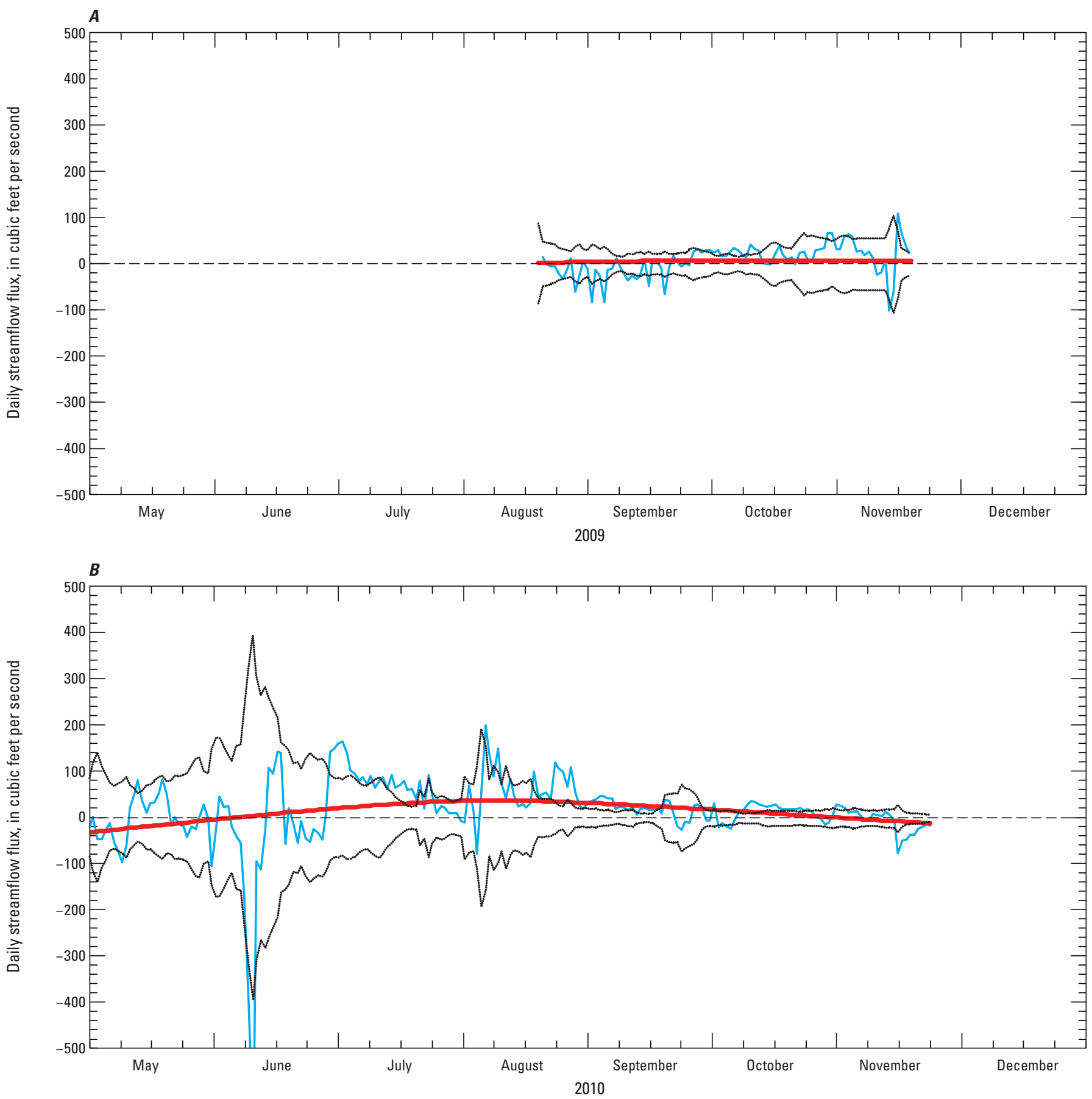

EXPLANATION

Unmeasured streamflow flux

15-percent error bar-The averaged estimated

daily streamflow of the upstream and downstream

main-stem sites in the subreach

LOWESS smoothing curve

Figure 19. Estimated daily gains and losses from unmeasured streamflow along a subreach of the Lower Arkansas River Basin from Arkansas River at Swink downstream to Arkansas River at La Junta, Colorado, (A) 2009 and $(B) 2010$. 
The results of the water-budget analysis along the reach from Ark nr Rocky Ford to Ark at La Junta indicated that there likely was unmeasured surface water and (or) groundwater entering the Arkansas River along this reach. When coupled with the estimated water budgets for the two subreaches of this reach, it appeared that the subreach contributing the unmeasured streamflow flux was most likely the upstream subreach from Ark nr Rocky Ford to Ark at Swink. Additional investigation of this reach would be needed to verify and better quantify the gains from unmeasured sources.

Daily gains and losses from unmeasured streamflow for the 25-mile subreach from Ark at La Junta downstream to Ark at Las Animas during 2009-2010 are shown in figure 20. Estimates were only made for periods when all the seasonal streamflow gages in this subreach were operational. Longterm annual data were available for the main-stem sites, but data for the input sites were seasonal. Streamflow data from one wastewater treatment plant were used to estimate the daily water budget along this subreach (table 1). Other tributaries and diversions are located in this subreach; however, flows were not quantified as part of the study objectives. In 2009 and 2010, estimates of unmeasured streamflow exceeded the 15-percent error bar (unmeasured gains) from mid-November to late December (figs. $20 A$ and 20B). The estimated surfacewater and (or) groundwater gain occurred at a rate of about $1 \mathrm{ft}^{3} / \mathrm{s}$ per river mile.

\section{Potential Unmeasured Sources and Sinks for Streamflow}

In general, the methodology used to quantify streamflow water budgets along the UARB and LARB study reaches accounted for a large percentage of the streamflow. However, the results from the water-budget analyses, as described in the two previous sections of this report, indicated that potential areas of unmeasured sources and sinks of streamflow were identifiable in the two study reaches. Further investigations would be needed to better quantify the gains or losses and to determine the extent of unmeasured surface-water or groundwater inputs, or both, to the river.

In the UARB, a substantial volume of water in the river subreach from Ark at Canon City to the seasonal USGS gaging station 5 miles downstream at Ark nr Canon City was unaccounted for by the methodology used in this analysis (fig. 6). The daily gain from unmeasured sources in this subreach was estimated at about $100 \mathrm{ft}^{3} / \mathrm{s}$ or about $20 \mathrm{ft}^{3} / \mathrm{s}$ per river mile. Water-budget estimates for the remaining 18 miles of the UARB study reach indicated that gains or losses from unmeasured sources and sinks were within the measurement error ( \pm 15 percent) as defined for this report.

In the LARB, the mechanisms and timing for diverting water from the river and for return flows to the river are inherently tied to the irrigation practices of the region. As such, a highly variable water budget was observed in this study reach as daily and even hourly changes in streamflow resulted from reservoir releases and demand for irrigation water. Gains and losses from unmeasured sources and sinks were identified in some of the subreaches but the magnitude of the streamflow flux generally was small. Unmeasured sources ranging from less than 2 to $3 \mathrm{ft}^{3} / \mathrm{s}$ per river mile were identified in the river subreaches from Ark at Catlin Dam downstream to Ark at Swink (figs. 16 and 18). Unmeasured sources of streamflow from La Junta to Las Animas also was evident (fig. 20), but the results could be misleading because known diversions and inputs along this subreach were not quantified; the main focus of the project did not include extensive data collection downstream from Ark at La Junta.

A streamflow loss was indicated along the subreach from Ark at Nepesta to Ark at Catlin Dam, particularly in 2010 (fig. 15). The mechanism and spatial extent of this transmission loss was not identified, and further investigation would be required to better quantify the loss.

\section{Estimation of Gains and Losses in Dissolved-Solids Load from Unmeasured Sources and Sinks}

Dissolved-solids (DS) loads are difficult to measure directly; instead they are computed as the product of DS concentration and streamflow. Direct determination of DS concentration requires an extensive program of sample collection and chemical analysis. DS data for a given streamflow site commonly have been collected at infrequent intervals or do not represent the entire flow regime; however, specific conductance (SC) and streamflow may be measured by automatic monitoring equipment, and their daily-mean values (herein referred to as daily values) routinely are reported for a large number of streamflow sites. If a significant relation is established between SC, DS, and streamflow, then daily DS concentration and loads can be estimated from daily $\mathrm{SC}$ and streamflow values, resulting in reasonably accurate and complete estimates of salinity at the stream location (Liebermann and others, 1986).

DS loads for this report were estimated using several different approaches depending on the type, quantity, and quality of SC, DS, and streamflow data available for each site. Daily DS concentrations were estimated using linear regression relations developed between SC and DS at sites having continuous daily SC and streamflow data as described in Ivahnenko and others (2012). Estimated daily DS concentrations (in $\mathrm{mg} / \mathrm{L}$ ) then were multiplied by daily streamflow $\left(\mathrm{ft}^{3} / \mathrm{sec}\right)$ and a unit conversion factor $(0.0027)$ to obtain daily DS loads in tons per day. This approach was restricted to main-stem sites on the Arkansas River and the Lake Meredith outlet site (table 1).

Estimates of daily $\mathrm{SC}$ at diversion sites were made using linear regression relations developed between discrete SC measurements at or near the diversion head gates and daily $\mathrm{SC}$ measured at nearby continuous water-quality sites on the Arkansas River. Estimates of daily SC were subsequently 

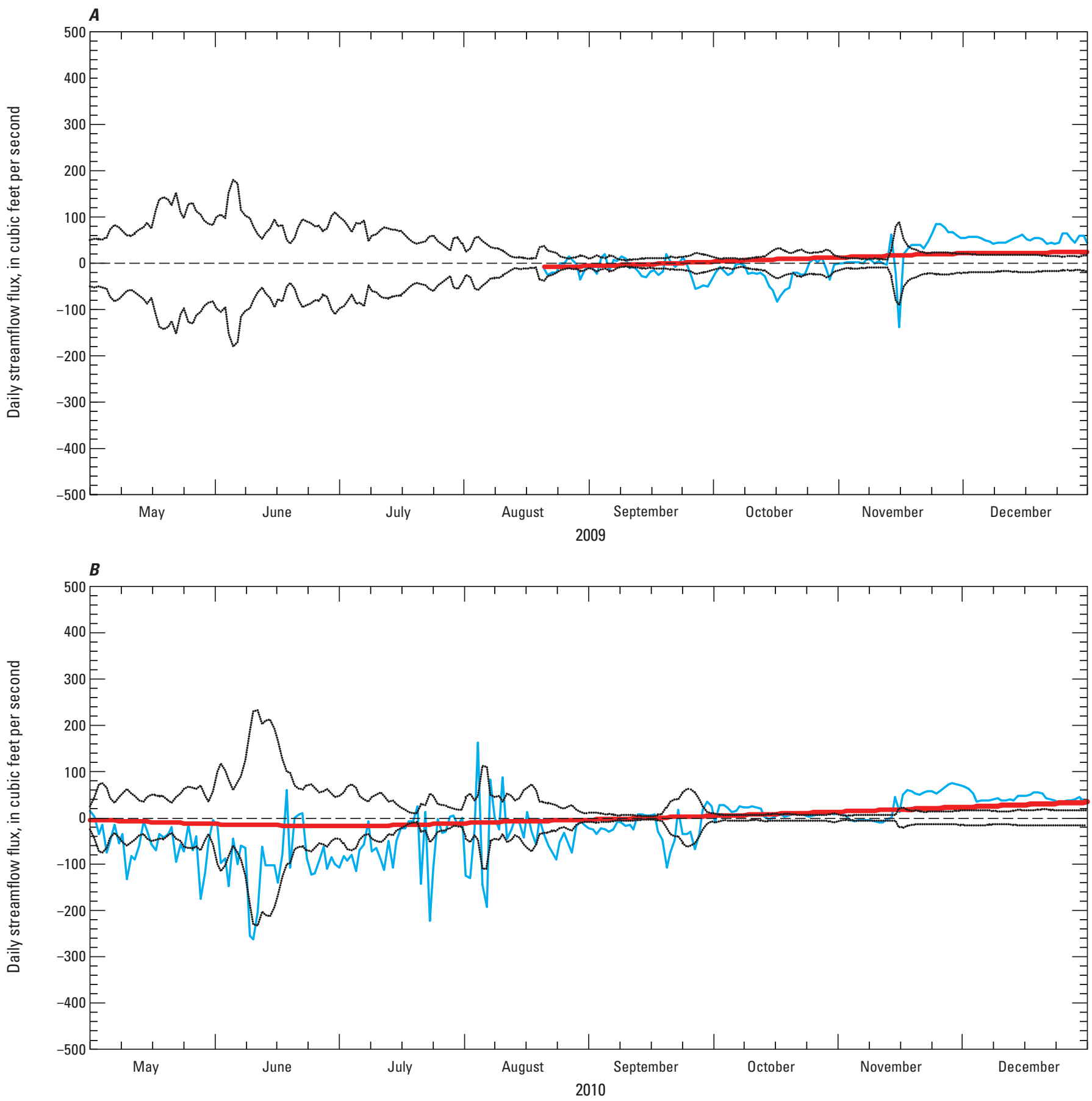

EXPLANATION

Unmeasured streamflow flux

15-percent error bar-The averaged estimated

daily streamflow of the upstream and downstream

main-stem sites in the subreach

LOWESS smoothing curve

Figure 20. Estimated daily gains and losses from unmeasured streamflow along a subreach of the Lower Arkansas River Basin from Arkansas River at La Junta downstream to Arkansas River at Las Animas, Colorado, $(A) 2009$ and $(B) 2010$. 
converted to daily DS concentrations using published regression relations from Ivahnenko and others (2012). Estimated daily DS concentrations and published daily streamflow for the diversions were used to estimate daily loads. As an example, periodic SC measured near the Colorado Canal diversion head gate were linearly related to daily SC values measured at the nearest upstream main-stem site with continuous SC data (in this instance, Ark nr Avondale). A significant relation between the two indicated that the $\mathrm{SC}$ values were 8 percent higher, for the period of record, at the downstream Colorado Canal site. Adjusted estimates of daily SC for Colorado Canal then were converted to estimated daily DS values using published relations for the Ark nr Avondale site. Estimated daily DS concentrations were multiplied by the daily diversion streamflow published for the canal by the State of Colorado to obtain the daily DS loads. The list of regression equations used to estimate $\mathrm{SC}$ at the headgates of selected diversions sampled as part of this study are shown in table 3. In some instances, comparisons made as part of this report utilized relations developed between diversions and seasonal gages, which typically had higher $r$-squared $\left(\mathrm{r}^{2}\right)$ values but were only applicable on a seasonal basis. The coefficient of determination, $\mathrm{r}^{2}$, is a statistical measure of how well the predictive equation (regression line) fits the data points (Helsel and Hirsch, 1992).
Periodic streamflow and SC data were available, at least on a seasonal basis, for most tributary sites sampled as part of this study; however, no continuous SC data were available for any of these tributary sites. As such, daily SC values were estimated for selected sites in both the UARB and LARB reaches using streamflow as the independent variable. Periodic and synoptic sampling for DS concentrations paired with instantaneous SC measurements provided sufficient data to develop regression equations to estimate daily DS concentrations from SC measurements. Finally, DS loads were estimated using daily DS concentrations and daily streamflow data. In selected instances where no continuous streamflow or SC data were available, estimates of daily SC were made using the median value of all periodic measurements made at a site. Linear regressions were developed to estimate DS concentrations from paired SC measurements collected during the study period. As such, median DS concentrations were defined for each of the sites. A median streamflow value was calculated from all instantaneous measurements made at a site, and this value was used to calculate a daily DS load. Typically, this methodology to determine DS loads only was used on small tributaries where mass loading was expected to be relatively small.

Table 3. Estimation of daily specific conductance at selected diversion structures using linear regression equations relating specific conductance at main-stem sites in the Arkansas River Basin in Colorado with data for long-term continuous specific-conductance monitors, 2009-2010.

[SC, specific conductance in microsiemens per centimeter; na, not available]

\begin{tabular}{|c|c|c|c|}
\hline Site & Regression equation & $\begin{array}{c}\text { Number of } \\
\text { comparisons }\end{array}$ & $\begin{array}{c}\text { Coefficient of } \\
\text { determination }\left(\mathrm{r}^{2}\right)\end{array}$ \\
\hline \multicolumn{4}{|c|}{ Upper Arkansas River Basin study reach } \\
\hline Canon City and Oil Creek Ditch ${ }^{1}$ & $\mathrm{SC}=\left(1.00 \times \mathrm{SC}_{\text {Ark at Canon City }}\right)$ & na & na \\
\hline Fremont Ditch ${ }^{1}$ & $\mathrm{SC}=\left(1.00 \times \mathrm{SC}_{\text {Ark at Canon City }}\right)$ & na & na \\
\hline Minnequa Canal ${ }^{2}$ & $\mathrm{SC}=\left(1.53 \times \mathrm{SC}_{\text {Ark at Canon City }}\right)-59$ & na & 0.94 \\
\hline \multicolumn{4}{|c|}{ Lower Arkansas River Basin study reach } \\
\hline Collier Ditch ${ }^{1}$ & $\mathrm{SC}=\left(1.00 \times \mathrm{SC}_{\text {Ark nr Avondale }}\right)$ & na & na \\
\hline Colorado Canal & $\mathrm{SC}=\left(1.08 \times \mathrm{SC}_{\text {Ark nr Avondale }}\right)-.4$ & 16 & 0.97 \\
\hline Highline Canal & $\mathrm{SC}=\left(1.12 \times \mathrm{SC}_{\text {Ark nr Avondale }}\right)+20$ & 35 & 0.90 \\
\hline Oxford Canal & $\mathrm{SC}=\left(1.07 \times \mathrm{SC}_{\text {Ark nr Avondale }}\right)+38$ & 34 & 0.95 \\
\hline Otero Canal & $\mathrm{SC}=\left(1.11 \times \mathrm{SC}_{\text {Ark at Catlin Dam }}\right)-60$ & 32 & 0.73 \\
\hline Catlin Canal $^{1}$ & $\mathrm{SC}=\left(1.00 \times \mathrm{SC}_{\text {Ark at Catlin Dam }}\right)$ & na & na \\
\hline Holbrook Ditch & $\mathrm{SC}=\left(0.85 \times \mathrm{SC}_{\text {Ark at Catlin Dam }}\right)+108$ & 20 & 0.84 \\
\hline Rocky Ford Ditch & $\mathrm{SC}=\left(1.09 \times \mathrm{SC}_{\text {Ark at Catlin Dam }}\right)+119$ & 34 & 0.77 \\
\hline Ft. Lyon Storage Canal & $\mathrm{SC}=\left(0.82 \times \mathrm{SC}_{\text {Ark at Catlin Dam }}\right)+225$ & 11 & 0.81 \\
\hline Ft. Lyon Canal & $\mathrm{SC}=\left(1.36 \times \mathrm{SC}_{\text {Ark at Catlin Dam }}\right)+51$ & 33 & 0.62 \\
\hline
\end{tabular}

\footnotetext{
${ }^{1}$ Due to proximity, specific-conductance values were assumed to be the same as the upstream main-stem site with a long-term data-collection record.

${ }^{2}$ Estimation of specific conductance at this site was assumed to be the same as Arkansas River near Canon City, which was linearly related to the upstream main-stem site with a long-term data-collection record.
} 
When applied to a defined reach, the quantity of DS load attributable to unmeasured sources or sinks (the flux in load) can be estimated as

$$
\operatorname{Load}_{\text {flux }}=\operatorname{Load}_{\mathrm{ds}}-\operatorname{Load}_{\text {us }}+\sum \operatorname{Load}_{\text {out }}-\sum \operatorname{Load}_{\text {in }}
$$

where

$$
\begin{aligned}
& \text { Load }_{\mathrm{ds}} \text { is the DS load at the downstream } \\
& \text { end of the subreach, } \\
& \text { Load }_{\text {us is the DS load at the upstream end }} \\
& \text { of the subreach, } \\
& \text { LOAD out are DS load outputs from the } \\
& \text { subreach such as diversions, and }_{\text {Load }_{\text {in }} \text { are DS load inputs to the reach such }} \\
& \text { as tributaries or sewage outfalls. }
\end{aligned}
$$

As such, a positive Load $_{\text {flux }}$ indicates a net gain to the reach in the form of unmeasured DS load from groundwater or unmeasured surface-water inputs. A negative $\operatorname{Load}_{\text {flux }}$ indicates a net loss of DS load to the groundwater system, unmeasured diversions, or other potential sinks.

Given the inherent uncertainties associated with the data needed to calculate DS mass loading on the Arkansas River, error bars were applied to evaluate the level of reasonableness of the load estimations. In order to have confidence in the identification of river subreaches where stream-aquifer interactions could have a pronounced effect on water quality, the magnitude of the flux had to exceed the magnitude of the inherent uncertainties of the measurement errors. For the purposes of this report, error bars of \pm 20 percent of the averaged estimated daily DS loads of the upstream and downstream main-stem sites within a subreach were calculated to help evaluate the results. Given that the streamflow error in this analysis was set at \pm 15 percent, a value of \pm 20 percent was considered to be sufficiently conservative given potential analytical error associated with DS analysis and estimation techniques for DS concentrations at some sites.

\section{Gains and Losses in Dissolved-Solids Load in the Upper Arkansas River Basin Study Reach}

Miller and others (2010) reported that DS concentrations increased substantially downstream from Canon City (based on data from 1976 through 2007); median DS concentrations increased by 138 percent from Canon City to the outlet of Pueblo Reservoir. Median DS concentrations increased by as much as 78 percent along a shorter 16-mile subreach from Ark at Canon City to Ark at Portland. The increase in DS concentrations was attributed to changes in geology and chemical composition of rocks and increased irrigation return flows (Miles, 1977; Cain, 1987).

Similarly, average annual DS loads increased substantially between Canon City and the outlet of Pueblo Reservoir with the largest increase occurring between Canon City and Portland. Based on data from January 1995 through December 2006, average annual DS loads increased
72 percent from Ark at Canon City (82,700 tons per year) to Ark at Portland (142,000 tons per year). During the same period, the Minnequa Canal diverted an average of about 18,700 tons per year of DS loads from the river between these two sites (Miller and others, 2010). As such, more than half of the average annual DS loads observed at Ark at Portland entered the Arkansas River between Canon City and Portland.

\section{Canon City to Portland}

Estimated daily gains and losses in dissolved-solids load for the 16-mile river subreach from Ark at Canon City downstream to Ark at Portland during 2009-2010 are shown in figure 21. Estimates only were calculated for those periods when all the seasonal water-quality monitors in this subreach were operational. Estimates of daily DS loads in 2009 and 2010 indicated that unaccounted gains in DS load exceeded the 20-percent error bar during nearly all of the periods of data collection (figs. $21 A$ and $21 B$ ). In 2009, the magnitude of the gains in DS load in the Arkansas River sloped downward with respect to time and varied from 138 tons per day in August to 64 tons per day in December. Given that the study reach was approximately 16 miles in length, the daily unaccounted DS load flux was estimated to range from 4 to 8.6 tons per day per river mile. In 2010, the gain in load was more consistent varying from 123 to 112 tons per day during the same time frame; the daily unaccounted DS load flux was estimated to range from 7 to 7.7 tons per day per river mile. These results indicate that unmeasured gains in DS load entered the river along this subreach.

Additional spatial definition was available along this reach because an intermediate site between Canon City and Portland was operational during the study period. The site, Ark nr Canon City, was selected as an intermediate site to help identify potential source areas along the longer river reach. The following discussion describes the characteristics of gains and losses in DS load for the subreaches Ark at Canon City to Ark nr Canon City and from Ark nr Canon City to Ark at Portland.

The estimates of unaccounted gains and losses in DS load in the 5-mile subreach from Ark at Canon City downstream to Ark nr Canon City (fig. 22) appeared to be similar to those observed along the longer study reach from Ark at Canon City downstream to Ark at Portland (fig. 21). Estimates of DS load flux in 2009 and 2010 indicated that unaccounted gains exceeded the 20-percent error bar during most of the data-collection period (figs. $22 A$ and $22 B$ ). In 2009, the magnitude of the gains (represented by the LOWESS line) sloped downward and varied from 110 tons per day in August to 55 tons per day in December; the daily unaccounted gain in DS load was estimated to range from 11 to 22 tons per day per river mile. In 2010, the gain was mostly consistent varying from 65 to 40 tons per day. The daily unaccounted DS load flux was estimated to range from about 8 to 13 tons per day 

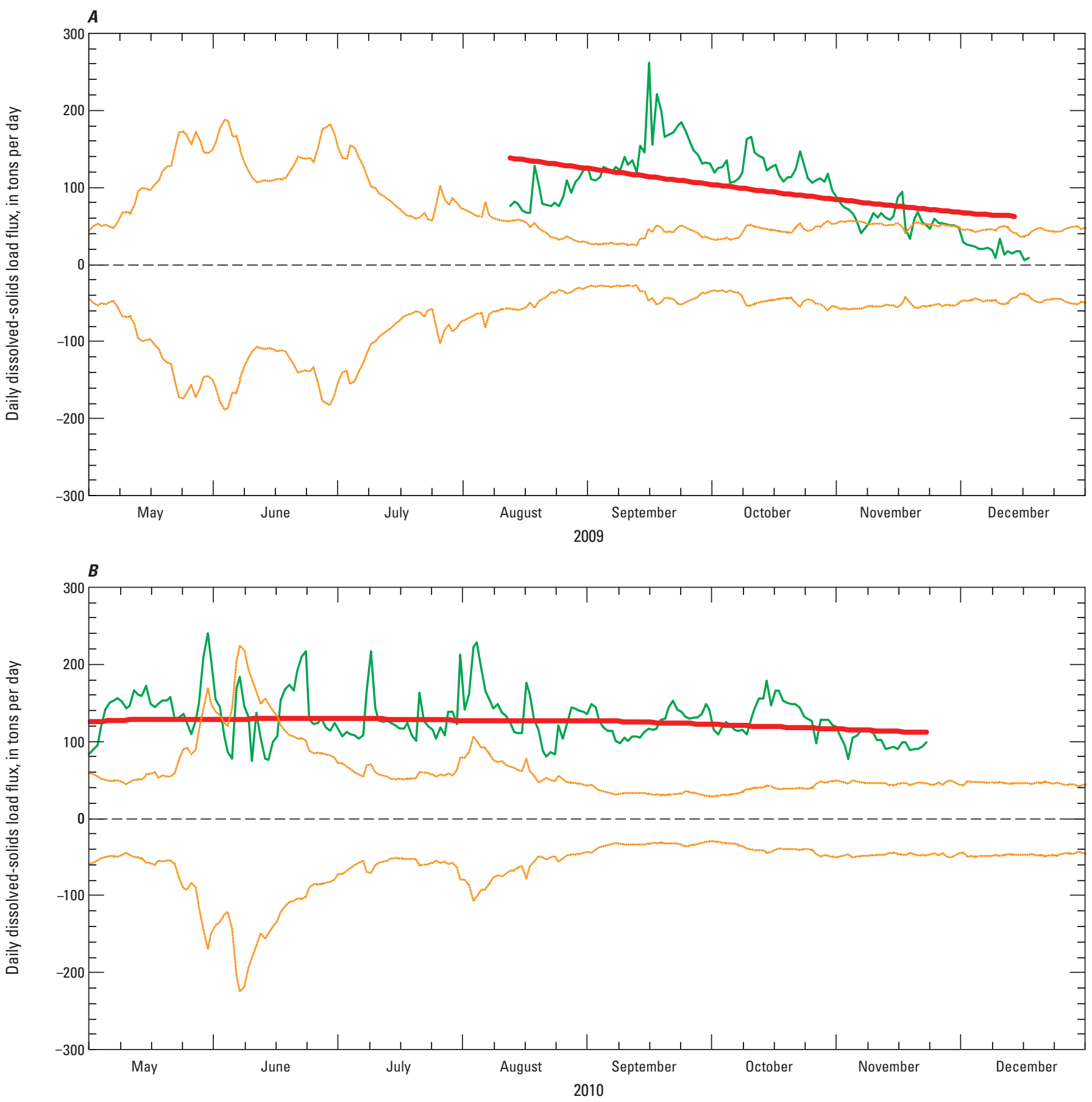

\section{EXPLANATION}

Dissolved-solids load flux

20-percent error bar-The averaged estimated daily dissolved-solids load of the upstream and downstream main-stem sites in the subreach

LOWESS smoothing curve

Figure 21. Estimated daily gains and losses in dissolved-solids load along a subreach of the Upper Arkansas River Basin from Arkansas River at Canon City downstream to Arkansas River at Portland, Colorado, (A) 2009 and (B) 2010. 

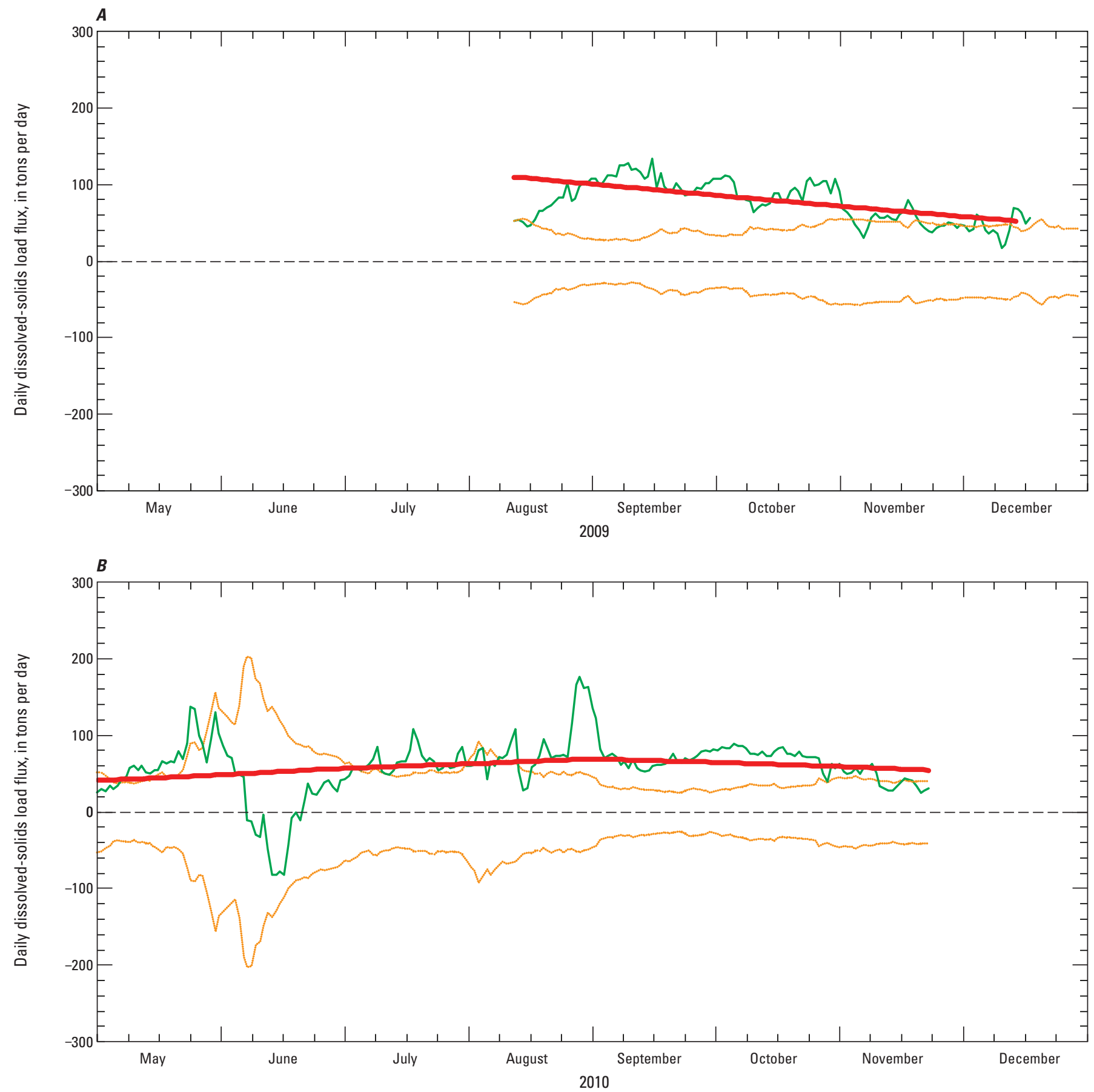

EXPLANATION

Dissolved-solids load flux

20-percent error bar-The averaged estimated daily dissolved-solids load of the upstream and downstream main-stem sites in the subreach

LOWESS smoothing curve

Figure 22. Estimated daily gains and losses in dissolved-solids load along a subreach of the Upper Arkansas River Basin from Arkansas River at Canon City downstream to Arkansas River near Canon City, Colorado, $(A) 2009$ and $(B) 2010$. 
per river mile along the 5-mile subreach. These results indicate that unaccounted sources of DS load exist along this subreach. Overall, these results might be expected given that $20 \mathrm{ft}^{3} / \mathrm{s} \mathrm{per}$ mile of unmeasured streamflow flux was estimated to have entered the river along this subreach. If the gains in DS load were spatially consistent, inputs of about $400 \mathrm{mg} / \mathrm{L}$ would be needed to account for the 22 tons per day per mile of increased DS load. Miller and others (2010) reported that the median DS concentration in the river at Ark at Canon City between 1970 and 2009 was $143 \mathrm{mg} / \mathrm{L}$.

Estimated daily gains and losses in DS load for the 11-mile river subreach from Ark nr Canon City downstream to Ark at Portland during 2009-2010 are shown in figure 23. In 2009, estimated gains and losses in DS load did not exceed the 20-percent error bar (fig. 23A). In 2010, the estimates of unaccounted gains exceeded the error bar in May, briefly in July, and from September through November (fig. 23B). The magnitude of the unaccounted gains in DS load in 2010 was similar to the gains observed in the upstream subreach from Ark at Canon City to Ark nr Canon City; the flux ranged from 84 tons per day in May to 59 tons per day in November along the subreach. The daily unaccounted gain in DS load was estimated to range from 5.4 to 7.6 tons per day per river mile.

Analysis of the water budget indicated little evidence to suggest that unmeasured streamflow flux along this subreach could be quantified (fig. 7), yet there appeared to be a source of DS load to the river. Ivahnenko and others (2012) reported numerous small tributaries with high DS concentrations downstream from Florence, Colo. In some of these tributaries, DS concentrations were in excess of $3,000 \mathrm{mg} / \mathrm{L}$. Although DS loading was relatively small, the tributaries may be indicators of substantial groundwater inputs along this reach of the river with high DS concentrations. Additional information pertaining to groundwater interactions with the river is needed to address these results.

\section{Portland to Pueblo Reservoir}

Estimated daily gains and losses in dissolved-solids load for the 7-mile river subreach from Ark at Portland downstream to Ark nr Portland, which is near the upper end of Pueblo Reservoir, are shown in figure 24. Estimates only were calculated for those periods when all the seasonal water-quality monitors in this subreach were operational. In 2009 , the estimated unaccounted gain in DS load increased through the estimation period and ultimately exceeded the 20-percent threshold from early November through December (fig. 24A). The magnitude of the unaccounted load flux in 2009 ranged from 77 tons per day in early November to 110 tons per day in late December along the subreach; the daily unaccounted gain in DS load was estimated to range from 11 to 16 tons per day per river mile. In 2010, the LOWESS line was relatively unchanged from near the zero line and estimates of DS load flux did not exceed the 20-percent error bar at any time (fig. 24B).
Previous analysis of the water budget provided little evidence to suggest that unmeasured gains or losses in streamflow could be quantified along this subreach in 2009; however, there appeared to be an increase in unaccounted DS load to the river in November and December of 2009. A similar occurrence was not observed in 2010. The contradicting results for the 2 years are difficult to interpret and further investigation of groundwater inputs along this reach may be warranted given the potential for high DS concentrations in the groundwater; Ivahnenko and others (2012) reported numerous small tributaries along this reach of the river with DS concentrations that ranged from about $2,000 \mathrm{mg} / \mathrm{L}$ to as high as $6,000 \mathrm{mg} / \mathrm{L}$. DS concentrations in this reach of the river in November and December typically were about $400 \mathrm{mg} / \mathrm{L}$.

\section{Gains and Losses in Dissolved-Solids Load in the Lower Arkansas River Basin Study Reach}

Miller and others (2010) reported that DS concentrations in the Arkansas River increased downstream by more than 634 percent from Avondale to the Colorado-Kansas Stateline. The largest increase in median DS concentration (46 percent) in the LARB study reach occurred between Rocky Ford and La Junta. Typically, DS concentrations were lower during the irrigation season (March-October) than during the nonirrigation season (November through February). DS loads, however, were higher during the irrigation season because streamflows were much higher during this time. Miller and others (2010) reported that DS loads can be as much as 23 times higher during the irrigation season. Average annual DS loads (2000-2006) in the Arkansas River increased by about 30 percent between Ark nr Avondale and a streamflow gage downstream from John Martin Reservoir (USGS station 07130500 ) (fig. 1). Within the LARB study reach, however, average annual DS loads decreased substantially from Ark nr Avondale to Ark at Catlin Dam (21 percent) and from Ark at Catlin Dam to Ark at Las Animas (31 percent). The only increase in average annual load occurred between Las Animas and the outlet of John Martin Reservoir.

\section{Avondale to Catlin Dam}

Estimated daily gains and losses in DS load for the 21-mile river subreach from Ark nr Avondale downstream to Ark at Nepesta during 2009-2010 are shown in figure 25. Estimates only were calculated for those periods when all the seasonal water-quality monitors in this subreach were operational. In 2009, estimates of daily DS loads indicated that unaccounted gains or losses in DS load only exceeded the 20-percent error bar during short periods in August, September, and October (fig. 25A). Although the error bars were not exceeded during most other times in 2009, the LOWESS line was relatively level and averaged about 100 tons per day. The estimated daily gain in DS load was 

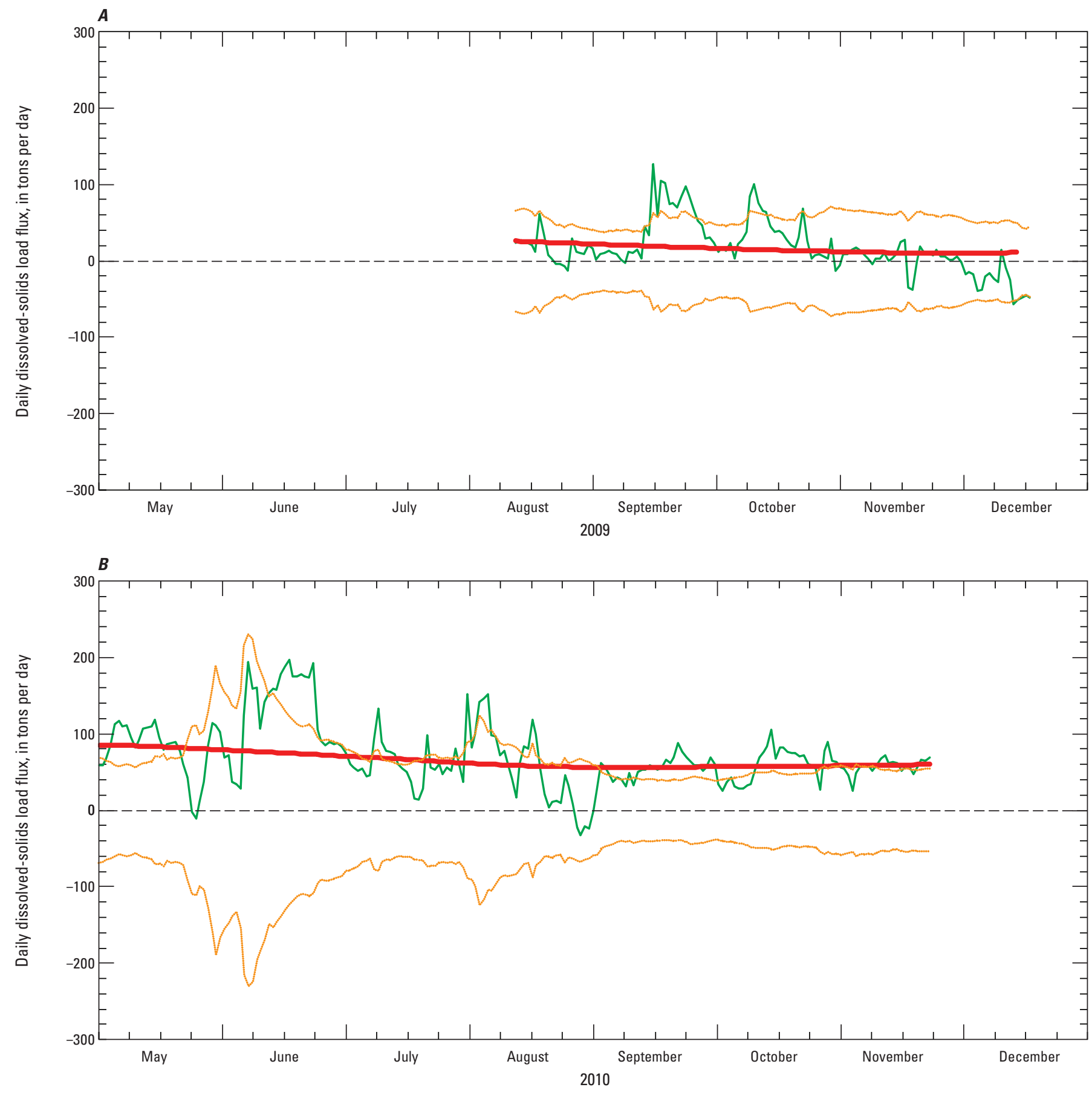

EXPLANATION

Dissolved-solids load flux

20-percent error bar-The averaged estimated daily dissolved-solids load of the upstream and downstream main-stem sites in the subreach

LOWESS smoothing curve

Figure 23. Estimated daily gains and losses in dissolved-solids load along a subreach of the Upper Arkansas River Basin from Arkansas River near Canon City downstream to Arkansas River at Portland, Colorado, $(A) 2009$ and $(B) 2010$. 

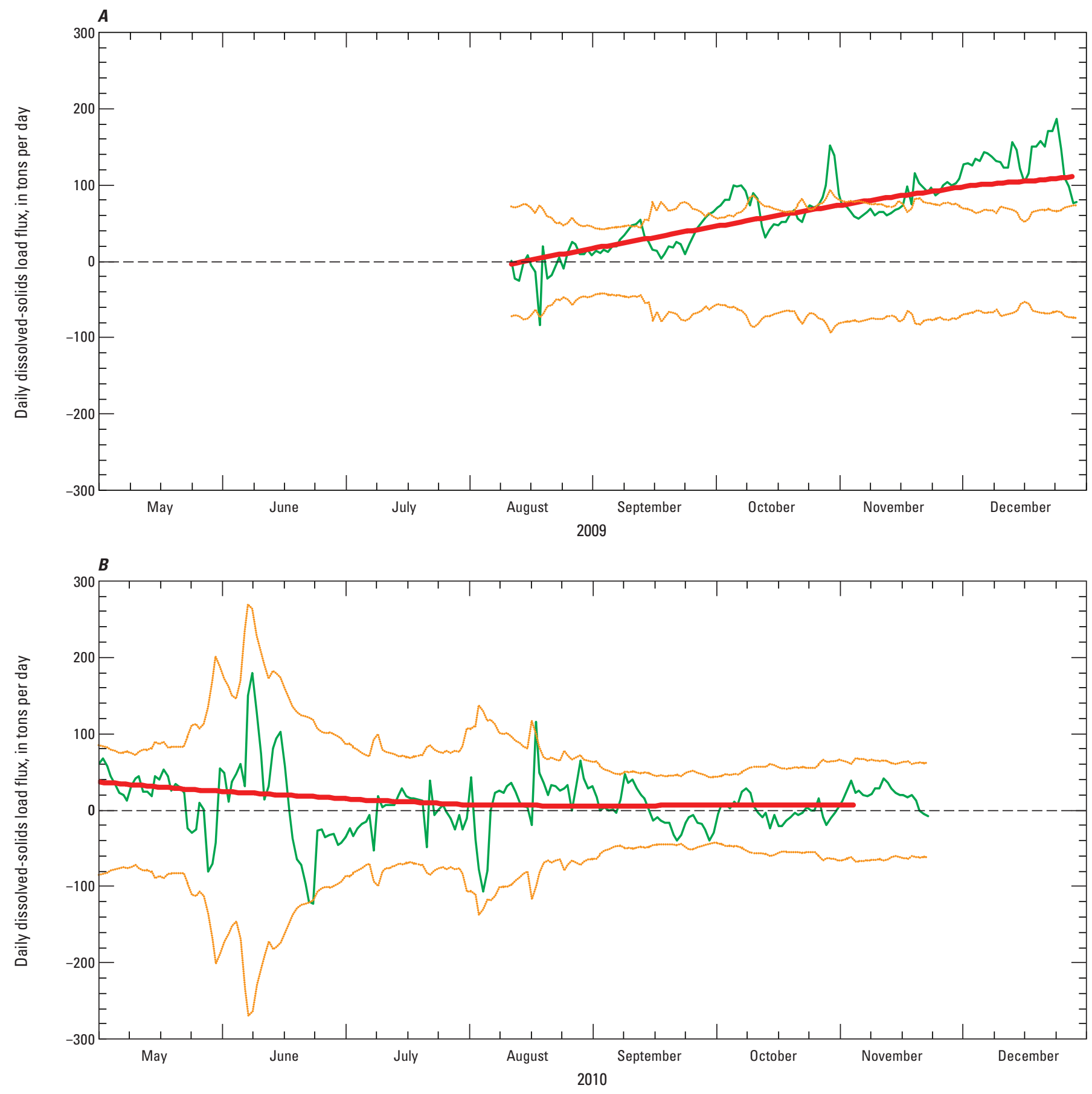

EXPLANATION

Dissolved-solids load flux

20-percent error bar-The averaged estimated daily dissolved-solids load of the upstream and downstream main-stem sites in the subreach

LOWESS smoothing curve

Figure 24. Estimated daily gains and losses in dissolved-solids load along a subreach of the Upper Arkansas River Basin from Arkansas River at Portland downstream to Arkansas River near Portland, Colorado, $(A) 2009$ and $(B) 2010$. 

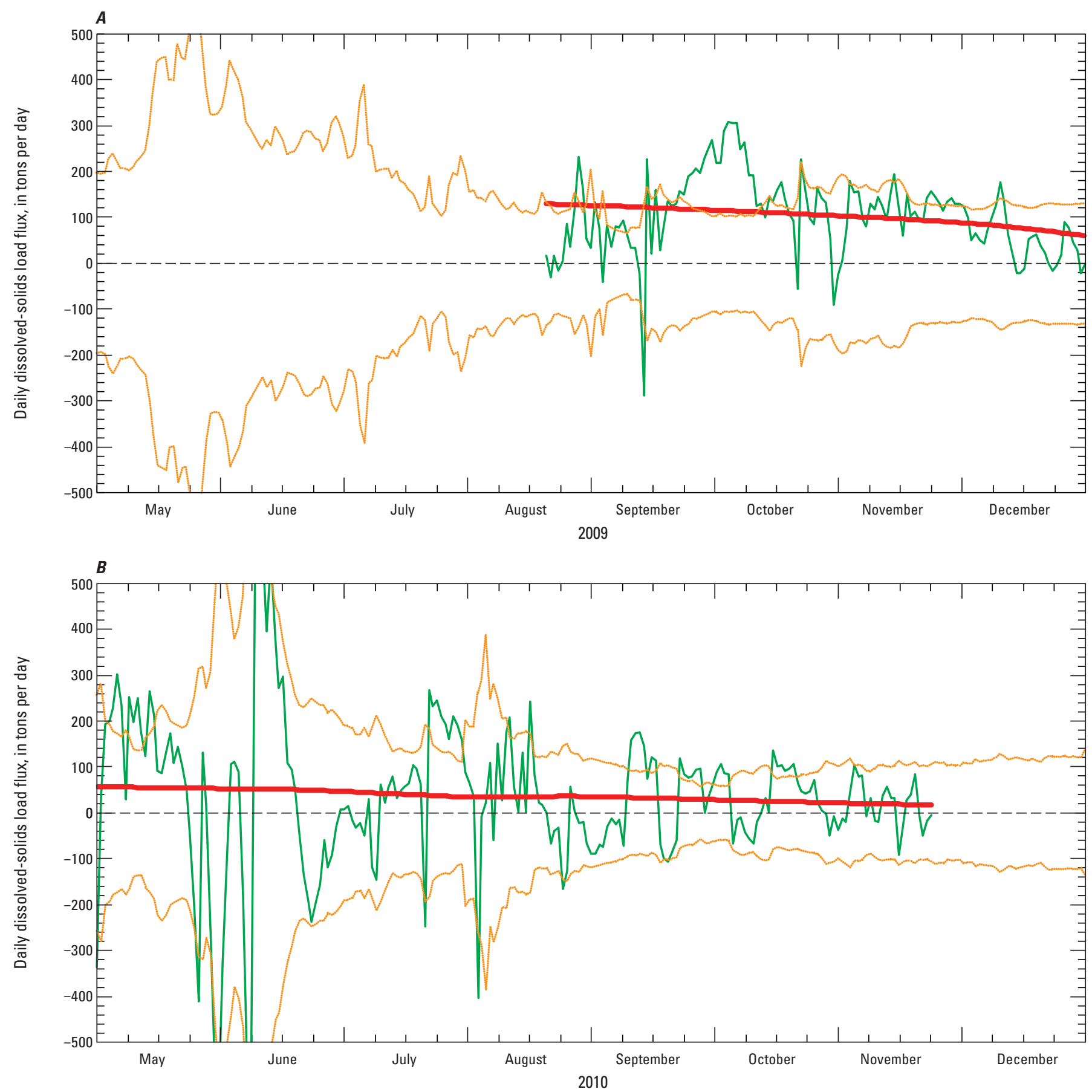

EXPLANATION

Dissolved-solids load flux

20-percent error bar-The averaged estimated daily dissolved-solids load of the upstream and downstream main-stem sites in the subreach

LOWESS smoothing curve

Figure 25. Estimated daily gains and losses in dissolved-solids load along a subreach of the Lower Arkansas River Basin from Arkansas River near Avondale downstream to Arkansas River at Nepesta, Colorado, $(A) 2009$ and $(B) 2010$. 
4.7 tons per day per river mile. Estimates of DS loads in 2010 indicated that unmeasured DS loads did not exceed the 20 -percent error bar at any time (fig $25 B$ ). It is important to note that estimates of DS load flux in 2010 included a highflow period from May through July that were not represented in any of the 2009 estimates.

Estimated daily gains and losses in DS load for the 15-mile river subreach from Ark at Nepesta downstream to Ark at Catlin Dam during 2009-2010 are shown in figure 26. Estimates only were calculated for those periods when all the seasonal water-quality monitors in this subreach were operational. Estimates of daily DS loads in 2009 indicated that unmeasured gains in DS load only exceeded the upper 20-percent error bar during short periods in December (fig. 26A). In 2010, a contrasting flux profile was observed as a net loss of DS load along the subreach was observed from mid-September until late November (fig. 26B). The magnitude of the losses ranged from about 90 tons per day in September to more than 300 tons per day by late November. The mechanism and spatial extent of the losses in DS load were not specifically identified, and further investigation would be required to better quantify the losses.

\section{Catlin Dam to Las Animas}

Miller and others (2010) computed average annual streamflow, DS concentration, and DS loads for numerous main-stem sites for a 6-year period from 2000 to 2006. Estimates for the sites Ark at Catlin Dam and Ark at Las Animas were included in their analysis. Overall, there was a substantial increase in DS concentrations from Catlin Dam to Las Animas as irrigation return flows entered the river (Miller and others, 2010). Correspondingly, a decrease in streamflow occurred along this reach of the river as large quantities of water were continually diverted from the river. The overall result was a 31-percent decrease in the average annual DS load between these two sites (from 238,540 to 164,685 tons per year).

Estimated daily gains and losses on DS load for the 20-mile river subreach from Ark at Catlin Dam downstream to the next main-stem site, Ark nr Rocky Ford, are shown in figure 27. Estimates only were calculated for those periods when all the seasonal water-quality monitors in this subreach were operational. In 2009, daily estimates of DS load indicated that unmeasured gains in DS load exceeded the upper 20-percent error bar during most of the estimation period with the exception of a short period in late October through mid-November (fig. 27A). Although the error bars were not exceeded all the time in 2009, the LOWESS line was relatively level and averaged about 200 tons per day; the daily unmeasured DS load flux along this subreach was estimated at 10 tons per day per river mile. In 2010, the LOWESS line was much more variable with a decreasing slope throughout the estimation period particularly during the high-flow period in the summer months (fig. 27B). Overall, the LOWESS line exceeded the 20-percent error bar for much of this time. These results indicate that unmeasured gains in DS load entered the river along this subreach, particularly in 2009.

Estimated daily gains and losses in DS load for the 6.3-mile river subreach from Ark nr Rocky Ford downstream to Ark at Swink during 2009-2010 are shown in figure 28. Estimates only were calculated for those periods when all the seasonal water-quality monitors in this subreach were operational; the site at Swink was the only main-stem site in the LARB where continuous streamflow and SC monitoring were operated on a seasonal basis. Estimates of daily DS loads in 2009 indicated that unmeasured gains in DS load only exceeded the upper 20-percent error bar from September through mid-October (fig. 28A). However, the LOWESS line was relatively level and averaged about 175 tons per day or about 28 tons per day per river mile. In 2010, the LOWESS line exceeded the upper error bar from mid-October through November (fig. 28B). Unmeasured gains during this period were about 30 percent lower than those observed in 2009.

Estimated daily gains and losses in dissolved-solids load for the 6.8-mile river subreach from Ark at Swink downstream to Ark at La Junta during 2009-2010 are shown in figure 29. Estimates only were calculated for those periods when all the seasonal water-quality monitors in this subreach were operational. Estimates of daily DS loads indicated that unmeasured gains and losses in DS load did not exceed the 20-percent error bar for any extended period in 2009 or 2010 (figs. 29A and 29B). This subreach of the Arkansas River is a relatively short distance with only one tributary input. The site at Swink was originally selected as a monitoring site to subdivide the subreach from Rocky Ford to La Junta because Miller and others (2010) had indicated that the largest percentage increase in median DS concentrations between Pueblo Reservoir and John Martin Reservoir occurred between these two sites. However, no substantial unmeasured gains or losses in DS load were observed in this subreach by this analysis.

Estimated daily gains and losses in DS load for the 25-mile river subreach from Ark at La Junta downstream to Ark at Las Animas during 2009-2010 are shown in figure 30. Estimates only were calculated for those periods when all the seasonal water-quality monitors in this subreach were operational. Estimates of DS loads in 2009 indicated that unmeasured gains in DS load exceeded the upper 20-percent error bar for most of November through December (fig. 30A). In 2009, the LOWESS line was variable with an upward slope throughout the estimation period. In 2010, the LOWESS line exceeded the 20-percent error bar for much of the time after the high-flow period ended in August (fig. 30B). Although the error bars were not exceeded all the time in 2010, the LOWESS line was relatively level and averaged about 100 tons per day during most of the analysis period; the daily unmeasured load flux along the reach was estimated at 4 tons per day per river mile. It should be noted that estimates along this 25-mile reach did not include any estimates of inflow loads other than the La Junta wastewater effluent, because the focus of much of the data-collection activities in the LARB 

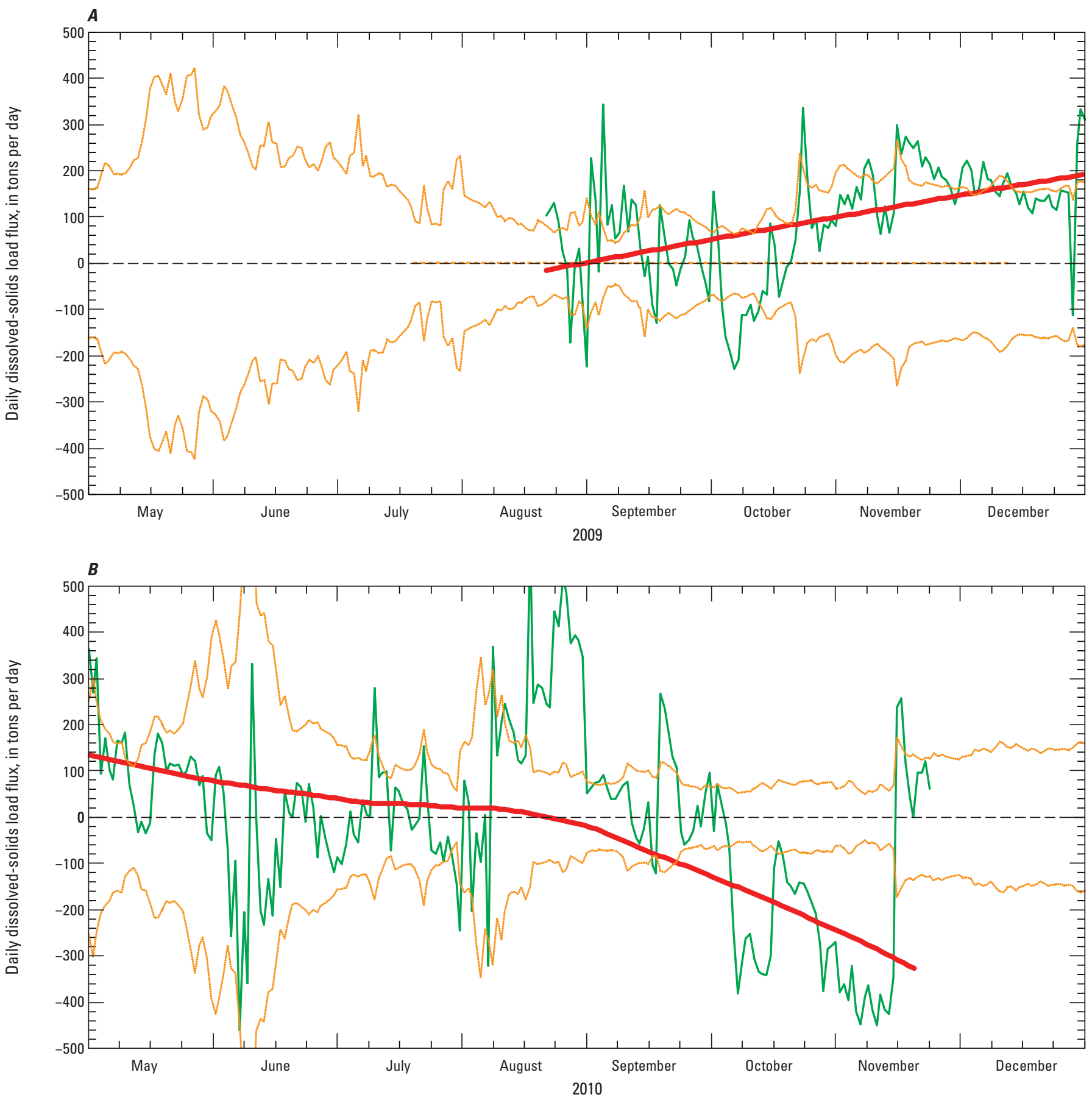

EXPLANATION

Dissolved-solids load flux

20-percent error bar-The averaged estimated daily dissolved-solids load of the upstream and downstream main-stem sites in the subreach

LOWESS smoothing curve

Figure 26. Estimated daily gains and losses in dissolved-solids load along a subreach of the Lower Arkansas River Basin from Arkansas River at Nepesta downstream to Arkansas River at Catlin Dam, Colorado, $(A) 2009$ and $(B) 2010$. 

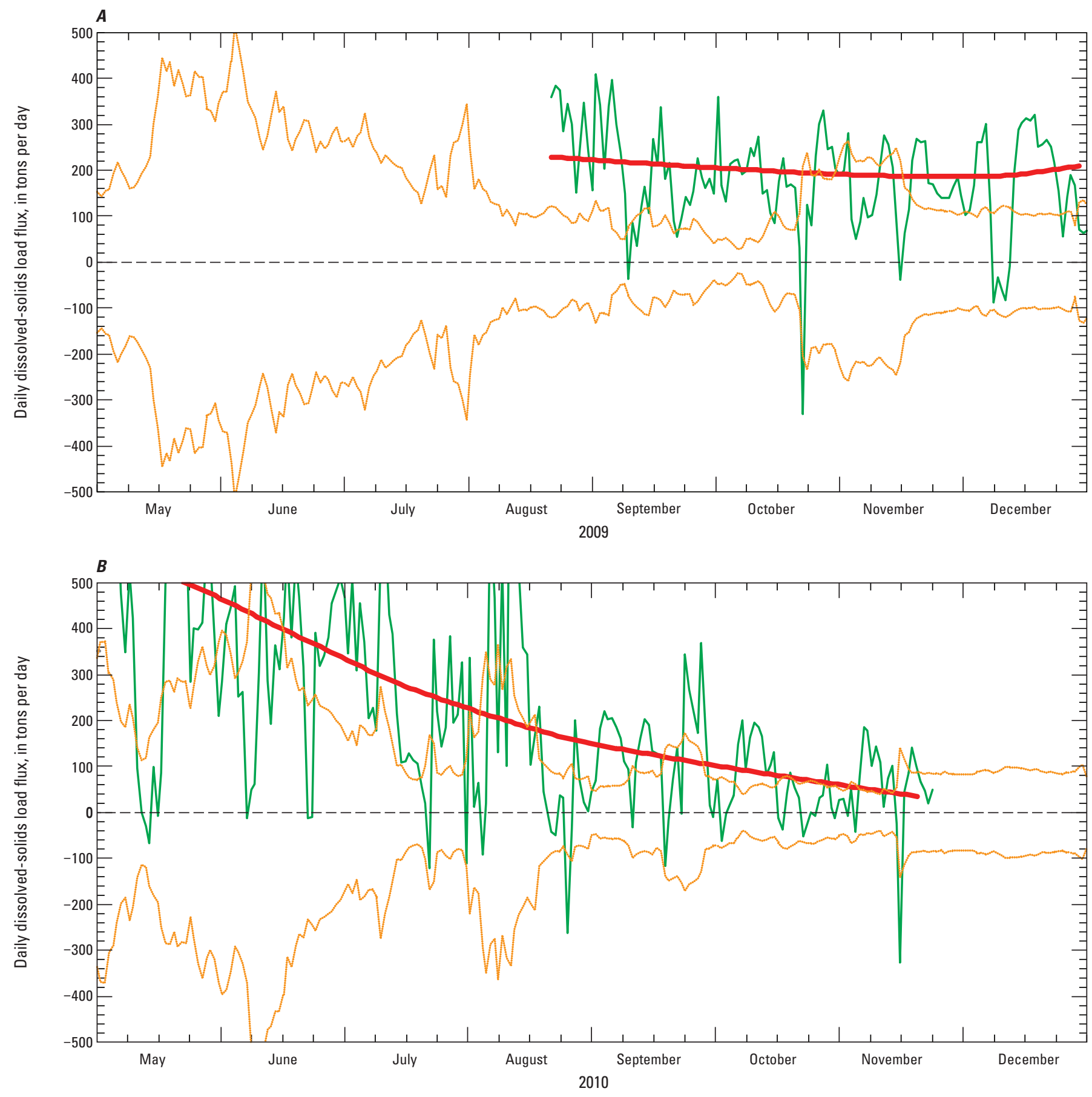

EXPLANATION

Dissolved-solids load flux

20-percent error bar-The averaged estimated daily dissolved-solids load of the upstream and downstream main-stem sites in the subreach

LOWESS smoothing curve

Figure 27. Estimated daily gains and losses in dissolved-solids load along a subreach of the Lower Arkansas River Basin study area from Arkansas River at Catlin Dam downstream to Arkansas River near Rocky Ford, Colorado, (A) 2009 and (B) 2010. 

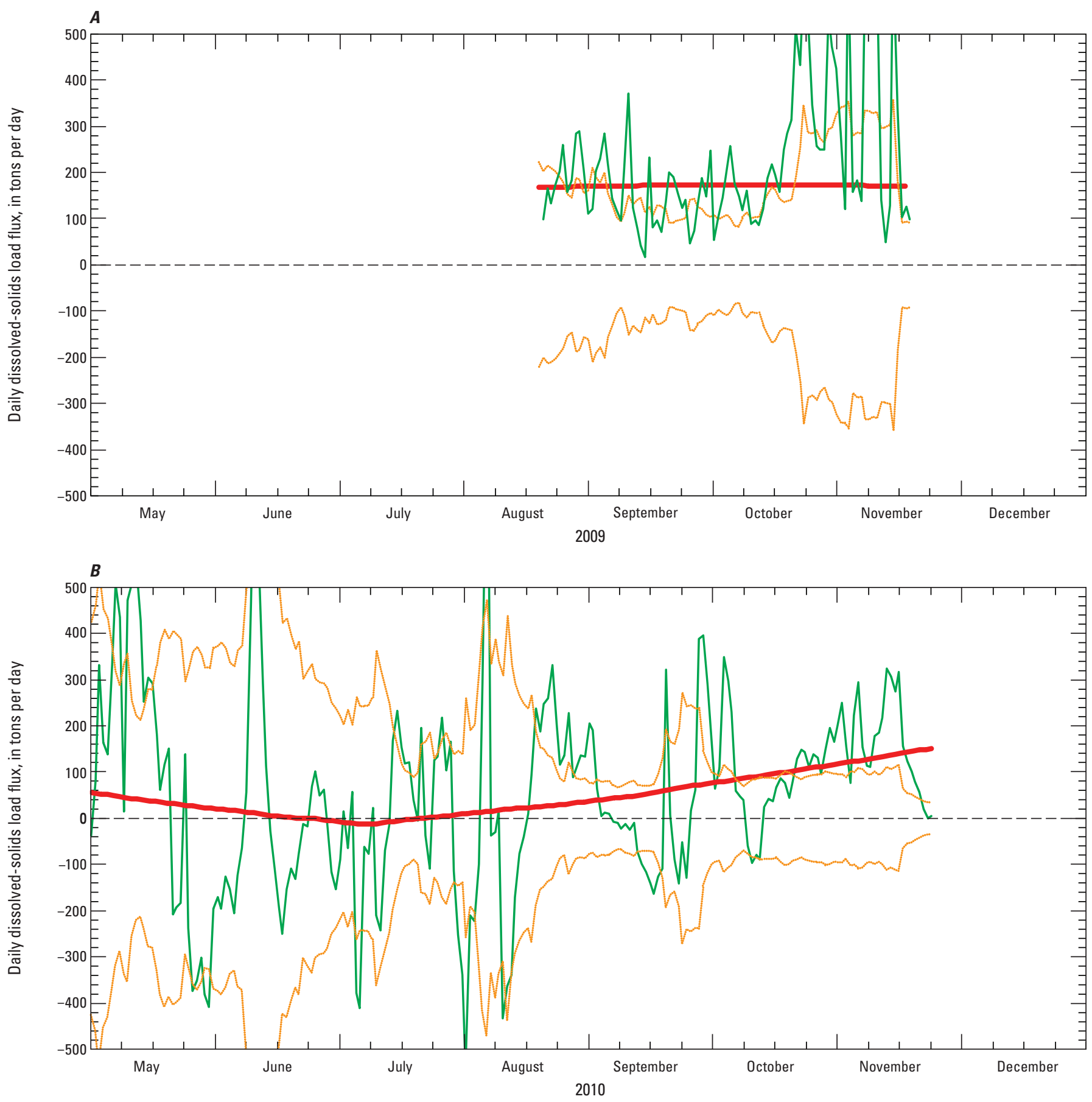

EXPLANATION

Dissolved-solids load flux

20-percent error bar-The averaged estimated daily dissolved-solids load of the upstream and downstream main-stem sites in the subreach

LOWESS smoothing curve

Figure 28. Estimated daily gains and losses in dissolved-solids load along a subreach of the Lower Arkansas River Basin from Arkansas River near Rocky Ford downstream to Arkansas River at Swink, Colorado, (A) 2009 and (B) 2010. 

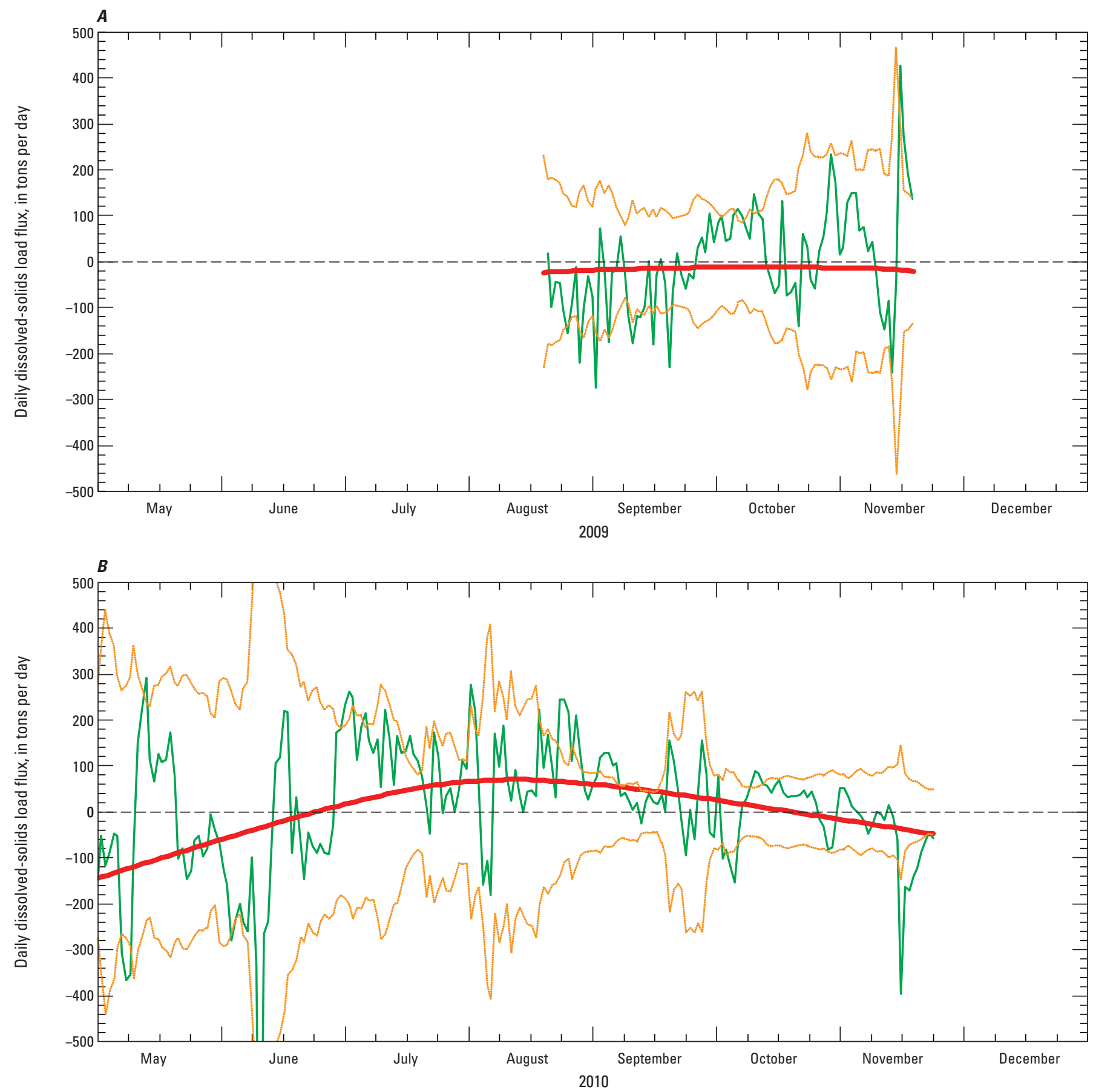

EXPLANATION

Dissolved-solids load flux

20-percent error bar-The averaged estimated daily dissolved-solids load of the upstream and downstream main-stem sites in the subreach

LOWESS smoothing curve

Figure 29. Estimated daily gains and losses in dissolved-solids load along a subreach of the Lower Arkansas River Basin from Arkansas River at Swink downstream to Arkansas River at La Junta, Colorado, $(A) 2009$ and $(B) 2010$. 

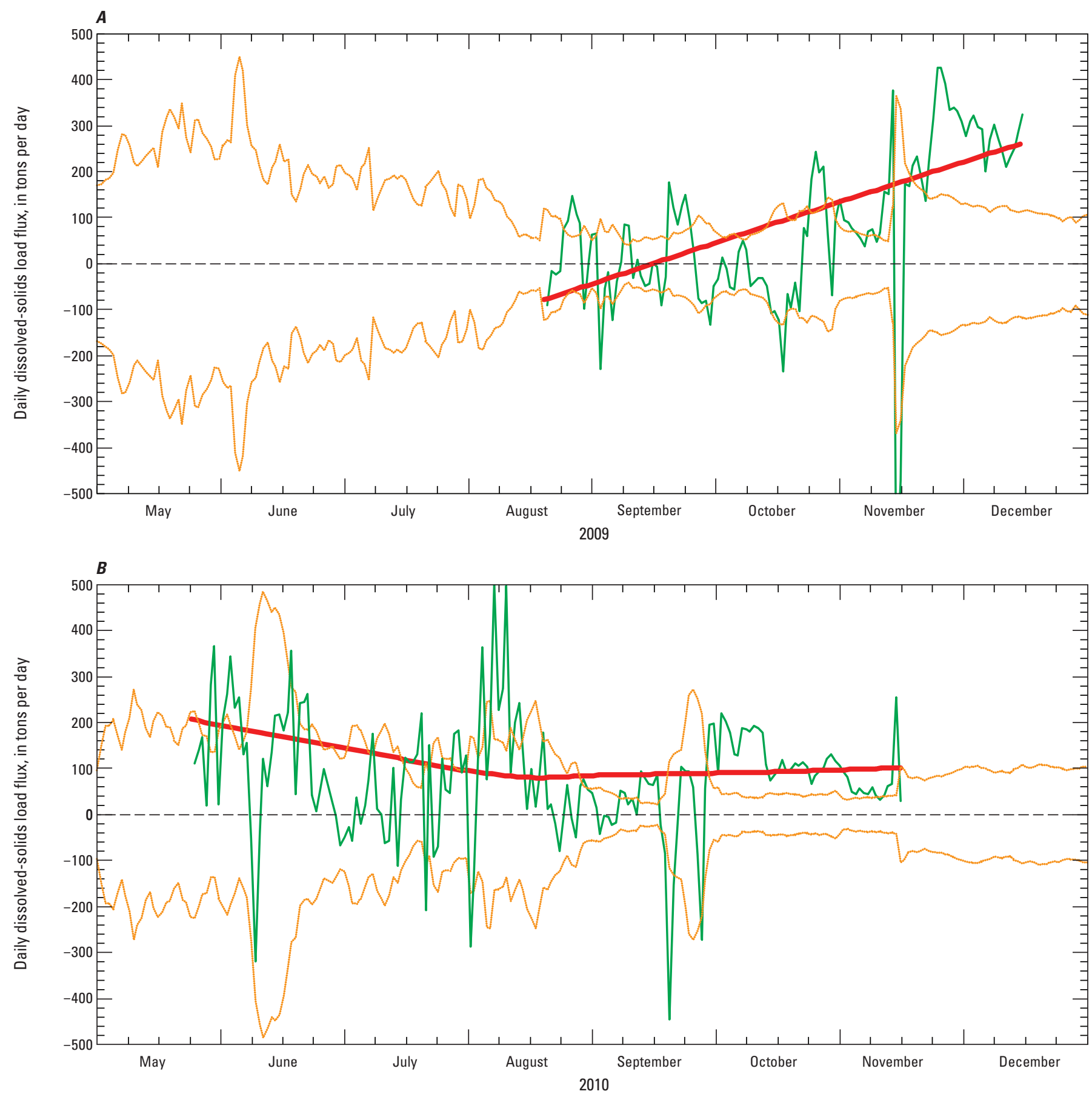

EXPLANATION

Dissolved-solids load flux

20-percent error bar-The averaged estimated daily dissolved-solids load of the upstream and downstream main-stem sites in the subreach

LOWESS smoothing curve

Figure 30. Estimated daily gains and losses in dissolved-solids load along a subreach of the Lower Arkansas River Basin from Arkansas River at La Junta downstream to Arkansas River at Las Animas, Colorado, $(A) 2009$ and $(B) 2010$. 
reach ended at La Junta. Identified tributaries along this reach include Horse Creek and Adobe Creek, which historically have high SC values and, potentially, could add substantial DS loads to the river. Miller and others (2010) reported that the median SC value for Horse Creek was 3,390 microsiemens per centimeter. The median $\mathrm{SC}$ value for 15 samples collected from Adobe Creek was 2,120 microsiemens per centimeter (U.S. Geological Survey, 2003). One large diversion ditch, the Las Animas Consolidated ditch, removes water from the river along this subreach and was not included in this analysis.

\section{Potential Unmeasured Sources and Sinks for Dissolved-Solids Load}

The results from the analyses of unmeasured sources and sinks of DS load, as described in the two previous sections of this report, indicated that potential source areas were identifiable in the study reaches. It might be expected that unmeasured DS load flux would be identified along the same reaches where unmeasured streamflow flux was identified. To that extent, some of the observed results from the analysis of daily DS loading did mirror the streamflow results. In some subreaches of the Arkansas River, however, unmeasured sources and sinks of DS load did not appear to be directly associated with unmeasured sources and sinks of streamflow.

In the UARB from Ark at Canon City to Ark nr Canon City, unmeasured gains in DS load were estimated to range from 11 to 22 tons per day per mile in 2009 and from 8 to 13 tons per day per mile in 2010 (fig. 22); streamflow from unmeasured sources was estimated to be about $20 \mathrm{ft}^{3} / \mathrm{s}$ per mile along this same reach. Downstream from this short reach, DS load to the river from unmeasured sources was estimated to range from 5.4 to 7.6 tons per day per mile in 2010 for Ark nr Canon City to Ark at Portland (fig. 23) and from 11 to 16 tons per day per mile in 2009 for Ark at Portland to Ark nr Portland (fig. 24). Gains from unmeasured sources of streamflow were not identified in either of these subreaches. Several small tributaries with DS concentrations ranging from $3,000 \mathrm{mg} / \mathrm{L}$ to as high as $6,000 \mathrm{mg} / \mathrm{L}$ enter the river along these subreaches. These inputs may indicate a potential source of groundwater that could affect DS loading in the river. Further investigation would be needed to identify the unmeasured source or sources of DS load to determine the nature and extent of unmeasured inputs.

In the LARB, gains in DS load from unmeasured sources were identified for the subreach from Ark nr Avondale to Ark at Nepesta although no substantial amounts of streamflow from unmeasured sources were identified for this subreach. In 2009, the estimated gain in DS load from unmeasured sources for this subreach was 4.7 tons per day per mile. An increase in DS load from unmeasured sources also was identified along the subreach of the river from Ark at Catlin to Swink (figs. 27 and 28); the DS load from unmeasured sources was estimated to range from 10 to 28 tons per day per mile. The only other river subreach where a gain in DS load from unmeasured sources was identified was from La Junta to Las Animas. Caution should be used interpreting these results because the focus of the data collection did not extend downstream from La Junta and some known inputs and diversions were not quantified.

The only loss of DS load was identified for the subreach from Nepesta to Catlin Dam in 2010 (fig. 26). The mechanism and spatial extent of the losses were not identified, and further investigation would be required to better understand the results.

\section{Summary}

The Arkansas River is an important municipal water supply and is the primary supply for about 400,000 acres of irrigated land in southeastern Colorado. The suitability of this water for domestic, agricultural, and industrial use is affected by high salinity in parts of the Arkansas River. Previous studies report that median specific-conductance (SC) values increased more than 6,000 percent from the headwaters to the Colorado-Kansas border; much of the increase occurred along the heavily irrigated areas from Canon City to Las Animas.

The Arkansas River Basin Regional Resource Planning Group (RRPG) adopted a strategy to address multiple waterquality concerns in the basin. The strategy included the need to quantify mass loading of dissolved solids (DS) in the Arkansas River to help identify stream reaches where stream-aquifer interactions have a pronounced effect on water quality in the river. In 2009, the U.S. Geological Survey (USGS), in cooperation with the RRPG and the Colorado Water Conservation Board, began a study to estimate gains and losses from unmeasured sources and sinks for streamflow and dissolved-solids load in selected reaches of the Arkansas River in southeastern Colorado. Data were collected during 2009-2010 to provide a basis for estimating the gains or losses for selected reaches from Canon City to Las Animas.

The purpose of this report is to describe estimates of gains and losses from unmeasured sources and sinks for streamflow and dissolved-solids load in the Arkansas River along two main study reaches. The estimates will help identify subreaches where gains or losses from unmeasured sources and sinks could have a pronounced effect on the water quality in the Arkansas River.

Streamflow data collected from established or seasonal (2009-2010) streamflow-gaging sites were analyzed to determine a reasonable water budget in selected reaches of the Arkansas River and to identify subreaches where gains or losses in streamflow from unmeasured sources may be occurring. SC and DS data were analyzed to derive estimates of daily DS concentrations at main-stem, tributary, and diversion sites. The results of these two analysis components were combined to derive a mass-load analysis that was applied at a subreach scale to help identify potential source areas of unmeasured DS loading in the river. 
For the purposes of this report, two main study reaches were selected for investigation. The first study reach includes the Arkansas River Basin from Canon City to just upstream from Pueblo Reservoir. This reach is identified as the Upper Arkansas River Basin (UARB) study reach. The second study reach is located downstream from Pueblo Reservoir and includes the Arkansas River Basin from Avondale to Las Animas. This reach is identified as the Lower Arkansas River Basin (LARB) study reach. In general, the data collected for this study can be categorized as either streamflow or water quality. Various types of data-collection methods were associated with each of these two categories. Streamflow data analyzed for this report consist primarily of daily streamflow records retrieved from established long-term streamflow sites or from seasonal gages installed and operated as part of this study. In some instances, estimated daily values were used in the analysis. Typically, daily streamflow data from established sites are published by either the USGS or the State of Colorado Division of Water Resources.

The water-quality data used in this report consisted of SC values from continuous-monitoring sites, periodic SC measurements at selected sites, and DS concentrations from water samples collected at numerous sites in the study reaches. Daily SC data were retrieved from USGS databases for continuous water-quality monitoring sites (established or seasonal) on the main stem of the Arkansas River. Periodic measurements of SC were available for all sites in both study reaches. Additionally, paired SC measurements and DS concentrations were available. As such, linear regression analyses to estimate DS concentrations from SC could be performed. Estimated DS concentrations combined with streamflow data could then be used to determine mass-loading characteristics in the study reaches.

Locally weighted scatterplot smoothing (LOWESS) techniques were used to evaluate gains or losses from unmeasured sources and sinks in daily streamflow and estimated daily DS load for selected sites in the Arkansas River. The smoothing technique describes the relation, in this instance, between streamflow and time or between DS and time without assuming linearity or normality of the residuals.

A common approach to investigating the flow of water from unmeasured sources or sinks is to measure streamflow at numerous points along a study reach to determine a water budget. These measurement points (sites) subdivide the stream into subreaches and accounts for inputs and outputs. The difference between inflows and outflows may be attributed to unmeasured sources or sinks, such as the interaction between the stream and the underlying aquifer. Given the other unmeasured components of error in this analysis, error bars of \pm 15 percent of the averaged daily streamflow of the upstream and downstream main-stem sites within a subreach were calculated to help evaluate the results. A value of \pm 15 percent was determined to be sufficiently conservative to allow for the identification of stream reaches where streamflow gains or losses exceeded the measurement error. Consistent exceedences of the error bars could potentially indicate stream reaches where surface-water inflows or groundwater inputs from unmeasured sources are a substantial part of the water budget.

In general, the methodology used to quantify streamflow water budgets along the UARB and LARB study reaches accounted for a large percentage of the streamflow. However, the results from the water-budget analyses indicated that potential areas of unmeasured sources and sinks of streamflow were identifiable in the two study reaches. Further investigations would be needed to better quantify the gains or losses and to determine the extent of unmeasured surfacewater or groundwater inputs, or both, to the river. In the UARB, a substantial volume of water in the subreach from Ark at Canon City to the seasonal USGS gaging station 5 miles downstream at Ark nr Canon City was unaccounted for by the methodology used in this analysis. The daily gain from unmeasured sources in this subreach was estimated to be about 100 cubic feet per second $\left(\mathrm{ft}^{3} / \mathrm{s}\right)$ or about $20 \mathrm{ft}^{3} / \mathrm{s}$ per river mile. Water-budget estimates for the remaining 18 miles of the UARB study reach indicated that gains or losses from unmeasured sources and sinks were within the measurement error as defined for this report.

In the LARB, the mechanisms and timing for diverting water from the river and for return flows to the river are inherently tied to the irrigation practices of the region. As such, a highly variable water budget was observed in this study reach as daily and even hourly changes in streamflow resulted from reservoir releases and demand for irrigation water. Gains and losses from unmeasured sources and sinks were identified in some of the subreaches but the magnitude of the streamflow flux generally was small. Unmeasured sources ranging from less than 2 to $3 \mathrm{ft}^{3} / \mathrm{s}$ per mile were identified in the river subreaches from Ark at Catlin Dam downstream to Ark at Swink. A streamflow loss (sink) was indicated along the subreach from Ark at Nepesta to Ark at Catlin Dam, particularly in 2010. The mechanism and spatial extent of this sink was not identified, and further investigation would be required to better quantify the losses.

The results from the analyses of unmeasured sources and sinks of DS load indicated that potential source areas were identifiable in the study areas. It might be expected that unmeasured DS load flux would be identified along the same reaches where unmeasured streamflow flux was identified. To that extent, some of the observed results from the analysis of daily DS loading did mirror the streamflow results. In some subreaches of the Arkansas River, however, unmeasured sources and sinks of DS load did not appear to be directly associated with unmeasured sources and sinks of streamflow.

In the UARB from Ark at Canon City to Ark nr Canon City, unmeasured gains in DS load were estimated to range from 11 to 22 tons per day per mile in 2009 and from about 8 to 13 tons per day per mile in 2010; streamflow from unmeasured sources was estimated to be about $20 \mathrm{ft}^{3} / \mathrm{s}$ per mile along this same reach. Downstream from this short reach, DS load to the river from unmeasured sources was estimated to range from 5.4 to 7.6 tons per day per mile in 
2010 for Ark nr Canon City to Ark at Portland and from 11 to 16 tons per day per mile in 2009 for Ark at Portland to Ark nr Portland. Unmeasured gains in streamflow were not identified in either of these subreaches. Several small tributaries with DS concentrations from 3,000 $\mathrm{mg} / \mathrm{L}$ to as high as $6,000 \mathrm{mg} / \mathrm{L}$ enter the river along these subreaches. These inputs may indicate a potential source of groundwater that could affect DS loading in the river. Further investigation would be needed to identify the unmeasured source or sources of DS load to determine the nature and extent of unmeasured inputs.

In the LARB, gains in DS load from unmeasured sources were identified for the subreach from Ark nr Avondale to Ark at Nepesta although no substantial amounts of streamflow from unmeasured sources were identified for this subreach. In 2009, the estimated gain in DS load from unmeasured sources for this subreach was 4.7 tons per day per mile. An increase in DS load from unmeasured sources also was identified along the subreach of the river from Ark at Catlin to Swink; the DS load from unmeasured sources was estimated to range from 10 to 28 tons per day per mile. The only loss of DS load was identified for the subreach from Nepesta to Catlin Dam in 2010. The mechanism and spatial extent of the losses were not identified, and further investigation would be required to better understand the results.

\section{Acknowledgments}

The authors would like to thank the many individuals who assisted in the collection and interpretation of data collected in support of this report. Thanks to Colorado Division of Water Resources Water Commissioners (Division 2) John Van Oort, Brian Sutton, Lonnie Spady, Charlie Judge (retired), and Don Taylor (retired) for providing timely responses to data requests. Thanks also to USGS personnel Robert Stogner, Sheryl Ferguson, Shaylynn Mincic, Pamela Tello, Crystal Brown, Ryan Kopp, Russ Lewins, and Brenden Ortiz (volunteer) for their tireless efforts collecting data.

\section{References Cited}

Cain, Doug, 1985, Quality of the Arkansas River and irrigation return flows in the lower Arkansas River valley, Colorado: U.S. Geological Survey Water-Resources Investigations Report 84-4273, 85 p.

Cain, Doug, 1987, Relations of specific conductance to streamflow and selected water-quality characteristics of the Arkansas River Basin, Colorado: U.S. Geological Survey Water-Resources Investigations Report 87-4041, 93 p.

Cleveland, W.S., 1979, Robust locally weighted regression and smoothing scatterplots: Journal of the American Statistical Association, v. 74, p. 829-836.
Cleveland, W.S., and Devlin, S.J., 1988, Locally weighted regression: An approach to regression analysis by local fitting: Journal of the American Statistical Association, v. 83 , p. $596-610$.

Colorado Decision Support System, 2011, Published monthly streamflow: Colorado Decision Support System Web site, accessed August 8, 2011, at http://cdss.state.co.us/ onlineTools/Pages/StreamflowStations.aspx.

Colorado Division of Water Resources, 2010, Cumulative yearly statistics of the Colorado Division of Water Resources-2009: Colorado Department of Natural Resources Web site, accessed February 23, 2011, at http:// water.state.co.us/DWRIPub/DWR\%20Annual\%20Reports/ CYS_rpt_2009.pdf.

Commonwealth of Australia, 2006, Connected waterManaging the linkages between surface water and ground water: Commonwealth of Australia Web site, accessed June 4, 2011, at http://www.connectedwater.gov.au/copyright. html.

Fishman, M.J., and Friedman, L.C., eds., 1989, Methods for determination of inorganic substances in water and fluvial sediments: U.S. Geological Survey Techniques of WaterResources Investigation, Book 5, Chapter Al, 545 p.

Helsel, D.R., and Hirsch, R.M., 1992, Statistical methods in water resources: U.S. Geological Survey Techniques of Water-Resources Investigations, Chapter A3, 510 p.

Ivahnenko, Tamara, Ortiz, Roderick, and Stogner, Robert, Sr., 2012, Characterization of streamflow, water quality, and instantaneous dissolved solids, selenium, and uranium loads in selected reaches of the Arkansas River Basin, southeastern Colorado, 2009-2010: U.S. Geological Survey Scientific Investigations Report 2012-5234, 60 p.

Lerner, D.N., Issar, A.S., and Simmers, Ian, 1990, Groundwater recharge - A guide to understanding and estimating natural recharge: Hannover, Germany, Heinz Heise, International Contributions of Hydrogeologists, v.8, $345 \mathrm{p}$.

Lewis, M.E., and Brendle, D.L., 1998, Relations of streamflow and specific-conductance trends to reservoir operations in the lower Arkansas River, southeastern Colorado: U.S. Geological Survey Water-Resources Investigations Report 97-4239, $48 \mathrm{p}$.

Lieberman, T.D., Middelburg, R.F., and Irvine, S.A., 1986, User's manual for estimation of dissolved-solids concentrations and load in surface water: U.S. Geological Survey Water-Resources Investigations Report 86-4124, 51 p.

Miles, D.L., 1977, Salinity in the Arkansas valley of Colorado: U.S. Environmental Protection Agency and Colorado State University, Interagency Agreement, EPAIAG- D4-0544, 80 p. 
Miller, L.D., Watts, K.R., Ortiz, R.F., and Ivahnenko, Tamara, 2010, Occurrence and distribution of dissolved solids, selenium, and uranium in groundwater and surface water in the Arkansas River Basin from the headwaters to Coolidge, Kansas, 1970-2009: U.S. Geological Survey Scientific Investigations Report 2010-5069, 59 p. (Also available at http://pubs.usgs.gov/sir/2010/5069/.)

Ortiz, R.F., 2004, Methods to identify changes in background water-quality conditions using dissolved-solids concentrations and loads as indicators, Arkansas River and Fountain Creek, in the vicinity of Pueblo, Colorado: U.S. Geological Survey Scientific Investigations Report 2004-5024, 20 p. (Also available at http://pubs.usgs.gov/ sir/2004/5024.)

Ortiz, R.F., Lewis, M.E., and Radell, M.J., 1998, Water-quality assessment of the Arkansas River Basin, southeastern Colorado, 1990-93: U.S. Geological Survey WaterResources Investigations Report 97-4111, 69 p.

Rantz, S.E., and others, 1982a, Measurement and computation of streamflow - v. 1, Measurement of stage and discharge: U.S. Geological Survey Water-Supply Paper 2175, 283 p. (Also available online at $h t t p: / / w a t e r . u s g s . g o v / p u b s / w s p /$ wsp2175; accessed July 21, 2011.)

Rantz, S.E., and others, 1982b, Measurement and computation of streamflow-v. 2, Computation of discharge: U.S. Geological Survey Water-Supply Paper 2175, 347 p. (Also available online at http://water.usgs.gov/pubs/wsp/wsp2175; accessed July 21, 2011.)

Southeastern Colorado Water Conservancy District, 2011, Winter water storage program: Southeastern Colorado Water Conservancy District Web site, accessed August 28, 2011, at http://www.secwcd.org/WinterWtr.htm.

U.S. Geological Survey, 2003, User's manual for the National Water Information System of the U.S. Geological Survey-Automated Data Processing System (ADAPS): U.S. Geological Survey Open-File Report 03-123 ver. 4.3, 407 p. (Also available at http://pubs.usgs.gov/of/2003/ ofr03123/; accessed October 10, 2011.)

U.S. Geological Survey, variously dated, National field manual for the collection of water-quality data: U.S. Geological Survey Techniques of Water-Resources Investigations, book 9, chaps. A1-A9. (Also available online at http://pubs.water. usgs.gov/twri9a.)

Wagner, R.J., Boulger, R.W., Jr., Oblinger, C.J., and Smith, B.A., 2006, Guidelines and standard procedures for continuous water-quality monitors-Station operation, record computation, and data reporting: U.S. Geological Survey Techniques and Methods 1-D3, 51 p. (Also available online at http://pubs.water.usgs.gov/tm 1d3; accessed October 10, 2011.)
Publishing support provided by:

Denver Publishing Service Center

For more information concerning this publication, contact: Director, USGS Colorado Water Science Center Box 25046, Mail Stop 415

Denver, CO 80225

(303) 236-4882

Or visit the Colorado Water Science Center Web site at: http://co.water.usgs.gov/

(303) 236-2000 


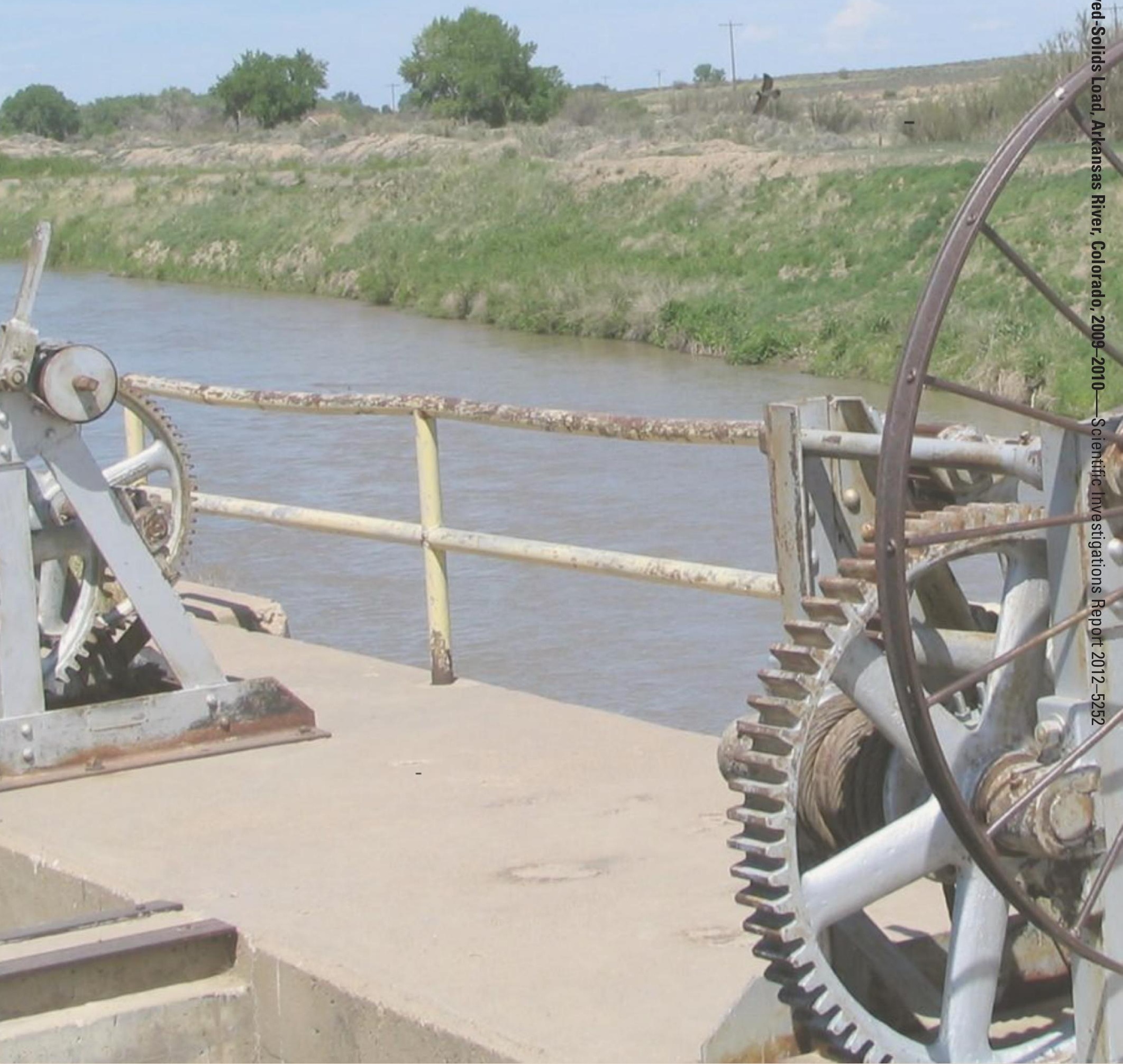

